


\section{Het meetbaar maken van natuurinclusieve economie}

Stijn Reinhard ${ }^{1}$, René Verburg ${ }^{1}$, Eveliene Steingröver², Vincent Linderhof ${ }^{1}$, Claire Vos ${ }^{2}$, Carla Grashof-Bokdam², Rolf Michels ${ }^{1}$

1 Wageningen Economic Research

2 Wageningen Environmental Research

Dit onderzoek is uitgevoerd door Wageningen Economic Research in opdracht van en gefinancierd door het ministerie van Economische Zaken, in het kader van het Beleidsondersteunend onderzoeksthema 'Meetbaar maken natuurinclusief en natuurcombinaties' (projectnummer BO-11-012-037)

Wageningen Economic Research

Wageningen, december 2016

RAPPORT

2016-077

ISBN 978-94-6343-033-3 
Stijn Reinhard, René Verburg, Eveliene Steingröver, Vincent Linderhof, Claire Vos,

Carla Grashof-Bokdam, Rolf Michels, 2016. Het meetbaar maken van natuurinclusieve economie.

Wageningen, Wageningen Economic Research, Rapport 2016-077. 58 blz.; 17 fig.; 12 tab.; 37 ref.

De Rijksnatuurvisie stelt dat door in economische processen anders om te gaan met leefomgeving en natuurlijke hulpbronnen, winst voor natuur kan worden geboekt. Hoe kan die 'winst voor natuur' worden gemeten? Door het meetbaar maken van de gevolgen van een natuurinclusieve economie, en meer specifiek het rendement dat dit voor de natuur levert, kan beleid gemonitord en aangepast worden.

According to the National Nature Vision (Rijksnatuurvisie), we can generate 'profit for nature' by taking a different view of the relationship between economic processes and the living environment and natural resources. The question is: how can this 'profit for nature' be measured? Quantifying the effects of a nature-inclusive economy and, more specifically, the beneficial returns that this produces for the environment will allow us to monitor and adapt government policies.

Trefwoorden: Rijksnatuurvisie, natuurinclusieve economie, natuurinclusief ondernemen, raamwerk, effecten

Dit rapport is gratis te downloaden op http://dx.doi.org/10.18174/399872 of op www. wur. nl/economic-research (onder Wageningen Economic Research publicaties).

(C) 2016 Wageningen Economic Research

Postbus 29703, 2502 LS Den Haag, T 07033583 30, E communications.ssg@wur.nl, www. wur.nl/economic-research. Wageningen Economic Research is onderdeel van Wageningen University \& Research.

\section{(cc) BY-NC}

Wageningen Economic Research hanteert voor haar rapporten een Creative Commons Naamsvermelding 3.0 Nederland licentie.

(c) Wageningen Economic Research, onderdeel van Stichting Wageningen Research, 2016 De gebruiker mag het werk kopiëren, verspreiden en doorgeven en afgeleide werken maken. Materiaal van derden waarvan in het werk gebruik is gemaakt en waarop intellectuele eigendomsrechten berusten, mogen niet zonder voorafgaande toestemming van derden gebruikt worden. De gebruiker dient bij het werk de door de maker of de licentiegever aangegeven naam te vermelden, maar niet zodanig dat de indruk gewekt wordt dat zij daarmee instemmen met het werk van de gebruiker of het gebruik van het werk. De gebruiker mag het werk niet voor commerciële doeleinden gebruiken.

Wageningen Economic Research aanvaardt geen aansprakelijkheid voor eventuele schade voortvloeiend uit het gebruik van de resultaten van dit onderzoek of de toepassing van de adviezen.

Wageningen Economic Research is ISO 9001:2008 gecertificeerd.

Wageningen Economic Research Rapport 2016-077 | Projectcode 2282700237

Foto omslag: Shutterstock 


\section{Inhoud}

Woord vooraf $\quad 5$

$\begin{array}{ll}\text { Samenvatting } & 6\end{array}$

$\begin{array}{ll}\text { Summary } & 7\end{array}$

1

$\begin{array}{ll}\text { Inleiding } & 8\end{array}$

1.1 Introductie $\quad 8$

1.2 Probleemstelling 8

1.3 Randvoorwaarden/wensen meetbaar maken 9

$\begin{array}{lll}1.4 & \text { Methode } & 9\end{array}$

$\begin{array}{ll}\text { Natuurinclusieve economie } & 10\end{array}$

$2.1 \quad$ Natuurlijk kapitaal, ecosysteemdiensten en biodiversiteit $\quad 10$

$\begin{array}{lll}2.2 & \text { Ecosysteemdiensten } & 14\end{array}$

2.3 Meetbaar maken ecosysteemdiensten en natuurlijk kapitaal 16

2.3.1 Ecosysteemdiensten 16

$\begin{array}{ll}\text { 2.3.2 Natuurlijk kapitaal } & 17\end{array}$

2.4 Meetbaar maken van relatie bedrijven met natuur $\quad 18$

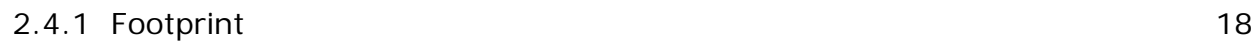

2.4.2 Jaarrapportage en milieurekeningen 18

2.4.3 Keurmerken $\quad 19$

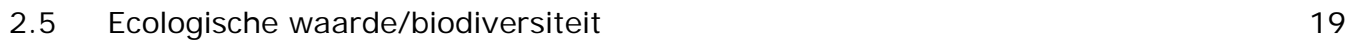

$\begin{array}{lll}2.6 & \text { Synthese } & 20\end{array}$

$\begin{array}{lr}\text { Generiek raamwerk } & 22\end{array}$

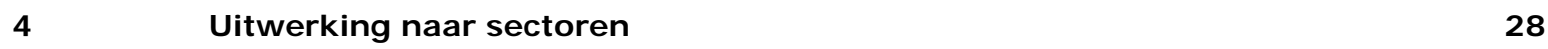

$\begin{array}{lll}4.1 & \text { Landbouw } & 29\end{array}$

4.1.1 Keurmerk Blief 29

4.1.2 Maatregelen in het keurmerk 29

4.1.3 Analyse Bliefmaatregelen 30

4.1.4 Meetbaarheid van effecten maatregelen 32

4.1.5 Conclusie 33

$\begin{array}{lll}4.2 & \text { Gastvrijheidsector } & 33\end{array}$

4.2.1 Keurmerk Green Key 33

4.2.2 Maatregelen keurmerk Green Key 34

4.2.3 Analyse maatregelen Green Key $\quad 35$

4.2.4 Meetbaarheid effecten maatregelen 37

4.2.5 Conclusie 38

$\begin{array}{lll}4.3 & \text { Bouw (BREEAM-NL) } & 39\end{array}$

4.3.1 Keurmerk BREEAM-NL 39

$\begin{array}{ll}\text { 4.3.2 Maatregelen } & 40\end{array}$

4.3.3 Analyse maatregelen BREEAM $\quad 41$

4.3.4 Meetbaarheid van effecten maatregelen 44

4.3.5 Conclusie $\quad 46$

$\begin{array}{lll}4.4 & \text { Synthese } & 46\end{array}$ 
$\begin{array}{lll}5.1 & \text { Conclusies } & 48\end{array}$

$\begin{array}{lll}5.2 & \text { Aanbevelingen } & 49\end{array}$

$\begin{array}{ll}\text { Literatuur en websites } & \mathbf{5 0}\end{array}$

$\begin{array}{lll}\text { Bijlage } 1 & \text { Ecosysteemdiensten Atlas Natuurlijk Kapitaal }\end{array}$

Bijlage 2 Graadmeters ecosysteemdiensten uit de Knegt et al. (2014) 56 


\section{Woord vooraf}

In opdracht van het ministerie van EZ heeft Wageningen Economic Research samen met Wageningen Environmental Research onderzocht hoe de effecten van natuurinclusieve economie op natuur meetbaar kunnen worden gemaakt.

De Rijksoverheid heeft de ambitie dat economische en andere activiteiten (zoals recreatie, consumptie en zorg) zo veel mogelijk 'natuurinclusief' worden (verwoord in de Rijksnatuurvisie 'Natuurlijk Verder'). Dat wil zeggen dat natuur in denken, beslissen en doen wordt meegenomen, zowel bij bedrijven, als burgers, overheden en NGO's. Onder het motto 'meten is weten' is het meetbaar maken van natuurinclusieve economie belangrijk voor het beleid.

Bedrijven maken hun duurzaamheidsprestaties steeds meer kwantitatief en openbaar. Daarnaast maken onderzoeksinstellingen en natuurorganisaties ook veel informatie over milieudruk en natuur breed beschikbaar. In deze rapportage is aan de hand van een ontwikkeld natuurinclusief raamwerk geanalyseerd hoe al deze beschikbare informatie op elkaar aansluit en wat er nog mist aan gegevens.

Keurmerken kunnen natuurinclusieve criteria opnemen in hun criteria en daarmee natuurinclusieve economie stimuleren. Keurmerkhouders vormen een bron van kwantitatieve informatie over natuurinclusieve activiteiten die bedrijven nemen. In dit rapport zijn enkele keurmerken onder de loep genomen.

I k wil graag de EZ begeleidingscommissie bedanken voor hun inbreng, waardoor het rapport is verbeterd: Patricia Braaksma (voorzitter), J oop van Bodegraven, Martin Lok en Hans Rutten.

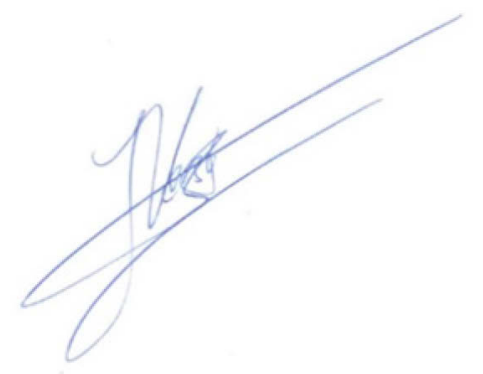

Prof.dr.ir. Jack (J.G.A.J .) van der Vorst Algemeen Directeur Social Sciences Group Wageningen University \& Research 


\section{Samenvatting}

Om effecten van beleid dat natuurinclusieve economie stimuleert (onder andere Rijksnatuurvisie) meetbaar te maken, is een door de stakeholders gedragen raamwerk (beleidstheorie) nodig. Een raamwerk om natuurinclusieve economie meetbaar te maken is ontwikkeld. Een eenvoudige versie van het raamwerk kan worden gebruikt in communicatie met stakeholders. Een meer gedetailleerde versie geeft de indicatoren weer die worden gemeten.

Natuurinclusieve economie kan op bedrijfsniveau worden gemeten en geaggregeerd naar een hoger - voor natuur relevant - schaalniveau. Om de effecten op natuur in Nederland te kunnen meten is het bedrijfs-/landschapsniveau het relevante schaalniveau waarop aantalsontwikkelingen van soorten kunnen worden gemonitord.

Er wordt al gemeten en gerapporteerd over deelrelaties tussen natuur en economie. Zo rapporteren met name grotere bedrijven over hun duurzaamheidsprestaties en wordt de aanwezigheid van een aantal plant- en diersoorten geteld. De metingen van bedrijven en van ecologen zijn (nog) niet eenvoudig aan elkaar te koppelen, waardoor het niet mogelijk is om na te gaan wat het effect van natuurinclusieve economie op natuur is.

Duurzaamheidskeurmerken kunnen bron van informatie zijn Houders van duurzaamheidskeurmerken kunnen een goede informatiebron zijn voor effecten van natuurinclusieve economie, als ze bovenwettelijke eisen stellen ten aanzien van natuur. Deze eisen moeten kwantitatief worden gemaakt om het effect van de bijbehorende maatregelen te kunnen meten. Nu zijn criteria soms te algemeen geformuleerd om effecten meetbaar te kunnen maken.

Indicatoren

Het effect van activiteiten op natuur en milieu wordt in duurzaamheidsrapportages van bedrijven weergegeven aan de hand van indicatoren die het bedrijf al voorhanden heeft (gebruik van grondstoffen en productiemiddelen), deze worden gerelateerd aan natuur. Grote ondernemingen met een GRI4 duurzaamheidsrapportage rapporteren op de schaal van hun hele onderneming (wereldschaal) en niet separaat voor de vestigingen.

Regionale samenwerking

Om natuureffecten op landschapsniveau te bereiken, is regionale samenwerking van partijen belangrijk om gunstige milieu- en habitatcondities op dat schaalniveau te garanderen;

\section{Methode}

In de Rijksnatuurvisie spreekt de Rijksoverheid de ambitie uit dat activiteiten steeds meer 'natuurinclusief' worden. Om de effecten van deze 'natuurinclusieve economie' beter te kennen, hebben Wageningen Economic Research en Wageningen Environmental Research (beide onderdeel van Wageningen UR) in opdracht van het ministerie van Economische Zaken onderzocht hoe de bijdrage van natuurinclusieve economie op natuur kan worden gemeten.

\section{Generiek naar sectorspecifiek}

Een praktisch raamwerk is ontwikkeld om de relatie tussen natuur en economie te concretiseren. Om dit toe te passen in de praktijk, moet het generieke raamwerk sectorspecifiek worden gemaakt. Met keurmerkhouders is geanalyseerd welke gegevens zij voor handen hebben om kwantitatieve uitspraken te kunnen doen over de impact van natuurinclusieve economie op natuur. 


\section{Summary}

Measuring the impact of policy designed to encourage a nature-inclusive economy (such as the 'The Natural Way Forward: Government Vision 2014') requires a framework (policy theory) that enjoys broad support from the stakeholders involved. A framework has been developed that enables us to measure the effects of a nature-inclusive economy. A simpler version of this framework can be used when communicating with stakeholders, while a more detailed version lists the indicators to be measured.

A nature-inclusive economy can be measured at business level and then aggregated at a higher scale level that is relevant for nature. The business and landscape levels are the applicable scale levels used to measure the effects on nature in the Netherlands. Among other things, these levels enable us to monitor abundance trends of species.

Sub-relationships between nature and the economy are already being monitored and reported on. Larger companies in particular employ monitoring and reporting to communicate their sustainability performance, and several plant and animal species are being counted. It is not yet possible to link the measurements being taken by the business sector with those performed by ecologists. As such, we are unable to determine the impact of a nature-inclusive economy on nature.

Quality certificates for sustainability can serve as sources of information Organisations that award quality certificates for firms' sustainability can provide a wealth of information about the effects of a nature-inclusive economy, if they have established supra-statutory requirements for the environment. These requirements must be quantifiable in order to measure the impact of associated measures. At present, the criteria are sometimes too generically formulated to be able to measure the effects of a nature-inclusive economy.

Indicators

To demonstrate the impact of their daily operations on nature and the environment, businesses publish sustainability reports containing indicators that are readily available to them, such as the use of natural resources and the means of production. These indicators are then related to nature. Major companies that produce GRI G4 reporting provide information on the scale of their entire operation, meaning globally, rather than for each individual branch.

Regional cooperation

Regional cooperation between parties is important if effects on nature in a given landscape are to be achieved, as only then can beneficial environmental and habitat conditions be guaranteed at within this level.

\section{Method}

'The Natural Way Forward: Government Vision 2014'expresses the national government's ambition for business and private activities to become ever more 'nature-inclusive'. To better understand the impact of the 'nature-inclusive economy,' the Dutch Ministry of Economic affairs requested that Wageningen Economic Research and Wageningen Environmental Research, divisions of Wageningen UR, conduct research on how to measure the impact of the nature-inclusive economy on the environment.

From general to sector-specific frameworks

A practical framework has been developed to concretise the relationship between nature and the economy. However, before it can be put into practice, this general framework must be made sector specific. Researchers at Wageningen have analysed which of the data that is readily available to holders of sustainability certificates can be used to make quantitative statements about the impact of a nature-inclusive economy on the environment. 


\section{$1 \quad$ Inleiding}

\section{$1.1 \quad$ Introductie}

Natuur en economie kunnen elkaar versterken, aldus de Rijksnatuurvisie 'Natuurlijk Verder' (EZ, 2014). De ambitie is dat economische en andere activiteiten (zoals recreatie, consumptie en zorg) zo veel mogelijk 'natuurinclusief' worden, dus zoveel mogelijk met natuur worden vervlecht. Dat wil zeggen dat natuur in denken, beslissen en doen wordt meegenomen, zowel bij bedrijven, als burgers, overheden en NGO's. Een natuurinclusieve economie gaat daarom om het duurzaam gebruik van de natuur en natuurlijke hulpbronnen. In een natuurinclusieve economie participeren burgers, bedrijven en maatschappelijke organisaties ook in de financiering van natuur.

Het meetbaar maken van de gevolgen van een natuurinclusieve economie, en meer specifiek het rendement dat dit levert, is belangrijk. Hiermee kan beleid gemonitord en aangepast worden. Het meten kan bijdragen aan een aantal doelstellingen:

1. Door natuurinclusieve economie meetbaar te maken, verkrijgen we inzicht in het effect ervan. Positieve effecten kunnen beter worden gecommuniceerd. Dit kan een versterkend effect hebben op het uitdragen van nieuwe natuurinclusieve projecten door bedrijven en burgers. Negatieve effecten zullen aanleiding (kunnen) zijn voor een beleidsinspanning van de overheid;

2. Het meetbaar maken kan bijdragen aan betere ex-ante evaluaties van toekomstige projecten en beleid, waarmee projecten en beleid doelmatiger kunnen worden uitgevoerd.

\subsection{Probleemstelling}

De Rijksnatuurvisie stelt dat door in economische processen anders om te gaan met leefomgeving en natuurlijke hulpbronnen, winst voor natuur kan worden geboekt. Het gaat dan niet om 'minder schade aan natuur', maar om 'meer winst voor natuur', bijvoorbeeld meer natuurhectares, hogere biodiversiteit, enzovoort. Onderwerp van dit onderzoek is hoe die 'winst voor natuur' kan worden gemeten.

De praktijk van natuurinclusieve economie is nog onvoldoende (kwantitatief) bekend. Daardoor is het nog niet mogelijk om te bepalen of (en zo ja in hoeverre) natuur rendeert door natuurinclusieve economie, waaronder ook natuurcombinaties met andere landgebruiksfuncties worden gerekend (Fontein et al., 2015). Als deze kennis beschikbaar komt kan het raamwerk, dat het effect van natuurinclusieve economie op natuur beschrijft, verder worden uitgewerkt.

In dit rapport worden de volgende drie vragen beantwoord:

a. Wat is de essentie van een natuurinclusieve economie die meetbaar moet worden gemaakt:
a. Wat is het relevante natuurbegrip?
b. Wat wordt er al meetbaar gemaakt?
c. Welke indicatoren worden gebruikt?

b. Hoe kan de relatie tussen natuur en economie worden uitgewerkt in de beleidstheorie?

c. Hoe kan het effect van maatregelen, die de relatie tussen natuur en economie (positief) beïnvloeden, worden gemeten? 


\subsection{Randvoorwaarden/wensen meetbaar maken}

$\mathrm{Er}$ is al veel geschreven over de relatie tussen natuur en economie. We vatten enkele belangrijke en veelgebruikte concepten samen uit de bestaande literatuur. Bij deze selectie is de Rijksnatuurvisie leidend. Ook is met betrokken beleidsmedewerkers overlegd hoe knopen met betrekking tot definities en methoden worden doorgehakt, zoals:

- De Rijksnatuurvisie bakent natuur niet strikt af tot Nederland (hoewel daar wel de nadruk op ligt). Om concreet te kunnen meten aan de effecten van een natuurinclusieve economie op natuur, focussen we op natuur in Nederland. Zo kan bijvoorbeeld het aantal soorten of nieuwe oppervlakte natuur daadwerkelijk worden gemonitord. Het te ontwikkelen raamwerk kan ook worden gebruikt voor natuur buiten de landsgrenzen.

- Het gaat om natuur/ecosystemen in de brede zin en is niet ingeperkt tot biodiversiteit.

- Voorkeur om de ontwikkeling van natuur in de tijd te meten.

- Sectorgewijze voorbeelden, om een beeld te schetsen wat er mogelijk is (of al gebeurt) in een sector:

- De methode om inzicht te bieden in natuurinclusieve economie moet de mogelijkheid bieden om beleid te evalueren;

- Waar mogelijk aansluiten bij instrumenten waarbij EZ een rol kan spelen: subsidies, beprijzen van externe effecten, stimulerende instrumenten (communicatie); kennisinstrumenten via green deals en groene tafels, enzovoort;

- Er is nog geen (kwantitatief) beleidsdoel voor natuurinclusieve economie geformuleerd dat als indicator kan dienen voor beleidsinspanningen op dit terrein (zie paragraaf 1.1).

We concentreren ons in dit rapport (eerst) op het meten van het directe effect van natuurinclusieve economie op natuur. In een volgende stap kunnen de indirecte effecten ook worden beschouwd. Effecten die bijvoorbeeld via de productketen doorwerken worden wel benoemd, maar niet expliciet kwantitatief meegenomen in het te ontwikkelen raamwerk.

\section{$1.4 \quad$ Methode}

De Rijksnatuurvisie beoogt met een natuurinclusieve economie ervoor te zorgen dat bedrijven, die natuur gebruiken of er impact op hebben met hun productieproces, deze natuur duurzaam in stand houden of zelfs versterken. Daarom concentreren we ons in dit rapport op de relatie tussen natuur en bedrijven. We gebruiken daarom het 'brede natuurbegrip', wat verder gaat dan biodiversiteit (zie paragraaf 2.1). Voor het concept natuurinclusieve economie wordt een raamwerk ontwikkeld waarin bedrijven een centrale rol spelen. Om het effect van beleid na te kunnen gaan, wordt gebruik gemaakt van de beleidsevaluatie methodologie (COM, 2006). Aan de hand van de evaluatiemethodologie worden indicatoren benoemd die de relevante relaties (tussen de onderdelen van de beleidstheorie) beschrijven. Met bestaande methoden om de relatie tussen natuur en economie te meten, worden indicatoren geselecteerd die de ontwikkeling van natuurinclusieve economie meten. Outcomeindicatoren (die de bijdrage aan het beleidsdoel meten) zijn er niet, omdat er (nog) geen kwantitatieve beleidsdoelen zijn gesteld.

Om de ontwikkeling van natuur in de tijd te meten is een gestandaardiseerde meting nodig die wordt herhaald. Als wordt aangesloten bij initiatieven die al lopen, waarin natuurinclusieve economie wordt gemeten, is er al een begin van een tijdreeks. 


\section{$2 \quad$ Natuurinclusieve economie}

\subsection{Natuurlijk kapitaal, ecosysteemdiensten en biodiversiteit}

Definities

Ecosysteemdiensten zijn de sociaaleconomische functies van natuur die bedrijven (en andere landgebruikers) aanwenden voor hun productieproces. Natuurinclusieve economie kunnen we vertalen als het duurzaam gebruik van ecosysteemdiensten door bedrijven. De ecosysteemdiensten worden geleverd door het natuurlijk kapitaal (zie figuur 2.1). Natuurlijk kapitaal wordt beschouwd als een voorraad (Ecosystems assets in figuur 2.1), die de stroomgrootheid (Ecosystemservice flow in figuur 2.1) ecosysteemdiensten levert. Bij duurzaam gebruik van ecosysteemdiensten wordt het natuurlijk kapitaal niet uitgeput: de natuurlijke aanwas is in balans met de onttrekking voor consumptie. Natuurlijk kapitaal wordt onderscheiden in een abiotisch deel (de linker twee blauwe kolommen) en een biotisch deel (de rechter twee groene kolommen) in figuur 2.1. In deze studie richten we ons primair op de interactie tussen bedrijven en natuur en daarmee op het biotische deel, conform de (impliciete) afbakening in de Rijksnatuurvisie. Natuurlijk spelen abiotische elementen wel een belangrijke rol in de kwaliteit van het biologische deel.

\section{Components of Natural Capital:}

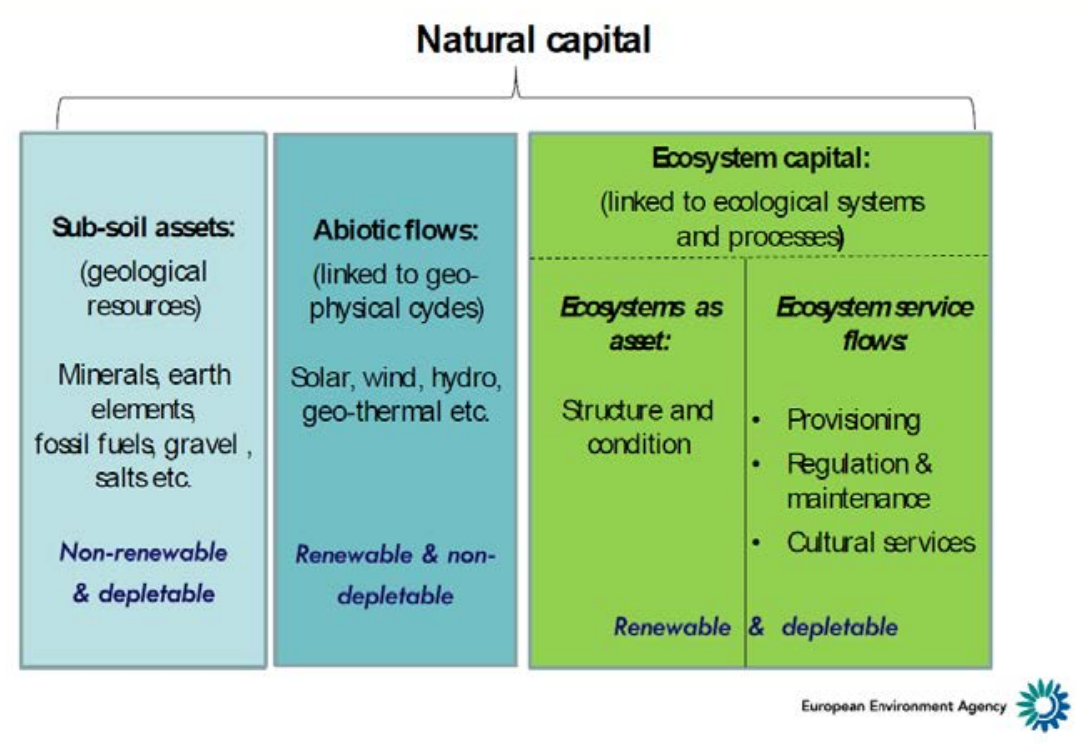

Figuur 2.1 Relatie tussen natuurlijk kapitaal, ecosysteemdiensten en impact van bedrijven Bron: Maes et al. (2013), gebaseerd op EEA.

Ecosysteemdiensten en abiotische diensten

De impact van het menselijke handelen (de economie) op het milieu en het natuurlijk kapitaal heeft invloed op de voorraad natuurlijk kapitaal. Figuur 2.2 geeft de relaties weer tussen natuurlijk kapitaal, ecosysteemdiensten, bedrijven en andere vormen van kapitaal. Bedrijven en kapitaal zijn afhankelijk van de ecosysteemdiensten en abiotische diensten die natuurlijk kapitaal leveren (Spurgeon, 2014). In deze benadering wordt onderscheid gemaakt tussen ecosysteemdiensten en abiotische diensten (abiotic flows in figuur 2.1). Bedrijven veroorzaken verschillende effecten op de omgeving, die het natuurlijk kapitaal en andere bedrijven (en andere kapitaalgoederen) beïnvloeden. Deze effecten 
worden externe effecten genoemd. Deze externe effecten op de omgeving kunnen zowel positief als negatief zijn. In de economische wetenschap zijn externe effecten onderdeel van de economie. Bedrijven beschouwen deze effecten niet als onderdeel van de economie. Bij een natuurinclusieve economie zullen externe effecten verminderen (ze worden geïnternaliseerd).

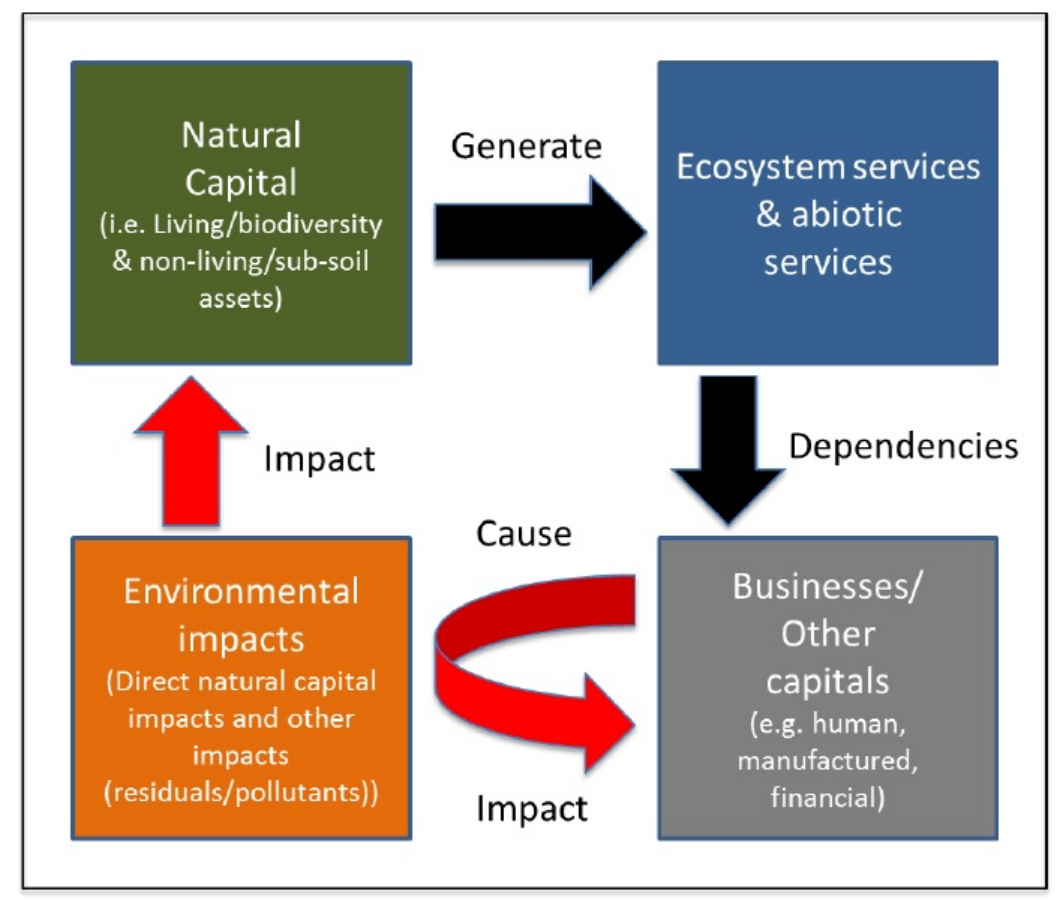

Figuur 2.2 De samenhang tussen natuurlijk kapitaal, ecosysteemdiensten, bedrijven en omgeving Bron: Spurgeon (2014).

Biodiversiteit

Naast de ecosysteemdiensten wordt biodiversiteit onderscheiden. Onder biodiversiteit wordt de verscheidenheid aan soorten verstaan: het aantal soorten in een gebied. Vaak is hier ook de verdeling van het aantal individuen van belang: een 'algemene soort' heeft veel individuen, een zeldzame soort weinig. Hiervoor worden in het beleid onder andere de 'Rode lijsten' voor gebruikt. Bij biodiversiteit is het dus van belang een 'gebied' te definiëren.

Analytisch raamwerk voor ecosystemen en ecosysteemdiensten Het EU MAES-project (Mapping and Assessment of Ecosystems and their Services) heeft tot doel om een analytisch raamwerk op te stellen, zodat de lidstaten de staat van hun ecosystemen en ecosysteemdiensten in kaart kunnen brengen en beoordelen (conform action 5 van de EU Biodiversity Strategy to 2020). In dit project bouwen ze voort op het werk van Haines-Yong en Potschin (2013). Maes et al. (2013) onderscheiden 'ecosystem functions', die de capaciteit van het systeem weergeven om ecosysteemdiensten te leveren (dus een onderdeel van natuurlijk kapitaal). Biodiversiteit is een onderdeel van het ecosysteem, zie figuur 2.3. Ecosysteemdiensten geven de gerealiseerde stroom van diensten weer, waarnaar vraag is. De mens (in het rechterdeel van figuur 2.3, 'socio-economic systems') ontleent baten aan de ecosysteemdiensten en hecht daar een waarde aan (het is niet mogelijk om de waarde van alle diensten in euro's uit te drukken). Het 'socio-economic system' beïnvloedt ook het ecosysteem. 


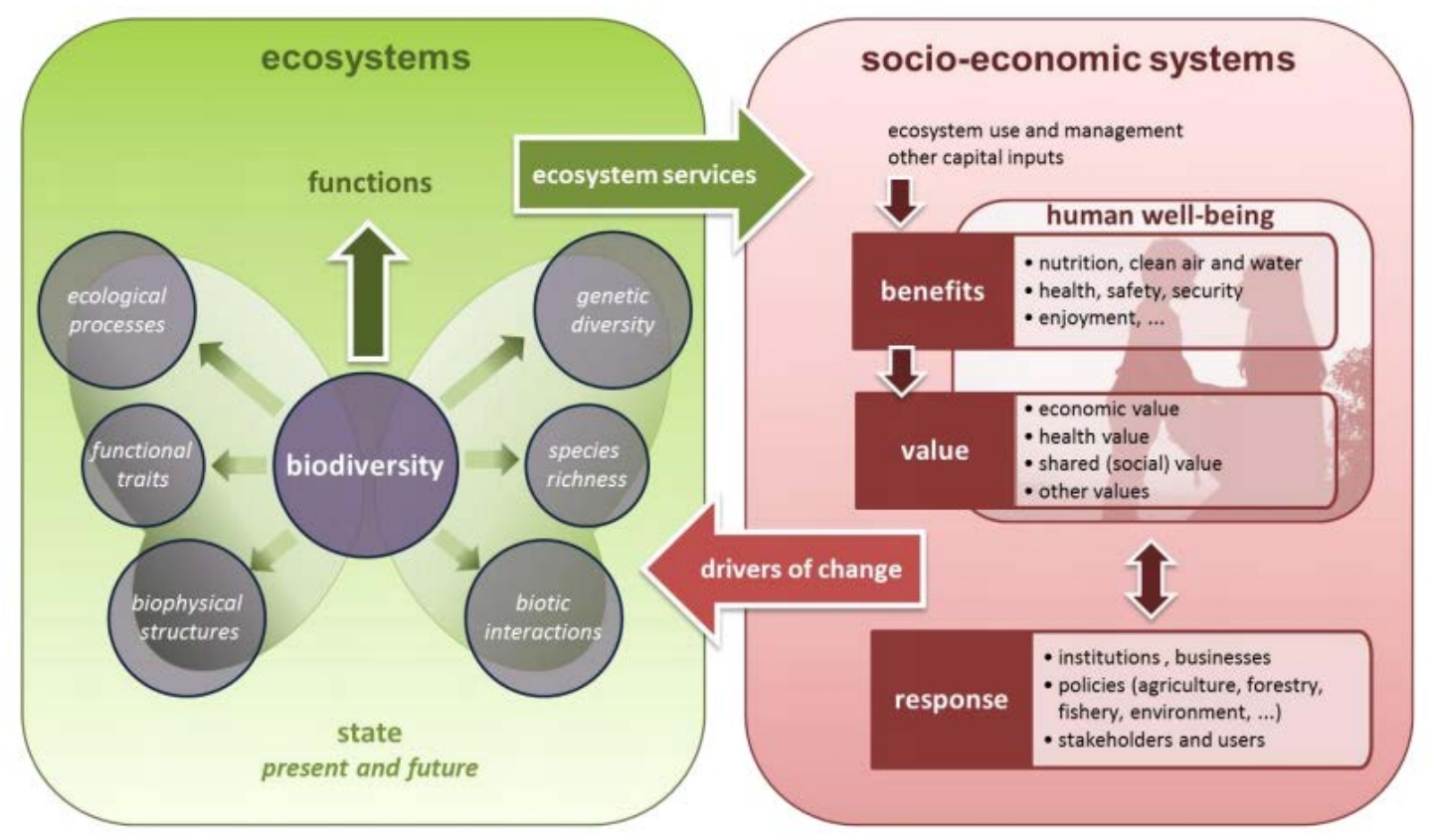

Figuur 2.3 Raamwerk dat samenhang tussen ecosystemen, ecosysteemdiensten en socioeconomisch systeem weergeeft Bron: Maes et al. (2013).

Ook in het OpenNess project (OpenNess, 2014) worden deze relaties uitgewerkt, zie figuur 2.4. In deze figuur is beleid toegevoegd om de negatieve impact van economisch handelen te verminderen.

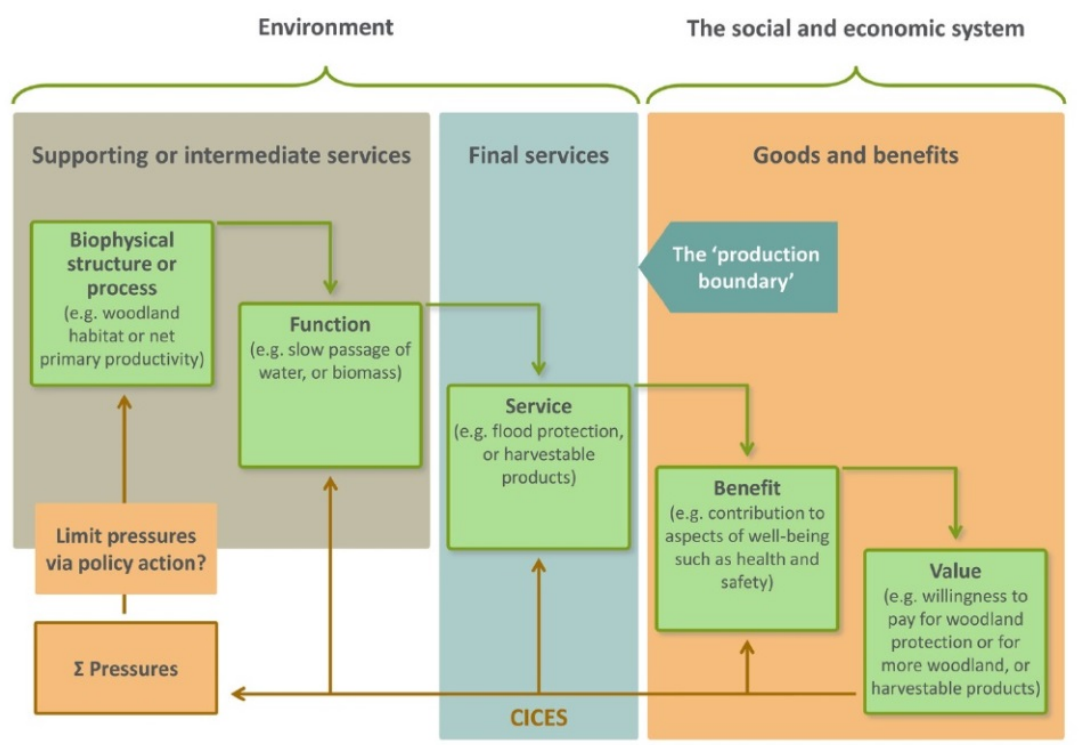

Figuur 2.4 Raamwerk dat samenhang tussen ecosystemen, ecosysteemdiensten en socio-economic systems weergeeft. CICES staat voor Common International Classification of Ecosystem Services Bron: OpenNess (2014); Haines-Yong en Potschin (2013).

Van het bondig literatuuroverzicht nemen we in ieder geval over dat economische activiteiten ten minste drie verschillende relaties met natuur en biodiversiteit hebben:

i. Economische activiteiten maken gebruik van de ecosysteemdiensten van natuur. Dit kan indirect (bijvoorbeeld regulerende functies van natuur als waterzuivering, bestuiving enzovoort) 
en direct gebruik zijn (bijvoorbeeld productiegoederen van natuur als hout, vis, enzovoort). Dit gebruik van natuur wordt aangeduid als afhankelijkheid van bedrijven van natuur. Dit wordt 'dependency' genoemd in het Natural Capital protocol (NCC, 2015).

ii. Economische activiteiten kunnen een effect hebben op natuur (zowel een negatief als een positief effect is mogelijk). Dit wordt 'impact' genoemd in het Natural Capital protocol (NCC 2015). Emissies zoals stikstof, fosfaat, $\mathrm{CO}_{2}$ en dergelijke hebben direct en indirect invloed op de (kwaliteit van de) natuur. Met name de soortsamenstelling (en daarmee biodiversiteit) is hiervoor gevoelig.

iii. Daarnaast leidt het onttrekken van hulpbronnen/grondstoffen, zoals water, tot negatieve effecten. Andere effecten zijn het onttrekken van areaal.

Homogene groepen

Op basis van deze drie relaties die bedrijven met natuur en biodiversiteit kunnen hebben, kunnen bedrijven in (meer homogene) groepen worden ingedeeld (Bouma en Leenders, 2013). Aan hun indeling in drie groepen, hebben we er één toegevoegd (type IV) die (nagenoeg) geen directe interactie heeft met natuur. De verschillen tussen de typen I-IV worden vooral bepaald door de mate van afhankelijkheid en tussen vermijden van effecten en het nemen van maatregelen om de natuur te versterken.

Tabel 2.1 Bedrijfstypen en relatie met natuur

\begin{tabular}{|c|c|c|c|c|}
\hline & Type I & Type II & Type III & Type IV \\
\hline $\begin{array}{l}\text { Voornaamste reden } \\
\text { van bedrijf van } \\
\text { aandacht voor } \\
\text { natuur }\end{array}$ & $\begin{array}{l}\text { Zekerstellen } \\
\text { bedrijfsproces }\end{array}$ & $\begin{array}{l}\text { Reputatie effect en } \\
\text { zekerstellen } \\
\text { bedrijfsproces }\end{array}$ & Licence to operate & $\begin{array}{l}\text { Maatschappelijk } \\
\text { verantwoord ondernemen }\end{array}$ \\
\hline
\end{tabular}

Bron: Bouma en Leenders (2013); aanvulling door auteurs.

Een vergelijkbare indeling is gemaakt door World Business Council for Sustainable Development (WBCSD, 2011). Zij onderscheiden:

- bedrijven afhankelijk van ecosysteemdiensten (bijvoorbeeld visserij, landbouw en bosbouw)

- grote-'footprint'-bedrijven (bijvoorbeeld mijnbouw, olie en gas, bouwbedrijven)

- maak- en procesindustrie (bijvoorbeeld chemie, ICT, consumer products)

- groene ondernemingen (bijvoorbeeld biologische landbouw en ecotoerisme)

- financiële dienstverlening (bijvoorbeeld banken, verzekeraars en andere financiële intermediairs)

Van ieder van deze type bedrijven geeft de WBCSD aan hoe bedrijven afhankelijk zijn of impact hebben op de door hen onderscheiden 11 ecosysteemdiensten. Opvallend is dat van de vijf typen bedrijven de financiële dienstverlening voor vrijwel alle ecosysteemdiensten relevant is. De financiële dienstverlening heeft een indirect effect op natuur, omdat ze voorwaarden kunnen stellen aan het kapitaal (en diensten) dat ze ter beschikking stellen aan bedrijven. Bedrijven die afhankelijk zijn van natuurlijk kapitaal lopen namelijk risico van schaarste en prijsstijging (ACCA et al., 2014). Grote langetermijnbeleggers hebben meer oog voor langetermijnrisico's die kleven aan de afhankelijkheid van natuurlijk kapitaal dan de bedrijven waarin ze (willen) investeren. We focussen in dit project met name op de directe effecten op natuur. De directe invloed van deze sector valt onder type IV (zie tabel 2.1), de indirecte invloed van de financiële dienstverlening is groter. 
Drie typen instrumenten

Deze typen bedrijven ( $I$ tot en met IV) geven niet alleen de interactie tussen bedrijven en natuur weer, maar ook de inzet van mogelijke beleidsinstrumenten. Bishop et al. (2009) onderscheiden drie typen instrumenten die bedrijven kunnen gebruiken om de waarde van biodiversiteit en ecosystemen mee te nemen in de besluitvorming, namelijk: compensatie-, certificering- en betalingsmechanismen. Afhankelijk van het type interactie dat een bedrijf met natuur heeft, wordt het instrument gebruikt om afspraken af te dwingen of juist op vrijwillige basis inzicht te geven in de prestaties. De 'hardheid' van het instrument verschilt dus tussen de typen bedrijven.

Waarde natuur

Om een goed inzicht te krijgen in het belang van natuur voor de welvaart is het nodig de waarde van natuur te kennen. Voor de bepaling van de waarde van natuur wordt het gebruik van natuur uitgesplitst (De Groot et al., 2010). Voor het deel dat we als intrinsieke waarde (culturele ecosysteemdienst) beschouwen wordt vaak biodiversiteit als maat gebruikt. Biodiversiteit speelt daarnaast ook een rol in de levering of ondersteuning van regulerende (productie) diensten, en heeft daarmee naast intrinsieke of culturele waarden ook economische waarden. Bijvoorbeeld bestuiving door een soortenrijke mix van (wilde) insecten is robuuster dan bestuiving alleen door honingbijen. Bestuiving door verschillende insecten leidt, onder voor honingbijen ongunstige omstandigheden, tot meer bevruchting en hogere opbrengsten (Vos et al., 2014).

Culturele diensten

In de ecosysteembenadering wordt biodiversiteit door De Knegt et al. (2014) geschaard onder de culturele diensten. Wij zullen dit overnemen met de kanttekening dat biodiversiteit ook bijdraagt aan andere ecosysteemdiensten. Ten slotte kunnen economische activiteiten, mits goed gestuurd, leiden tot een vergroting van diensten en goederen uit de natuur. Dit onderdeel is van groot belang voor een natuurinclusieve economie. In dat geval spreken we van win-winsituaties.

\subsection{Ecosysteemdiensten}

Ecosysteemdiensten zijn de goederen en diensten die ecosystemen verschaffen en die bijdragen aan welzijn en (economische) welvaart. Aanbod van en vraag naar ecosysteemdiensten is afhankelijk van de locatie (Troy en Wilson, 2006; Gaaff en Reinhard, 2012). Het aanbod van ecosysteemdiensten is door een aantal studies op verschillende schaalniveaus in kaart gebracht. Ook zijn raamwerken ontwikkeld om de monetaire waarde van ecosysteemdiensten te bepalen (Daily et al., 2009; De Groot et al., 2010). 
Tabel 2.2 Overzicht van ecosysteemdiensten a)

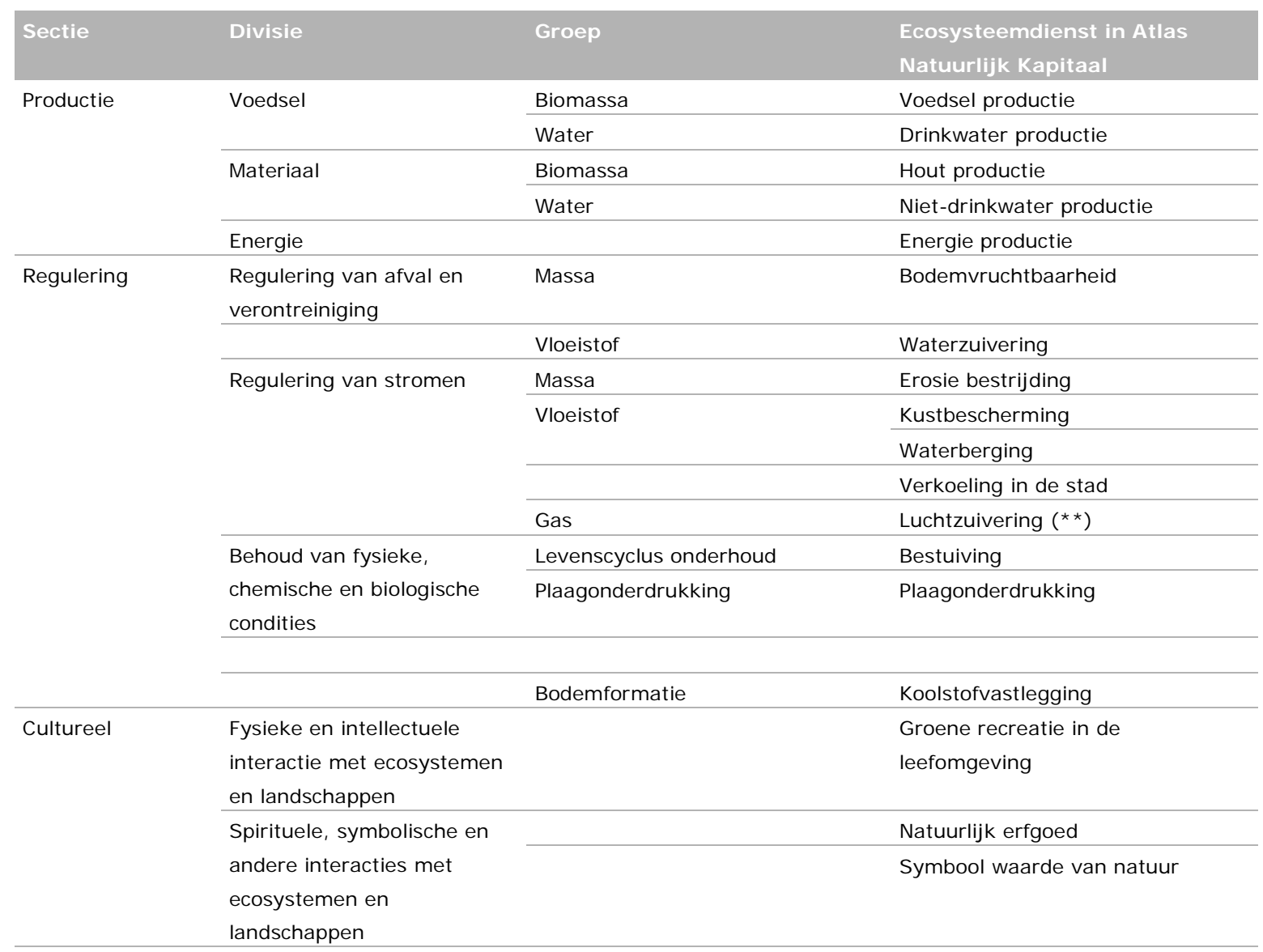

a) Voor luchtzuivering is geen indicator opgenomen in de Atlas Natuurlijk Kapitaal (Knegt et al., 2014)

Bron: Haines-Yong en Potschin (2013) en de Knegt et al. (2014), bewerking LEI.

(In) directe afhankelijkheid

Zoals eerder is aangegeven (tabel 2.1), zijn economische sectoren op verschillende wijzen afhankelijk van natuurlijk kapitaal en de ecosysteemdiensten die het natuurlijk kapitaal levert. Bestuiving,

plaagbestrijding, bodemerosie en bodemvruchtbaarheid zijn belangrijke ecosysteemdiensten voor de landbouwsector (tabel 2.2). Waterwinning, hout en vezels en minerale bronnen zijn van primair belang voor sectoren die deze diensten 'oogsten'. Ook de tertiaire sector (bedrijfstype IV in tabel 2.1) is afhankelijk van ecosysteemdiensten, maar deze afhankelijkheid is vaak indirect. Hierbij gaat het om diensten als groene recreatie, kustbescherming, en de realisatie van duurzaamheidsdoelen als hernieuwbare (biomassa) energie en koolstofvastlegging. Ook gezondheid (beïnvloed door luchtkwaliteit) is hier van belang. Tabel 2.3 geeft een globaal overzicht van de primaire afhankelijkheden van bedrijven aan ecosysteemdiensten. 
Tabel 2.3 Afhankelijkheid van bedrijven aan ecosysteemdiensten

\begin{tabular}{|c|c|c|}
\hline Dienst & Sector & Type afhankelijkheid \\
\hline Bestuiving & landbouw & bestuiving van gewassen voor vruchtvorming \\
\hline Plaagonderdrukking & landbouw & verlaging plaagdruk en gebruik van pesticiden \\
\hline Bodemerosie & landbouw & productiepotentieel op peil houden \\
\hline Bodemvruchtbaarheid & landbouw & productiepotentieel op peil houden \\
\hline Cultureel erfgoed & recreatie sector & inkomen door recreatief aantrekkelijke omgeving \\
\hline Groen & recreatie sector & inkomen door recreatief aantrekkelijke omgeving \\
\hline Hout, vezels & houtsector & primaire productie \\
\hline koolstofvastlegging & alle sectoren & doelstelling emissiereductie behalen \\
\hline Reinigend vermogen & alle sectoren & goede omgevingskwaliteit voor werknemers \\
\hline Verkoeling in de stad & alle sectoren & goede omgevingskwaliteit voor werknemers \\
\hline Schone lucht & Alle sectoren & goede omgevingskwaliteit/ gezondheid voor werknemers \\
\hline
\end{tabular}

\subsection{Meetbaar maken ecosysteemdiensten en natuurlijk kapitaal}

\subsubsection{Ecosysteemdiensten}

Vanaf 2015 lopen er verschillende initiatieven om de omvang van ecosysteemdiensten in kaart te brengen. In deze paragraaf beschrijven we de werkzaamheden van het RIVM (Atlas Natuurlijk Kapitaal) en het PBL (Natuurlijk Kapitaal Nederland). De Atlas Natuurlijk Kapitaal (ANK, 2016), die door het RIVM is ontwikkeld, brengt het natuurlijk kapitaal van Nederland in kaart aan de hand van indicatoren (graadmeters), met als product een Digitale Atlas. Hierbij zijn 26 thema's benoemd die gekoppeld zijn aan onderdelen van ecosysteemdiensten (zie tabel A1, bijlage 1). De indicatoren zijn weer gekoppeld aan ecosysteemdiensten en zijn ook weergegeven in tabel A2 (bijlage 2).Voor een groot aantal thema's zijn meer graadmeters opgenomen, die elk een ander aspect van een ecosysteemdienst meten. Niet alle thema's kunnen direct aan ecosysteemdiensten worden gekoppeld, maar hebben wel betrekking op de kwaliteit van ecosysteemdiensten. Zo is binnen het thema bodem het onderwerp bodemverontreiniging in een aantal graadmeters uitgewerkt. Deze informatie is relevant voor de ecosysteemdienst bodemvruchtbaarheid en zuiverend vermogen van de bodem. De graadmeter bodemverontreiniging zelf is dus geen indicator voor een ecosysteemdienst, maar wel voor de toestand.

Natuurlijk Kapitaal Nederland

Daarnaast heeft De Knegt et al. (2014) voor het project Natuurlijk Kapitaal Nederland (PBL, 2016) 18 ecosysteemdiensten uitgewerkt (zie paragraaf 2.2). Hierbij was de onderzoeksvraag om onder andere de omvang van vraag en aanbod van een dienst in Nederland en het buitenland vast te stellen en de herkomst van de dienst. Daarbij is onderzocht welke (bestaande) graadmeters hiervoor gebruikt kunnen worden. In die studie zijn dus geen nieuwe graadmeters voor ecosysteemdiensten ontwikkeld, maar is gezocht naar bestaande graadmeters en op welke wijze deze informatie geven over de toestand en de ontwikkeling met betrekking tot ecosysteemdiensten. Tabel A2 (bijlage 2) geeft het overzicht van de 18 onderzochte ecosysteemdiensten.

In het raamwerk Natuurlijk Kapitaal Nederland van het $\mathrm{PBL}^{1}$ wordt de TEEB-benadering toegepast. Deze benadering is beschreven in onder andere TEEB for local policy makers (TEEB, 2010) en omvat de volgende stappen: herkennen, waarderen en verzilveren. Binnen het project lopen verschillende gebiedsstudies om de TEEB-benadering te illustreren.

1 http://themasites.pbl.nl/natuurlijk-kapitaal-nederland/ 


\section{Graadmeters}

Beide projecten (RIVM en PBL) inventariseren ecosysteemdiensten in het frame van natuurlijk kapitaal. Hierbij wordt met name de aanbodzijde van ecosysteemdiensten in kaart gebracht. Hoewel De Knegt et al. (2014) ook de vraagzijde van ecosysteemdiensten adresseert, blijkt dit bijzonder lastig te kwantificeren. Uit de tabellen uit de bijlagen A1 (bijlage 1) en A2 (bijlage 2) van beide projecten komt daarnaast naar voren dat er op dit moment weinig graadmeters beschikbaar zijn om capaciteit en/of kwaliteit van de te leveren ecosysteemdiensten en de trend erin direct te meten. De graadmeters die naar voren worden gebracht kunnen wel als 'proxies' gebruikt worden, maar laten vooral zien dat voor vrijwel elke ecosysteemdienst meer graadmeters nodig zijn om de toestand en trend in kaart te brengen. Daarbij is met name de (maatschappelijke) vraag naar diensten nog niet goed in kaart gebracht en zijn hiervoor nog geen goede graadmeters ontwikkeld.

\subsubsection{Natuurlijk kapitaal}

In de literatuur zijn verschillende methoden ontwikkeld om het natuurlijk kapitaal te meten. De term Natural Capital Index en het daarvan afgeleide natuurlijk kapitaal wordt vaak gebruikt om de voorraadgrootheid natuur of biodiversiteit te omschrijven. Dit kan verwarring scheppen met een term als natural capital accounting. In dit laatste worden de economische aspecten (financiële stromen) van natuurlijk kapitaal in ogenschouw genomen, waarbij alle voorraadgrootheden worden gebruikt, inclusief aardolie, gas, mineralen enzovoort. Voor natural capital accounting zijn verschillende systematieken ontwikkeld, zoals System of Environmental-Economic Accounting (SEEA), Wealth Accounting and Ecosystem Partnership Services (WAVES), Ecological Footprint accounts en, naast Inclusive Wealth Index, nog vele andere graadmeters. Deze methoden meten vaak verschillende onderdelen van voorraadgrootheden, maar ook gebruik zoals Ecological Footprint accounts.

\section{CBS}

Op nationaal niveau is het CBS verantwoordelijk voor het in kaart brengen van milieurekeningen. De milieurekeningen van het CBS zijn opgebouwd rondom de 'National Accounting Matrix including Environmental Accounts' (NAMEA), waarin de samenhang tussen een aantal belangrijke economische indicatoren en het milieu wordt getoond. Biodiversiteit wordt echter niet gemeten in de milieurekeningen. Wel worden de drukfactoren op biodiversiteit in kaart gebracht, zoals emissies naar water en lucht. Daarnaast worden milieukosten en -investeringen in kaart gebracht maar het kan niet herleid worden of deze ten goede komen aan biodiversiteit.

\section{Diversiteit}

Het deel van natuurlijk kapitaal dat verwijst naar biodiversiteitsaspecten, wordt vaak gemeten aan de hand van soortenrijkdom, weergegeven door het aantal of de diversiteit aan soorten. Vaak is er speciale aandacht voor de status van soorten en worden alleen specifieke soorten geteld, bijvoorbeeld zeldzame soorten of aandachtsoorten van natuurbeleid op nationaal of Europees niveau (bijvoorbeeld rode lijst soorten). Aan de andere kant zijn er ook soorten die een negatieve indicator zijn voor natuurkwaliteit, onder andere invasieve soorten, plaagsoorten en ziekten.

Type en omvang leefgebied

Natuurkwaliteit kan ook gemeten worden aan de hand van type en omvang van het leefgebied, bijvoorbeeld specifiek door de staat van instandhouding van natuurtypen die in Natura 2000-gebieden liggen. Van een leefgebied wordt areaal en beheertype weergegeven, vaak vergezeld van een kartering van het gebied. Habitattypen kunnen ook een negatieve indicator zijn, bijvoorbeeld habitattypen die ontstaan door vermesting, verdroging en/of door verruiging.

Natural Capital Index

Binnen het PBL is in het verleden de Natural Capital Index ( $\mathrm{NCl}$ ) (ten Brink et al., 2000) ontwikkeld om de biodiversiteit en veranderingen hierin op mondiaal niveau te kunnen berekenen. Deze index is opgenomen in het mondiale model GLOBIO (Global Biodiversity) en kan worden gedefinieerd als: $\mathrm{NCl}=$ ecosystem quantity (\%) * ecosystem quality (\%). Hier is later de Mean Species Abundance MSA- (Alkemade et al., 2009) uit ontstaan. Deze maat wordt veel gebruikt in internationale verkenningen en is opgenomen in de CBD methodiek om de doelstellingen ten aanzien van biodiversiteit in kaart te brengen (zie ook PBL, 2012 (Roads to Rio report). Voor Nederland is de MSA- 
methodiek aangepast omdat nauwkeurige data beschikbaar zijn: de natuurpuntenmethodiek. De methodiek rond natuurpunten is uitgebreid beschreven door het PBL $(2009,2014)$. De methode kan gebruikt worden in MKBA-studies, waarbij voor niet-monetaire zaken zoals biodiversiteit een alternatieve waardering is opgenomen. De methode om natuurpunten te berekenen is gebaseerd op dezelfde systematiek als de Natural Capital Index waarbij de kwaliteit en kwantiteit van ecosystemen wordt gemeten voor verschillende alternatieven.

Referentie en context

Wanneer we dus spreken over natuurlijk kapitaal dan is het van belang de referentie en de context weer te geven. In de economische context wordt bij natuurlijk kapitaal gerefereerd naar alle voorraadgrootheden, inclusief voorraden fossiele brandstoffen, mineralen, enzovoort, terwijl in de ecologische context naar natuur wordt verwezen waarbij vooral de kwaliteit van natuur een aandachtspunt is. Elementen van het abiotisch natuurlijk kapitaal kunnen behalve de soortenrijkdom of de omvang van leefgebied ook de kwaliteit van leefgebied (de fysieke condities van het leefgebied) beïnvloeden. Zo kan het beperken van watergebruik verdroging van leefgebied tegengaan en het terugdringen van pesticidengebruik watervervuiling van een leefgebied tegengaan.

De in deze paragraaf beschreven methoden om natuurlijk kapitaal te meten, worden niet verder uitgewerkt in deze rapportage. We concentreren ons op ecosysteemdiensten.

\subsection{Meetbaar maken van relatie bedrijven met natuur}

De studies waarin het gebruik van ecosysteemdiensten wordt bepaald, kunnen ook op bedrijfsniveau worden uitgevoerd. De relatie die bedrijven met ecosysteemdiensten hebben, kan op enkele manieren worden vastgelegd:

- footprint ontleend aan $\mathrm{NCl}$ (zie ook paragraaf 2.3.2. meetbaar maken van natuurlijk kapitaal)

- jaarrapportage

- keurmerk.

\subsubsection{Footprint}

De NCl-methode (zie paragraaf 2.3.2) is in gebruik bij platform BEE (Biodiversiteit, Ecosystemen en Economie). Deze beschrijft en meet de impact van bedrijven op biodiversiteit wereldwijd door van bedrijven de uitstoot van $\mathrm{CO}_{2}$, het gebruik van water en het landgebruik (de impact van het bedrijf op milieucondities) om te zetten in een biodiversiteitsindicator (met eenheid species.year). Deze eenheid is een maat voor het mondiale risico op verlies van soorten (Bergsma et al., 2014). Voordeel van deze methode van registreren, is dat hij aanhaakt op het gebruik van grondstoffen door bedrijven, wat bedrijven al rapporteren. De output is een bijdrage aan biodiversiteit (wereldwijd), een indicator die voor consumenten/burgers aantrekkelijk is.

\subsubsection{Jaarrapportage en milieurekeningen}

Het WBCSD-raamwerk gaat in op de ecosysteemdiensten waarvan bedrijven afhankelijk zijn en die bedrijven beïnvloeden (zie ook TEEB Nederlandse bedrijfsleven, KPMG, 2012). De analyse wordt toegepast door bedrijven die meer natuurinclusief willen worden, om bijvoorbeeld bedrijfsrisico's te verkleinen. De analyse (en de eventuele meting) wordt niet (standaard) openbaar gemaakt. J aarrapportages kunnen informatie leveren over een natuurinclusieve economie. Dit kan of via de impact op milieucondities (zie hierboven bij platform BEE) of via de directe impact op natuur. GRI 4 is de standaard voor duurzaamheidsrapportages, ontwikkeld door de Global Reporting Initiative en een vervolg op de al eerdere uitgewerkte standaard GRI3 (GRI, 2016). In GRI4 is biodiversiteit als een nieuw separaat thema opgenomen. Rapportages onder GRI zijn zogenaamde 'disclosures' en geven een gestandaardiseerd overzicht van criteria die opgenomen worden in de milieurekeningen van bedrijven. Op deze wijze kunnen er benchmarks gemaakt worden van sectoren, landenregio's en tussen bedrijven. Het rapporteren zegt overigens niets over de impact zelf. Met name de indicatoren gerelateerd aan biodiversiteit geven wel informatie over de impacts van een bedrijf op biodiversiteit, maar geen informatie of en hoe die impact verkleind kan worden. 
Drie criteria

In rapportages volgens de GRI4-richtlijnen zijn er 3 typen criteria te onderscheiden: criteria die informatie geven over biodiversiteit (zoals het maken van een beheersplan), criteria die de impact aangeven op soorten of leefgebied (zoals aanleg infrastructuur), en criteria die gericht zijn op bescherming of herstel van soorten of leefgebied (zoals het aanpassen van maaibeheer of het plaatsen van nestkasten). Er zijn nog een aantal overige criteria, zoals periodiek monitoren, het inzetten deskundigen, en het karteren van het (bedrijven)terrein. GRI4 gaat niet in of natuurdoelen worden bereikt. Naast biodiversiteit rapporteert GRI 4 over de categorieën energie, water, emissies en productdienst.

Tabel 2.4 Indicatoren biodiversiteit opgenomen in de GRI4-rapportage.

\begin{tabular}{|c|c|}
\hline Categorie & I ndicatoren \\
\hline informatie bedrijf/terrein & $\begin{array}{l}\text { - } \text { keuze locatie } \\
\text { - beschrijving omvang en type bedrijvigheid } \\
\text { - beschrijven huidige situatie qua habitat en soorten } \\
\text { - beschrijven huidig beheer } \\
\text { - beschermingsstatus soorten/habitat }\end{array}$ \\
\hline $\begin{array}{l}\text { habitats/soorten hersteld of } \\
\text { beschermd }\end{array}$ & $\begin{array}{l}\text { - beschrijven situatie einde rapportageperiode } \\
\text { - vaststellen gewenste toekomstige ontwikkeling terrein } \\
\text { - beschrijven herstelactiviteiten/ toekomstig beheer } \\
\text { - uitvoeren herstelactiviteiten } \\
\text { - herstelactiviteiten: beschrijven verbetering einde rapportageperiode. }\end{array}$ \\
\hline
\end{tabular}

Bron: in aangepaste vorm overgenomen van Global Reporting Initiative: Reporting Principles and Standard Disclosures.

\subsubsection{Keurmerken}

Keurmerken stellen eisen aan bedrijven. Als deze eisen direct of indirect (via milieucondities) gunstig zijn voor de natuur, kan aan de hand van het aantal deelnemende bedrijven (of areaal) de bijdrage aan natuur worden bepaald. Keurmerken kunnen ook voor projecten gelden (bijvoorbeeld BREEAM). De keurmerkhouder is de partij die het aantal deelnemers en areaal of het aantal producten onder het keurmerk meet, zoals Stichting Milieu Keurmerk (SMK).

\subsection{Ecologische waarde/biodiversiteit}

\section{Schaalniveaus}

Bij het bepalen van de invloed van een bedrijf op zijn omgeving is de ruimtelijke schaal waarop effecten geanalyseerd worden een belangrijke factor. Een individueel bedrijf beïnvloedt natuur vaak op een laag schaalniveau (terrein van het bedrijf en de directe omgeving), terwij I natuurlijke processen op een reeks van ruimtelijke schalen functioneren, variërend van lokaal, regionaal tot zelfs internationaal. Wat op het ene schaalniveau gebeurt, heeft ook invloed op de natuur en natuurlijke processen op andere schaalniveaus. Klimaatverandering is een proces op internationale schaal waarbij de geschikte klimaatzones van soorten opschuiven. Dit zijn grootschalige processen in ruimte en tijd die invloed hebben op het voorkomen van soorten (het internationale schaalniveau in figuur 2.4). Maar ook op lokaal niveau spelen zich natuurlijke processen af, zoals natuurlijke plaagregulatie op een akker. Natuurlijke plaagregulatie en bestuiving functioneren dankzij de insecten die leven in de fijnmazige natuurlijke elementen in het landschap, zoals houtwallen, bloemrijke akkerranden en natuurvriendelijke oevers (het lokale schaalniveau in figuur 2.4). De agrariër die gebruik wil maken 
van deze ecosysteemdiensten op zijn bedrijf is afhankelijk van zijn omgeving. Hoe meer boeren in de regio samenwerken aan een sterk netwerk van houtwallen of bloemrijke akkerranden, hoe effectiever de dienst zal worden geleverd. Daarnaast is de biodiversiteit in dit fijnmazige netwerk voor haar voortbestaan op de lange termijn afhankelijk van de natuurgebieden in de regio, zodat soorten na een plaatselijke verstoring weer terug kunnen komen (het regionale schaalniveau in figuur 2.4). Er bestaat dus een wisselwerking tussen de verschillende schaalniveaus, die de effectiviteit van maatregelen op bedrijfsniveau beïnvloeden. Het is belangrijk bij het opstellen van indicatoren voor biodiversiteit rekening met de schaal te houden waarop de biodiversiteit en ecosysteemdiensten functioneren.

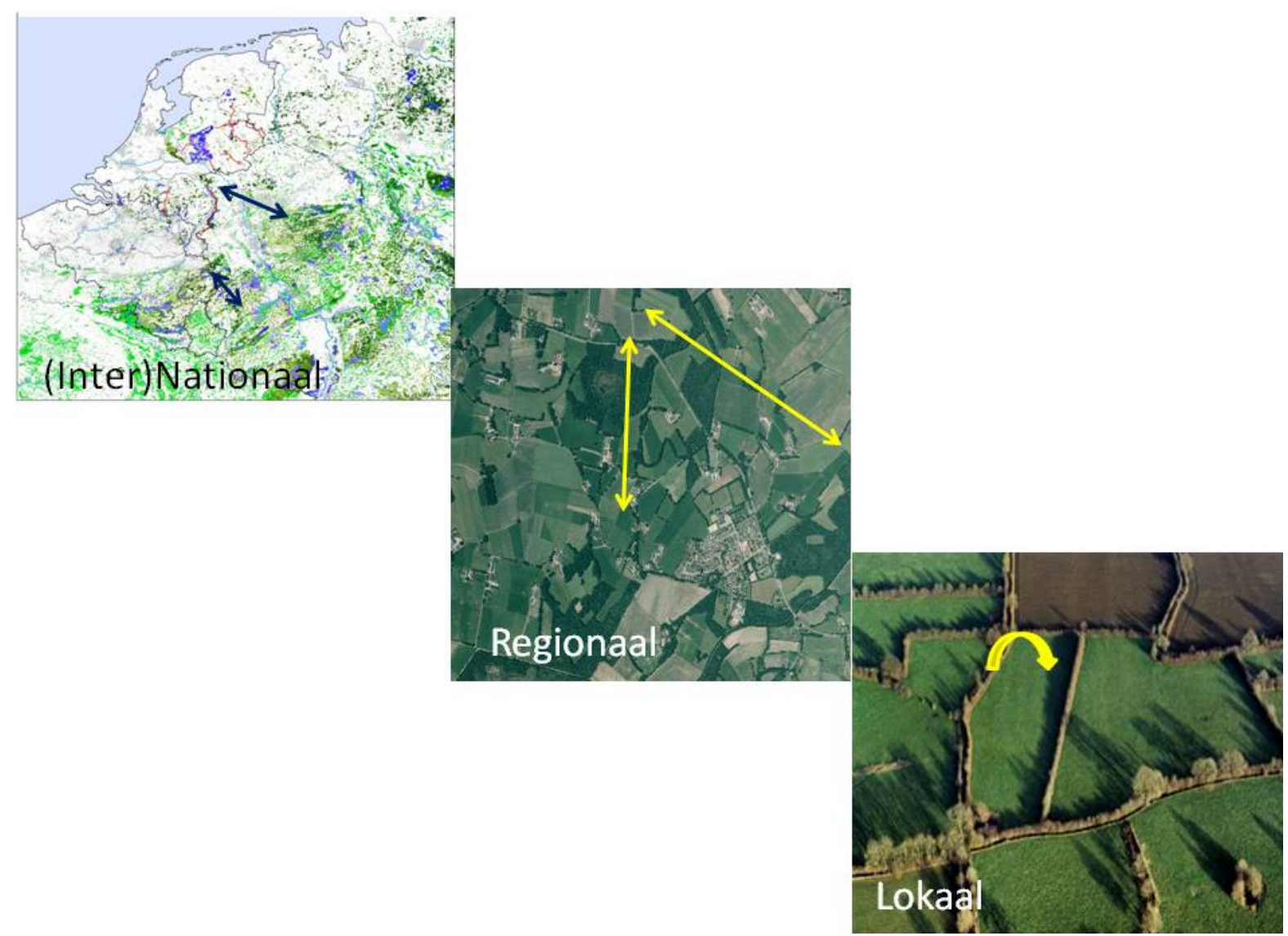

Figuur 2.4 Het functioneren van biodiversiteit en ecosysteemdiensten is afhankelijk van de wisselwerking tussen schaalniveaus

\subsection{Synthese}

In hoofdstuk 2 zijn de relevante natuurbegrippen beschreven (natuurlijk kapitaal, ecosysteemdiensten en biodiversiteit) en ook hoe deze begrippen in de praktijk kwantitatief worden bepaald, waarbij iedere methode zijn eigen focus kent. Er wordt een aantal methoden (onder andere Maes et al., 2013; OpenNess 2014; Spurgeon, 2014; NCC, 2015) toegepast om (een deel van) de relatie tussen natuur en economie te kwantificeren. Deze methoden baseren zich op raamwerken waarin natuurlijk kapitaal ecosysteemdiensten levert die worden ingezet in het sociaaleconomische systeem, dat weer een impact heeft op het natuurlijk kapitaal. Geen van deze raamwerken geeft een complete beschrijving van de economie (overeenkomstig de beschrijving van natuurlijk kapitaal). Om het effect van beleidsinstrumenten gericht op het stimuleren van natuurinclusieve economie te kunnen duiden is inzicht nodig in het effect op de economie. Anders kan de substitutie tussen het gebruik van de natuur en technische oplossingen niet worden weergegeven. In hoofdstuk 3 zullen we een raamwerk presenteren waar de economie expliciet is meegenomen. 
Bestaande metingen en rapportages

Er wordt al gemeten en gerapporteerd over de relatie tussen natuur en economie. Het meten van deze relatie wordt (onder andere) op bedrijfsniveau (NCC, 2015) en op nationaal niveau (Maes et al., 2013; de Knegt et al., 2014) gedaan. Zo rapporteren met name grotere bedrijven over hun duurzaamheidsprestaties op het niveau van de gehele onderneming (en niet per regio). De duurzaamheidsprestatie van een bedrijf op $\mathrm{CO}_{2}$-emissie en watergebruik is gemakkelijker te meten dan de directe prestatie op gebied van natuur. $\mathrm{CO}_{2}$-emissie en watergebruik op verschillende locaties is optelbaar; de bijdrage aan natuur is locatiespecifiek. Op verschillende locaties wordt de aanwezigheid van verschillende plant- en diersoorten (vrijwillig) geteld door ecologen. De metingen van bedrijven en van ecologen zijn niet eenvoudig aan elkaar te koppelen, waardoor het niet mogelijk is om na te gaan hoe groot het effect van natuurinclusieve economie op natuur is. Voor het opzetten van een meet- en rapportage systeem zijn alle betrokken stakeholders noodzakelijk. Er is (voor zover we hebben kunnen achterhalen) nog geen aggregatie gemaakt van de meetresultaten op het gebied van natuurlijk kapitaal en ecosysteemdiensten op bedrijfsniveau naar hogere schaalniveaus. 


\section{Generiek raamwerk}

In figuur 3.1 presenteren we een generiek raamwerk om natuurinclusieve economie voor bedrijven schematisch weer te kunnen geven. In deze figuur staat het bedrijf centraal, omdat voor natuurinclusieve economie op bedrijfsniveau de keuzes worden gemaakt voor het gebruik van ecosysteemdiensten. Het generieke raamwerk bestaat uit een marktgericht economisch gedeelte (3. halffabricaten, 4. Bedrijf en 5. Marktproduct), een ecologisch gedeelte (1. Natuurlijk kapitaal, 2. Ecosysteemdiensten, 6 Nevenproducten) en de maatschappij, die met elkaar samenhangen. Door de combinatie van deze drie gedeelten is dit raamwerk een uitbreiding op reeds bestaande raamwerken. Deze bestaande raamwerken (Maes et al., 2013; OpenNess, 2014; Spurgeon, 2014 en NCC, 2015) passen binnen ons raamwerk.

Incompleet

Geen van deze bestaande raamwerken geeft een complete beschrijving van de economie (overeenkomstig de beschrijving van natuur en milieu). Om het effect van beleidsinstrumenten van natuurinclusieve economie te kunnen duiden is ook inzicht nodig in de economie. Anders kan bijvoorbeeld de substitutie tussen het gebruik van natuurlijk kapitaal (pijl A: Gebruik) en technische oplossingen (pijl C: Gebruik) niet worden weergegeven. Het gaat dan bijvoorbeeld om:

i. waterzuivering in de duinen versus zuivering met filters en chemicaliën en

ii. efficiënter gebruik van water in de landbouw door gebruik van druppelirrigatie

iii. circulaire economie, waarbij marktproducten via hergebruik weer input kunnen zijn van het productieproces en (via pijl C: Gebruik) het gebruik van natuurlijk kapitaal (pijl A: Gebruik) verminderen.

Interactiepijlen

Pijlen geven de interactie aan tussen de onderdelen van het raamwerk. Dit zijn ook de aangrijpingspunten voor beleid van overheid en strategieën van bedrijfsleven. Daarnaast is het schaalniveau van belang. De ecosysteemdiensten en milieucondities (onder andere emissies) zijn gekoppeld aan de locatie van het bedrijf. Deze kunnen natuurlijk een effect hebben dat veel verder reikt dan het lokale schaalniveau. Met de pijl ' $\mathrm{H}$ ' is de circulaire economie weergegeven, waarbij marktproducten worden hergebruikt als input in het productieproces.

In de beschrijving van het raamwerk volgen we de nummering van figuur 3.1. 


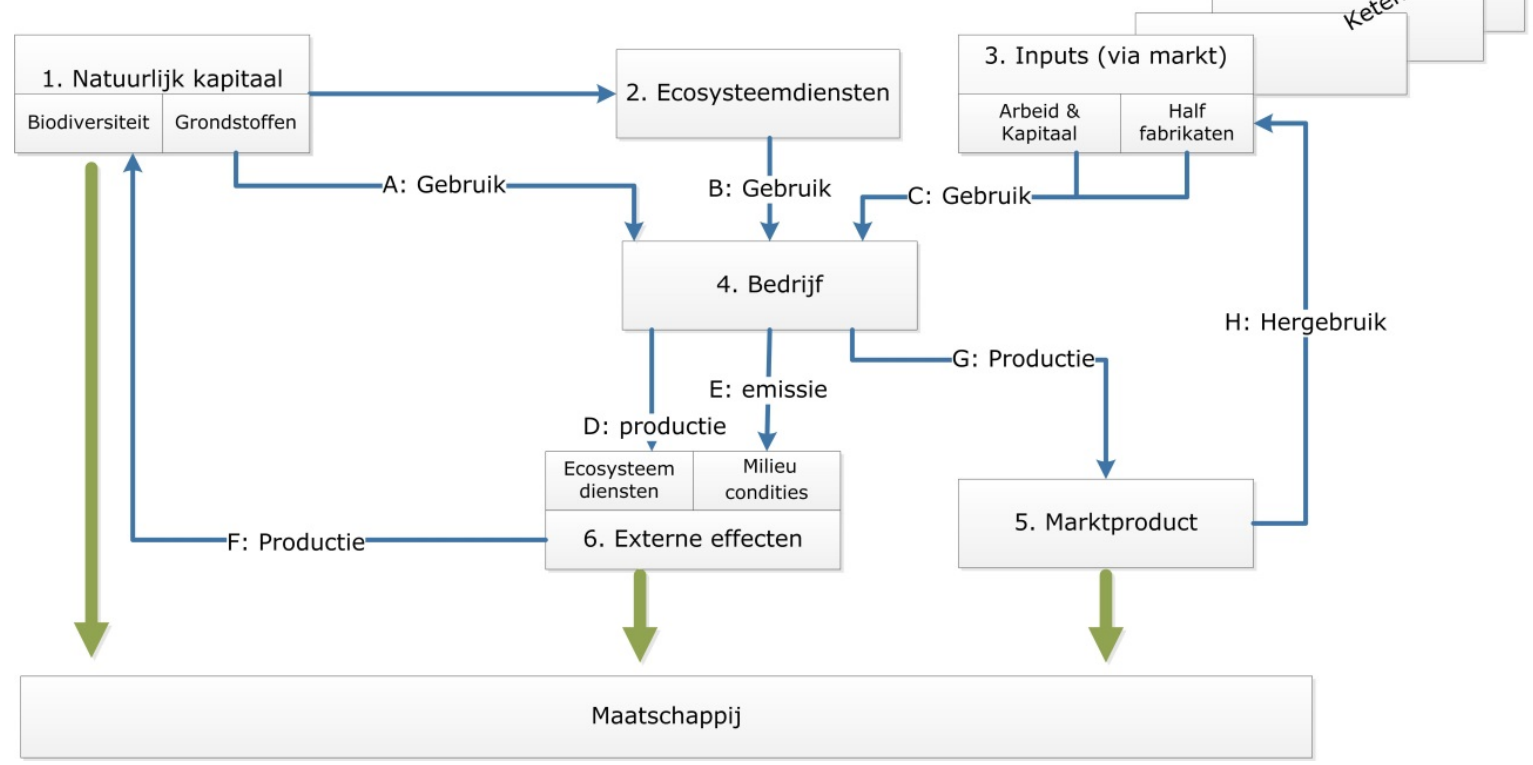

Figuur 3.1 Raamwerk Natuurinclusieve economie

De onderdelen uit het generieke raamwerk zijn:

1. Natuurlijk kapitaal is een voorraadgrootheid en bestaat uit biodiversiteit (rode lijst soorten en ander flora en fauna) en abiotische grondstoffen (bijvoorbeeld grind, water, nitraat, fosfaat). Grondstoffen zijn in veel gevallen via concessies aan (mijnbouw) bedrijven verkocht. Deze verkopen grondstoffen op de markt, waarmee het een marktgoed is geworden. Natuurlijk kapitaal is relevant op zowel lokaal schaalniveau als op hogere niveaus.

2. Natuurlijk kapitaal levert ecosysteemdiensten (een stroomgrootheid). Deze diensten worden door bedrijven aangewend (lokaal schaalniveau). In veel gevallen is daarvoor geen markt.

3. Daarnaast gebruikt een bedrijf inputs via de markt. Dit zijn factor inputs (arbeid en kapitaal) en non-factor inputs (halffabricaten), die via andere bedrijven worden ingekocht. Via de halffabricaten komen de ecosysteemdiensten en grondstoffen die eerder in de keten op een andere locatie (bijvoorbeeld uit het buitenland) zijn gebruikt in het raamwerk. Voor de productie van de halffabricaten is ook een raamwerk op te stellen, zodat er in een productketen verschillende raamwerken kunnen worden opgesteld. Dit is met 'keten' en 'buitenland' rechtsboven in het raamwerk weergegeven.

4. Het bedrijf zet ecosysteemdiensten, grondstoffen en markt-inputs (arbeid, kapitaal en halffabricaten) om in marktproducten en nevenproducten. Aangezien grondstoffen en markt-inputs worden ingekocht is de hoeveelheid die een bedrijf ervan gebruikt, bekend. Van het gebruik van ecosysteemdiensten is veel minder bekend op bedrijfsniveau.

5. Marktproducten dragen bij aan het bedrijfsresultaat en worden verhandeld aan consumenten of (als halffabricaat) aan andere bedrijven. Van deze marktproducten is redelijk veel bekend op bedrijfsniveau. Als marktproducten aantoonbaar natuurinclusief worden geproduceerd, bijvoorbeeld via een keurmerk geborgd, kan dit een meerwaarde hebben voor de consument.

6. Nevenproducten zijn producten die niet via de markt worden afgezet. Het gaat dan om externe effecten zoals emissies naar het milieu (lokaal niveau; waar al of niet regels voor gelden of beleid op wordt gevoerd) en bijdragen (positief dan wel negatief) aan ecosysteemdiensten. Voor enkele nevenproducten geldt een registratieverplichting (bijvoorbeeld voor dierlijke mest). Van de meeste nevenproducten is echter weinig bekend op bedrijfsniveau.

De welvaart van de maatschappij bestaat zowel uit het natuurlijk kapitaal gedeelte als uit het economische gedeelte. Dit is in figuur 3.1 aangeduid door de pijlen van marktproduct (hier is het Bruto Binnenlands Product (BBP) op gebaseerd), externe effecten (niet in BBP), en natuurlijk kapitaal (niet in BBP) naar maatschappij. Om een betere indicator voor de nationale welvaart te ontwikkelen, wordt gekeken hoe natuurlijk kapitaal en externe effecten ook meegenomen kunnen worden. 


\section{Beleidsopties}

Beleid kan op verschillende plaatsen ingrijpen in het generieke raamwerk. Opties voor beleid (van overheid of bedrijven) en specifiek voor EZ-instrumenten zijn weergegeven met de blauwe pijlen (bijvoorbeeld: A: Gebruik) van figuur 3.1. Deze pijlen zijn met aangrijpingspunten voor beleid weergegeven in figuur 3.2. We beschrijven in tabel 3.1 deze pijlen, noemen een voorbeeld van mogelijk (of bestaand) beleid, en geven aan hoe de omvang (van deze pijl) wordt gemeten/gerapporteerd. Beleid voor natuurinclusieve economie gaat een stap verder dan de reeds bestaande wet- en regelgeving.

Afhankelijkheid en impact

In de methoden waarin de interactie tussen bedrijven en natuurlijk kapitaal (en ecosysteemdiensten) wordt beschreven (onder andere WBCSD, 2011; Spurgeon, 2014 en figuur 2.2), wordt weergegeven dat bedrijven afhankelijk zijn van ecosysteemdiensten en dat zij impact hebben op ecosysteemdiensten. De afhankelijkheid is in figuur 3.1 pijl B, de impact is pij। D en E.

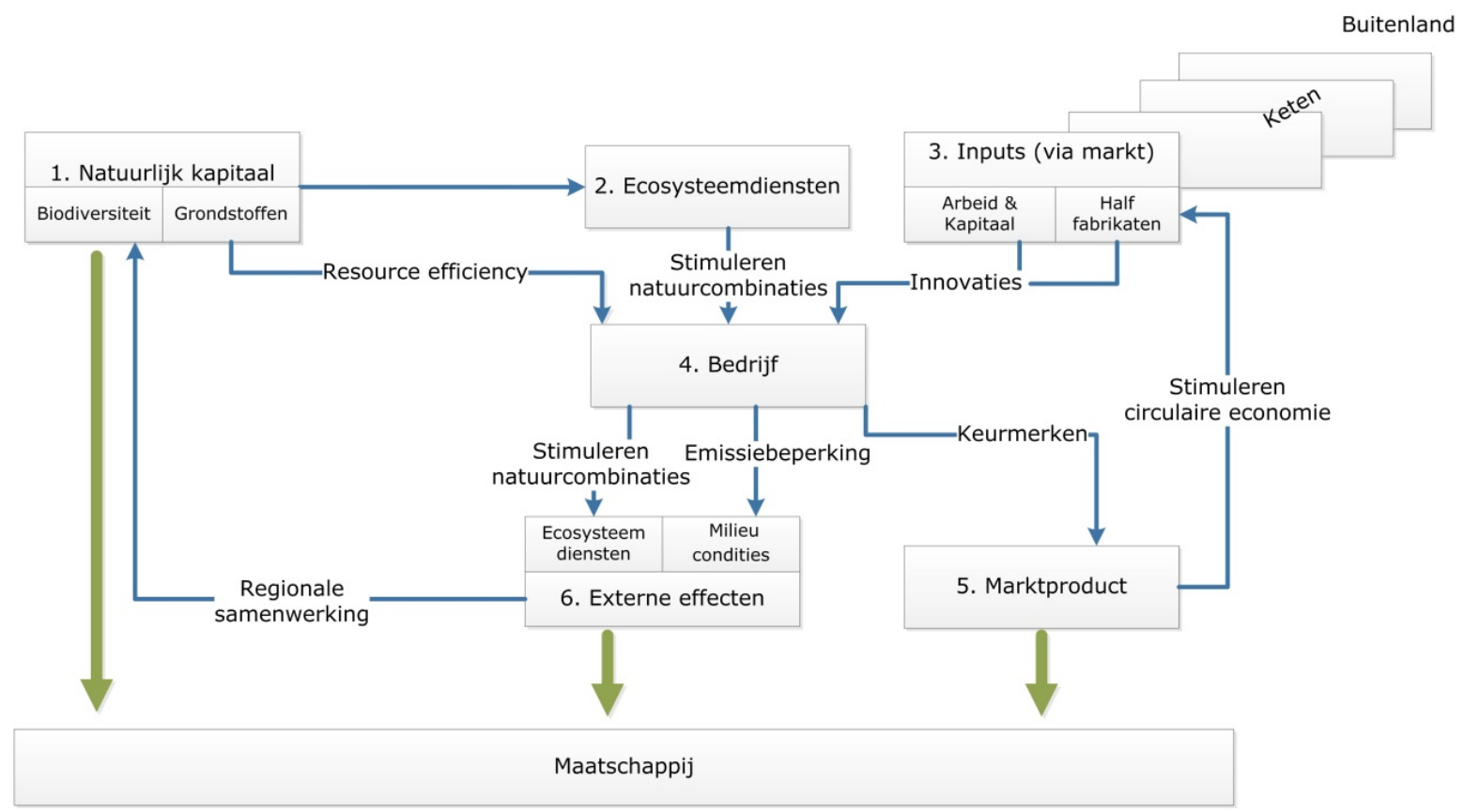

Figuur 3.2 Raamwerk Natuurinclusieve economie met aanknopingspunten voor beleid 
Tabel 3.1 Beleidsopties om natuurinclusieve economie te stimuleren (via aanpassingen in het productieproces van het bedrijf), op basis van het generieke raamwerk van figuur 3.1 en figuur 3.2.

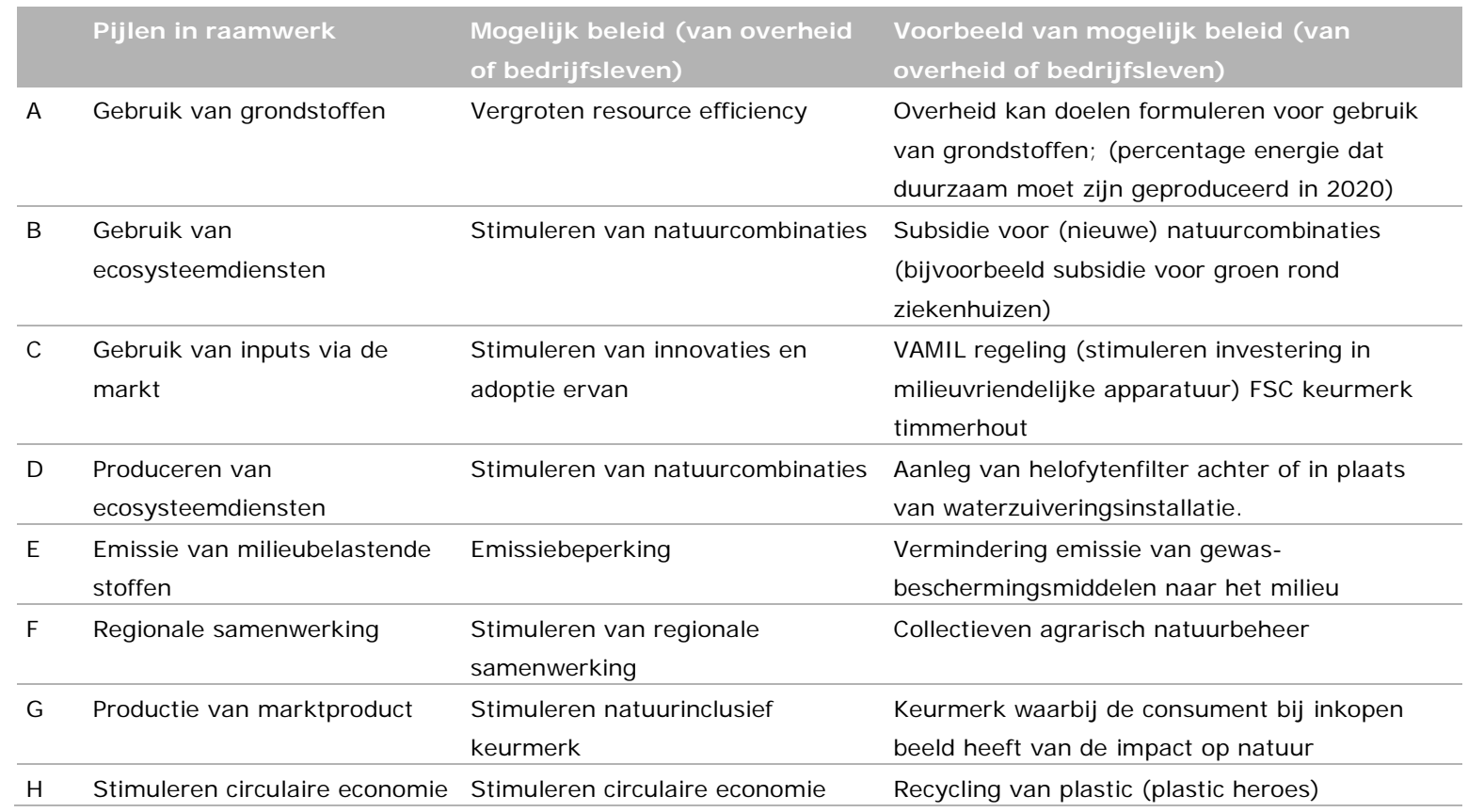

Zoals in hoofdstuk 2 is geconstateerd, wordt er al veel gemeten op deelrelaties van de natuurinclusieve economie. Om een (niet-uitputtend) beeld te schetsen van rapportages over deze deelrelaties, zijn deze opgenomen in ons raamwerk (zie figuur 3.3). Overheid en bedrijven hebben beide relevante gegevens op een verschillend schaalniveau. Overheden hebben meer gegevens over de voorraad (bijvoorbeeld natuurlijk kapitaal) en gegevens op hoger schaalniveau (provincie of rijk), bedrijven hebben meer informatie over de stromen en gegevens op een lager schaalniveau. In verschillende ketens wordt er gewerkt aan verbetering van de informatievoorziening tussen ketenpartijen (bijvoorbeeld de glastuinbouw; zie Verdouw et al., 2014). CBS stelt bijvoorbeeld de emissieregistratie op, op basis van informatie van bedrijven. De mogelijkheden voor verbetering van informatie-uitwisseling voor natuurinclusieve economie zouden geanalyseerd kunnen worden (bijvoorbeeld in het kader van Atlas Natuurlijk Kapitaal).

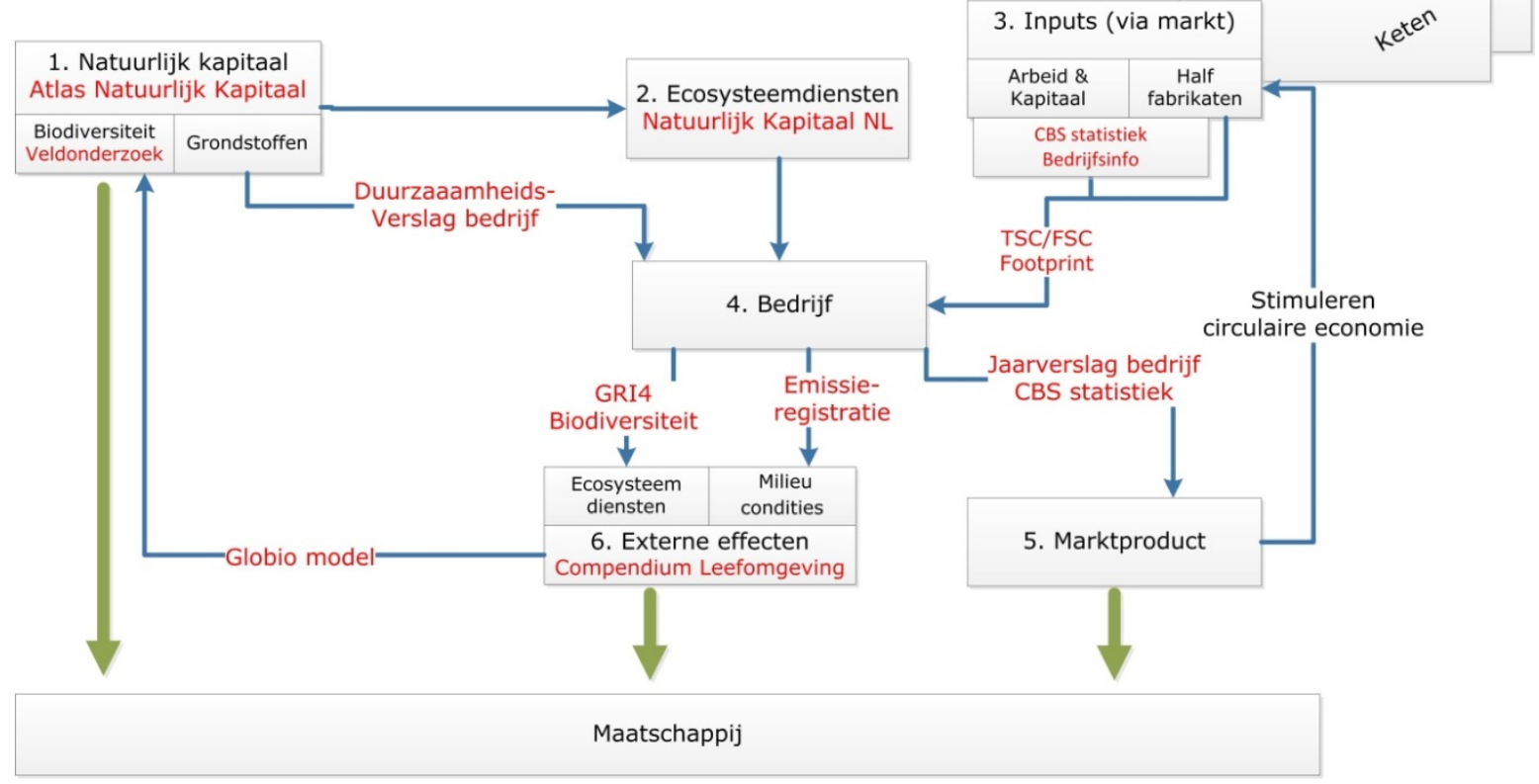

Figuur 3.3 Raamwerk Natuurinclusieve economie met bestaande rapportages (weergegeven in rood) over deelrelaties binnen de natuurinclusieve economie 
Kwantificeren met en zonder beleid

Om het effect van beleid te kunnen bepalen zou idealiter het raamwerk met en zonder beleid (aanpassing in het productieproces) moeten worden gekwantificeerd. Voor het bepalen van effecten van beleid zijn evaluatiemethodieken ontwikkeld. Voor de evaluatie van het Europees plattelandsbeleid is door de EU het Common Monitoring and Evaluation Framework, CMEF (COM, 2006) opgesteld. We gebruiken CMEF als basis voor het meten van het effect van natuurinclusieve economie, zoals ook in Fontein et al. (2015) is gedaan. Bij toepassing van CMEF moeten de volgende indicatoren worden bepaald:

- waar het beleid ingrijpt in het productieproces (de pijlen A tot en met $\mathrm{H}$ in het generieke raamwerk),

- hoeveel bedrijven hun productieproces aanpassen op basis van het beleid (output indicator)

- wat het effect van het beleid op het productieproces is (outcome bedrijf)

- wat het effect van het beleid op de omgeving van het bedrijf is (outcome omgeving; hoger schaalniveau dan het bedrijf)

- in hoeverre het beleidsdoel wordt gerealiseerd (impact indicator).

De CMEF-methode sluit aan op methoden die zijn ontwikkeld om het effect van beslissingen over ecosysteemdiensten te analyseren (zie De Blaeij et al., 2011; Daily et al., 2009). In deze methoden wordt het effect van de beslissing om te investeren in de ecosysteemdienst, teruggekoppeld naar het doel van de investering, zodat er een veranderingscirkel ontstaat; zie figuur 3.4.

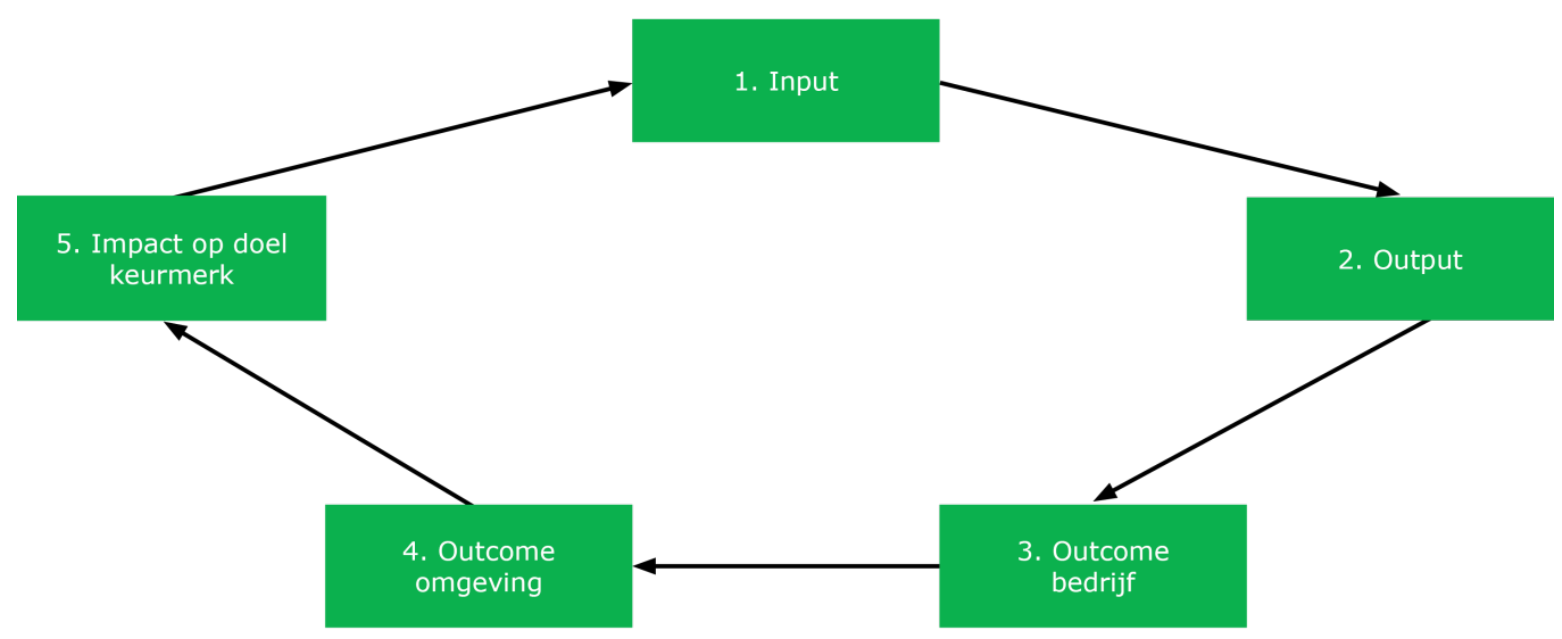

Figuur 3.4 CMEF-evaluatieraamwerk voor rendement natuurinclusieve economie op natuur, met als voorbeeld een keurmerk Gebaseerd op COM (2006) en de Blaeij et al. (2011).

Toepassing op 'groene' keurmerken

We passen (als illustratie) deze methodiek toe op verschillende 'groene' keurmerken: Blief (voorheen biodiversiteit+), Green Key en BREEAM. Deze keurmerken, die door de sector zijn opgericht, stellen eisen aan de bedrijven onder andere over het gebruik van de natuur, die verdergaan dan de wettelijke eisen. Bedrijven kiezen er zelf (vrijwillig) voor om zich aan te sluiten bij een groen keurmerk. Dit betekent dat zij er ook voordelen van zien. De onderdelen van de keurmerken die een positief effect hebben op natuur (en bovenwettelijk zijn), kunnen als natuurinclusieve economie worden beschouwd. De drie keurmerken die worden geanalyseerd zijn ook alle drie betrokken bij een green deal. Enkele keurmerken kennen ook een gradatie, waarbij een bedrijf door extra aanpassingen (optionele of bonuscriteria) een hoger niveau van het keurmerk kan halen (bijvoorbeeld, brons, zilver en goud). De keurmerkhouders registreren al een aantal van de bovenbeschreven indicatoren, onder andere hoeveel bedrijven zijn aangesloten en welke aanpassingen in de bedrijfsvoering ze hebben gedaan. 
Tabel 3.2 Overzicht van de keurmerken (voorbeelden van natuurinclusieve economie) die worden geanalyseerd

\begin{tabular}{|c|c|c|c|}
\hline Keurmerk & Sector & Bedrijfstype (tabel 2.1) & Keurmerk gaat over de volgende pijlen \\
\hline \multirow[t]{2}{*}{ Blief } & Akkerbouw & Type I & $A=$ gebruik grondstoffen \\
\hline & & & $\mathrm{D}=$ natuurcombinaties \\
\hline \multirow{2}{*}{ Green Key } & & & $\mathrm{C}=$ gebruik inputs \\
\hline & & & $\mathrm{D}=$ natuurcombinaties \\
\hline
\end{tabular}

Voor een keurmerk zijn de indicatoren als volgt te bepalen

1. Inputindicator $=$ eisen die het keurmerk aan het bedrijf stelt

2. Outputindicator $=$ aandeel deelnemers aan het keurmerk en areaal (ha) dat overeenkomstig het keurmerk wordt beheerd

3. Outcome bedrijf = effect van het keurmerk op het bedrijf; (ecosysteemdiensten, biodiversiteit, abiotische condities, inzet productiefactoren, omzet)

4. Outcome omgeving = impact op de omgeving (is niet gelijk aan de aggregatie van effect op bedrijfsniveau)

5. Impactindicator = impact op doel keurmerk (wordt het doel gerealiseerd of niet).

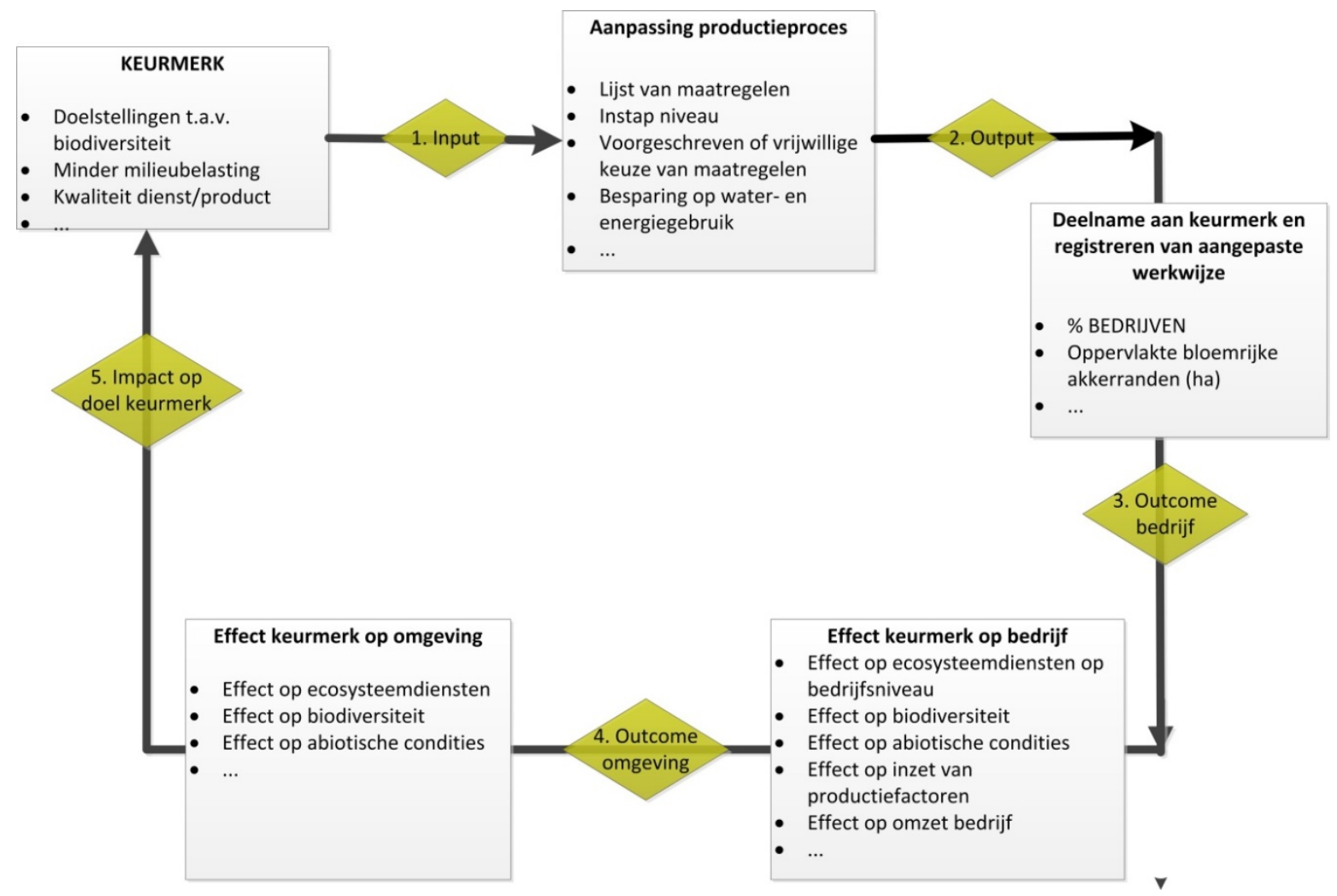

Figuur 3.5 Relaties in natuurinclusieve economie op basis van een keurmerk. De mogelijk te kwantificeren relaties (met daarin de onderscheiden indicatoren) zijn aangegeven 


\section{$4 \quad$ Uitwerking naar sectoren}

In dit hoofdstuk worden van deze drie keurmerken (die drie verschillende sectoren betreffen) de natuurinclusieve maatregelen geanalyseerd, wordt de keuze voor juist deze maatregelen en het mogelijk effect ervan beschouwd. Deze analyse bestaat uit een deskstudie en interviews met instanties die het keurmerk uitgeven.

Deskstudie groepen maatregelen

De deskstudie heeft als doel om inzichtelijk te maken welke (potentiele) impact de maatregelen (om aan criteria van keurmerken te voldoen) hebben op biodiversiteit en ecosysteemdiensten. Hierbij wordt bij biodiversiteit meer gekeken naar de intrinsieke waarde van (bedreigde of beschermde) soorten. In de deskstudie zijn niet alle afzonderlijke maatregelen van keurmerken meegenomen. Groepen maatregelen zijn, conform de indeling van GRI4, ondergebracht in de volgende categorieën van criteria: biodiversiteit, energie, water, materialen, emissies, producten/services. Op deze wijze is gefocust op criteria die een direct verband hebben met biodiversiteit en/of ecosysteemdiensten. Criteria op het gebied van communicatie, management, medewerkers en maatschappelijke betrokkenheid zijn niet meegenomen.

I mpact is positief, negatief of onduidelijk

Van de relevante criteria is door middel van expert judgement bepaald welke mogelijke impact ze hebben op biodiversiteit en/of ecosysteemdiensten. Impact kan positief zijn, negatief of onduidelijk. Een effect is onduidelijk als een criterium zodanig ruim opgevat kan worden dat maatregelen verschillende effecten of geen effect kunnen hebben Bij biodiversiteit is gefocust op soorten van flora en fauna (zie figuur 2.1), en niet op vee en gewassen. Criteria van keurmerken die betrekking hebben op biodiversiteit, gaan vaak over de aanleg of beheer van leefgebied voor flora en fauna, zoals natuurvriendelijk beheer van slootkanten of het creëren van nestgelegenheid. Er zijn ook criteria die betrekking hebben op de milieucondities die van invloed zijn op de kwaliteit van leefgebieden, zoals het beperken van het gebruik van pesticiden bij groenbeheer. Deze criteria worden apart vermeld. Voor biodiversiteit zijn de indicatoren gebaseerd op de GRI4-categorieën die genoemd zijn in tabel 2.4 (informatie, impact, herstel en overige). Voor ecosysteemdiensten zijn producerende, regulerende en culturele diensten meegenomen die genoemd zijn in tabel 2.2.

Kwalitatieve en kwantitatieve criteria

Criteria van keurmerken kunnen kwalitatief van aard zijn, zoals het hebben van een beheerplan voor het groen op het bedrijf of het inhuren van een gecertificeerde hovenier. Aan de hand van kwalitatieve criteria kan ingeschat worden of er een potentieel (positief of negatief) effect is, maar zonder verdere informatie kan de omvang van het effect niet ingeschat worden. Criteria worden kwantitatief als duidelijk is wat de omvang en/of duur van activiteiten zijn. Dat geeft een betere indicatie van mogelijke effecten op soorten, leefgebied, abiotiek of ecosysteemdiensten. Dan nog is er niet altijd een directe relatie tussen criteria en effecten. Als een bedrijf bijvoorbeeld nog maar de helft van de pesticiden gebruikt, is het nog niet meteen duidelijk wat daarvan precies het effect is op het voorkomen van soorten, de kwaliteit van het leefgebied of het leveren van de dienst natuurlijke plaagbestrijding. Het is belangrijk onderscheid te maken tussen criteria die alleen het bedrijfsterrein beslaan of criteria die ook betrekking hebben op de omgeving van het bedrijf. Naarmate criteria beter aansluiten op soorten en leefgebieden die in de omgeving voorkomen, kan het terrein van het bedrijf fungeren als verbinding tussen natuurgebieden in plaats van dat ze een barrière vormen. Door deze verbinding dragen ze bij aan het natuurlijk kapitaal.

Geen onderscheid verplichte en optione criteria

In principe is er geen onderscheid gemaakt tussen criteria die verplicht of optioneel zijn. Wel is het zo dat verplichte criteria meer worden toegepast omdat alle aangesloten bedrijven hieraan moeten voldoen (de outputindicator is groter), terwijl optionele criteria alleen impact hebben als een bedrijf een contract met een hoger ambitieniveau heeft afgesproken (de outcome indicator op de omgeving per eenheid optionele maatregel is groter). 


\subsection{Landbouw}

\subsubsection{Keurmerk Blief}

Blief is een keurmerk voor agrariërs die willen bijdragen aan een mooier platteland, door het aanleggen en beheren van natuur- en landschapselementen. Blief is ontwikkeld middels een samenwerking van boeren, onderzoekers en duurzaamheidsexperts. Initiatiefnemers zijn de Rietgors (Stichting voor Agrarisch Natuurbeheer in de Hoekse Waard), CREM, Nederlands Agrarisch J ongeren Kontakt (NAJK) en Stichting Milieukeur (SMK).

Onderscheidende marktkansen

Blief is begonnen als het 'Biodiversiteit+'-label, met als doel om (onderscheidende) marktkansen te creëren voor agrariërs die bewust aandacht besteden aan biodiversiteit tijdens de productie. Dit middels een afzetstrategie voor gecertificeerde producten, waarbij de markt meebetaalt voor 'groen' natuur- en landschapsbeheer. Blief draagt bij aan de natuurontwikkeling op het agrarisch bedrijf en het behoud van diersoorten als vogels, vlinders, bijen en soortenbehoud van cultuurhistorische rassen. Op zo'n manier draagt Blief bij aan de biodiversiteit.

\section{Certificeren}

Agrarische bedrijven kunnen hun producten laten certificeren voor Blief. SMK heeft met onafhankelijke certificatie-instellingen een licentieovereenkomst gesloten voor de certificering van Blief. Deze instellingen voeren de controles uit op basis van de certificatieschema's van SMK. Controle en certificering vinden plaats volgens Europese standaarden.

\section{Stappen}

1. Het bedrijf vraagt offertes aan bij één of meerdere certificatie-instellingen die een licentie hebben met SMK.

2. Op basis van de offerte(s) geeft de onderneming aan één van de certificatie-instellingen de opdracht.

3. De certificatie-instelling verzoekt het Blief-dossier aan hen te overleggen. De certificatie-instelling controleert het aangeleverde dossier en doet een audit op het bedrijf voor de aangegeven onderdelen van het certificatieschema.

4. Als de certificatie instelling vaststelt dat de producten voldoen aan de criteria, ontvangt de ondernemer het Blief-productcertificaat. Vervolgens is er elk jaar een herkeuring.

Houd het simpel

Voor wat betreft de certificering: SMK streeft ernaar om zijn maatlatten zo praktisch mogelijk te houden, zodat deze relatief eenvoudig zijn in te vullen. Ook Blief is zo opgezet, dat het aansluit bij wat boeren weten en kunnen meten. De boodschap is dus: houd het simpel. De maatlat zoals hij er nu ligt, is goed doordacht en afgestemd met agrarische ondernemers, zodat hij aansluit bij de belevingswereld van boeren.

\subsubsection{Maatregelen in het keurmerk}

Blief heeft eisen ( 5 verplichte maatregelen en 8 optionele maatregelen) op de volgende thema's:

- verbeteren milieucondities in de landbouw

- verbeteren bodembeheer

- natuur- en landschapsbeheer

- weidevogelbeheer en aandacht voor akkervogels

- beheer van sloten en slootranden

- educatie

- behoud van zeldzame rassen planten en vee.

Deze laatste beschouwen we in deze studie als cultureel erfgoed, een culturele ecosysteemdienst. 
Voor certificering dienen bedrijven te voldoen aan alle verplichte maatregelen en het minimum aantal te behalen punten per hectare vanuit de keuzemaatregelen. De te behalen puntenscore is gekoppeld aan de oppervlakte van het bedrijf voor een bepaalde bedrijfstak. Voor akkerbouw- en vollegrondsgroenten is 1 punt per ha als minimum vastgesteld.

Alle Bliefmaatregelen zijn gericht op natuur op het bedrijf zelf, maar kunnen wel invloed hebben op de omgeving van het bedrijf.

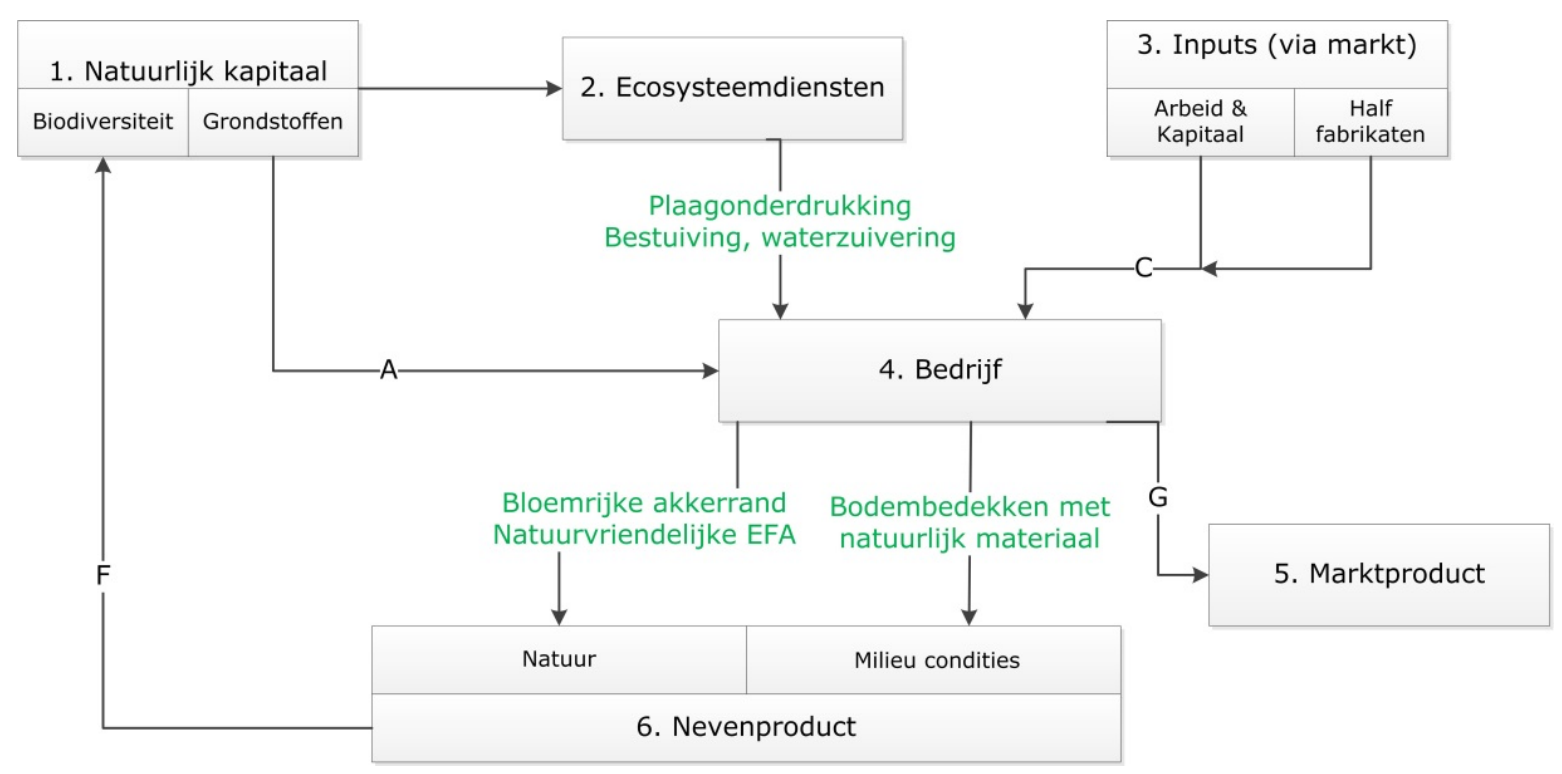

Figuur 4.1 Weergave van de Bliefmaatregelen in het raamwerk (figuur 3.1)

\subsubsection{Analyse Bliefmaatregelen}

Er zijn veel relaties gevonden tussen criteria van het keurmerk voor akkerbouw en vollegrondsgroenteteelt en indicatoren van biodiversiteit (zie tabel 4.1). De indicatoren zijn meestal kwalitatief. De meeste criteria hebben wel te maken met daadwerkelijk herstel van biodiversiteit via aanleg of beheer van leefgebied.

Meestal onduidelijke effecten

Het eerste verplichte criterium, 'voldoen aan de wettelijke eisen en een goede landbouw milieuconditie' stijgt niet uit boven de huidige praktijk en daarom heeft deze maatregel geen extra effect in het kader van natuurinclusieve economie. Het positieve effect van het tweede verplichte criterium, 'een certificaat SKAL, Milieukeur of een alternatief', is moeilijk in te schatten. Het draagt bij aan gunstige milieucondities in het leefgebied, maar levert niet daadwerkelijk meer leefgebied of soorten op. Het effect van het derde verplichte criterium 'voldoen aan vergroening GLB' is onduidelijk. Dit criterium leidt niet direct tot een toename van de biodiversiteit omdat permanent grasland niet geldt voor de akkerbouw, de voorwaarde 3 verschillende gewassen al gangbare praktijk is, en $5 \%$ EFA's (Ecological Focus Areas, uit het EU plattelandsbeleid) heel breed ingevuld kan worden, bijvoorbeeld met vanggewassen in plaats van met natuurlijk habitat. Het criterium van $5 \%$ natuurvriendelijke EFA draagt wel direct bij aan het leefgebied en is ook een kwantitatieve maatregel. Het vierde verplicht criterium gaat over de registratie van natuur, wat niet direct bijdraagt aan herstel van habitat of soorten, maar van belang is bij bijvoorbeeld monitoring.

Effecten optionele criteria

Bij de optionele criteria kunnen de opties natuurmaaisel als mest gebruiken, bodembedekking met natuurlijk materiaal en beperkte bodembewerking bijdragen aan herstel van abiotische condities, maar niet direct aan extra leefgebied of soorten. De optie van het herstel van nestgelegenheid heeft alleen zin als ander deelhabitat (voor foerageren bijvoorbeeld) ook voorhanden is. Het telen van zeldzame gewassen kan bijdragen aan voedselaanbod voor de fauna, maar dat hangt van het gewas af. Ook de 
opties oeverhabitat herstellen en de aanleg van kleine landschapselementen dragen direct bij aan het natuurlijk leefgebied. De optie van natuurvriendelijk beheer van akkers via beheerregelingen draagt bij aan het natuurlijk leefgebied, zeker gezien de voorwaarde dat voor het verkrijgen van een beheervergoeding akkers in, door de provincie begrensd, gebied moeten vallen. Dat levert een ruimtelijke meerwaarde, op regionaal niveau. Aangezien veel soorten, ook soorten die regulerende ecosysteemdiensten leveren zoals bestuivers en plaagbestrijders, aangewezen zijn op een netwerk van habitat dat boven het bedrijfsniveau uitstijgt, zou het een meerwaarde hebben als criteria binnen dit keurmerk extra beloond worden als ze in samenwerking met omliggende boeren, in ANV of collectief verband worden genomen.

In het keurmerk zijn 12 criteria gevonden die een potentieel effect hebben op de indicatoren van ecosysteemdiensten op het bedrijf (zie tabel 4.1). De meeste zijn optioneel en kwalitatief, met regelmatig een duidelijk positief effect. Natuurmaaisel, structuurrijke mest en bodem maatregelen (bodembedekking winter, beperken bodembewerking) verhogen het organische stofgehalte van de bodem en daarmee zowel de bodemvruchtbaarheid als de koolstofvastlegging. Het afdekken van de bodem met natuurlijk materiaal zoals maaisel, stro of compost, ook wel mulching genoemd, voorkomt ook verdamping en draagt zo bij aan waterregulatie. Dit kan echter ook nadelen met zich meebrengen: zo kan vooral in te natte omstandigheden bij een jaarronde bedekking een ondoordringbare laag of schimmel ontstaan, of kan het slakken aantrekken. Het creëren van nestgelegenheid voor honing- en wilde bijen en van plaagbestrijdende insecten draagt bij aan natuurlijke plaagbestrijding en bestuiving, mits ook aan andere eisen (foerageren, overwinteren en dergelijke) van deze insecten wordt voldaan. Dit bij voorkeur toegepast op een schaalniveau dat boven het bedrijf uitstijgt. Andere maatregelen, zoals de aanleg van EFA's, kleine landschapselementen of natuurvriendelijke oevers, leveren ook (bijdragen aan) ecosysteemdiensten. Natuurvriendelijke oevers kunnen bijdragen aan het reinigend vermogen van water. Deze oevers kunnen net als kleine landschapselementen en natuurlijke EFA's ook bijdragen aan het natuurlijke erfgoed en cultuurhistorische waarde van een gebied. Blief heeft een apart en kwantitatief criterium voor educatie, namelijk het rondleiden van minimaal 5 (school)groepen of 50 individuele bezoekers per jaar.

De effecten van het keurmerk Blief op biodiversiteit en ecosysteemdiensten zijn samengevat in tabel 4.1. In deze tabel is het aantal criteria vermeld dat effect heeft op indicatoren van biodiversiteit. De criteria zijn beschreven in paragraaf 4.1.2, en ingedeeld aan de hand van de bijbehorende GRI-4categorie. In het Bliefkeurmerk komen alleen criteria voor op het gebied van biodiversiteit op bedrijfsniveau. 


\begin{tabular}{|c|c|c|c|}
\hline \multirow{2}{*}{ Indicatoren } & \multirow[t]{2}{*}{ GRI-4 criteria } & \multicolumn{2}{|c|}{ biodiversiteit } \\
\hline & & Effect & $\begin{array}{c}\text { Aantal criteria met } \\
\text { potentieel effect }\end{array}$ \\
\hline informatie bedrijf/terrein & & $+/-$ & 1 \\
\hline \multirow[t]{4}{*}{ herstel habitats/soorten } & beschrijven ontwikkeling & & \\
\hline & uitvoering herstelactiviteiten & 0 & 1 \\
\hline & & $+/-$ & $6(a)$ \\
\hline & & + & $4^{*}$ \\
\hline \multirow[t]{6}{*}{ Regulatie } & zuivering water & + & 1 \\
\hline & plaagonderdrukking & $+/-$ & 2 \\
\hline & bestuiving & $+/-$ & 2 \\
\hline & koolstofvastlegging & + & 1 \\
\hline & bodemvruchtbaarheid & + & 2 \\
\hline & waterregulatie (verdamping tegengaan) & $+/-$ & 1 \\
\hline \multirow[t]{2}{*}{ Cultureel } & natuurlijk erfgoed & $+/-2$ & 2 \\
\hline & educatie & + & 1 \\
\hline \multicolumn{4}{|l|}{ Biodiversiteit } \\
\hline
\end{tabular}

Ecosysteem

diensten

Regulatie

zuivering water

$+1$

1

Er zijn alleen indicatoren van biodiversiteit en ecosysteemdiensten vermeld die beïnvloed worden door criteria van het keurmerk (zie ook tabel 2.4).

Effect: $+=$ positief, - = negatief, $+/-=$ onduidelijk, 0 = geen effect

Cijfer $=$ aantal criteria dat (potentieel) effect heeft op betreffende indicator

Grijs = criterium is kwantitatief

$*=$ enkele criteria zijn kwantitatief

$\mathrm{a}=$ herstel abiotiek in plaats van habitat

\subsubsection{Meetbaarheid van effecten maatregelen}

De maatlat voor Blief is gebaseerd op het meten van ecosysteemdiensten, niet op het meten van de impact op biodiversiteit. Het gaat dan bijvoorbeeld om het meten van natuur- en landschapselementen, niet om het aantal bijen, vlinders of vogels. Het betreft dus een inspanningsverplichting voor de boer, en geen resultaatverplichting.

Bestaande meetlatten en regelingen

Bij het bepalen van de invloed van bedrijven op de biodiversiteit heeft SMK gebruik gemaakt van al bestaande meetlatten en regelingen: de Gaia-biodiversiteitsmeetlat van CLM en het al wat oudere ANNA (Agrarisch Natuur Norm Analyse), ook van CLM; Programma Beheer en SAN; randvoorwaarden van GLB.

Daarnaast heeft Blief GLB-erkenning gekregen. Dat betekent dat agrariërs die voldoen aan de biodiversiteitscriteria van Blief, ook aan de GLB-vergroeningseisen voldoen. Ze ontvangen daarvoor een speciaal certificaat. 
Aantal deelnemers Blief

Er zijn drie bedrijven ingeschreven. Twee daarvan hebben zich voor het keurmerk gekwalificeerd en zijn nu certificaathouders, een fruitteler en een melkveehouder. Deze agrarische bedrijven hebben meegedraaid in een pilot. Ze hebben kosten gemaakt om aan de biodiversiteitscriteria te voldoen, maar die werden betaald vanuit het project. Wel namen ze de extra administratieve lasten voor eigen rekening. Vooralsnog is Blief nog niet op de markt. De melkveehouder levert zijn melk dan ook nog steeds voor dezelfde prijs aan FrieslandCampina, zijn 'groene' melk gaat dezelfde tank in als alle andere melk.

\subsubsection{Conclusie}

Binnen het keurmerk Blief bestaan er diverse criteria op het gebied van natuur- en landschapsbeheer, akkervogelbeheer, beheer van sloten en slootranden en behoud van zeldzame rassen van gewassen en vee. De criteria zijn zowel gericht op het verbeteren van de milieucondities als op het verbeteren van natuur en biodiversiteit. Het effect van maatregelen op natuur en biodiversiteit wordt niet gemeten. Het gaat om een inspanningsverplichting, er wordt gemeten in welke mate de maatregelen voldoen aan de criteria.

\subsection{Gastvrijheidsector}

\subsubsection{Keurmerk Green Key}

Green Key is een internationaal keurmerk voor duurzame bedrijven in de recreatie- en vrijetijdsbranche en zakelijke markt (gastvrijheidssector). Het doel van Green Key is het verduurzamen van de gastvrijheidssector. Bedrijven met het keurmerk Green Key spannen zich in om het milieu te sparen, zonder dat hun gasten inleveren op comfort en kwaliteit. Zij gaan daarbij een stap verder dan de vereisten van normale wet- en regelgeving. Tijdens nieuwbouw, verbouw of renovatie wordt rekening gehouden met milieu/duurzaamheid, met inbegrip van biodiversiteit. Bij dranken en voedselproducten gaat het erom, of het product aantoonbaar geproduceerd is met respect voor het behoud en duurzaam gebruik van de natuurlijke hulpbronnen.

Vrijwillige inzet

Met een Green Key-certificaat laat een ondernemer zien dat hij zich vrijwillig inzet om meer aan het milieu te doen dan dat de wet- en regelgeving van hem verlangt. Green Key is een middel voor een ondernemer om zijn duurzame imago aan zijn gasten, leveranciers, relaties en overheden te uiten. Voor alle bedrijven geldt dat zij moeten voldoen aan alle verplichte Green Key-criteria (met normen) en een aantal optionele normen. De verplichte normen zijn basismilieunormen, zoals het registreren en besparen van gas, water en elektra en het verminderen van de hoeveelheid (rest)afval. De optionele normen gaan een stap verder. Hieronder vallen maatregelen zoals het gebruik maken van duurzame energie, het gebruik maken van zeepdispensers, of het zelf zuiveren van afvalwater. Daarnaast kent Green Key ook nog een lijst van bonusmaatregelen waaruit bedrijven ook kunnen kiezen. De score van het aantal optionele maatregelen bepaalt uiteindelijk welke niveau (brons, zilver of goud) het Green Key-certificaat van een bedrijf wordt, zie tabel 4.2.

Tabel 4.2 Maatregelen naar categorieën en de bijdrage aan het niveau van Green Key-keurmerk

\begin{tabular}{lll}
$\begin{array}{lll}\text { Type maatregel } \\
\text { Verplichte }\end{array}$ & Definitie & Criteria die de kleur van Green Key bepalen \\
maatregelen & $\begin{array}{l}\text { Maatregelen die alle deelnemende bedrijven } \\
\text { minimaal moeten nemen. }\end{array}$ \\
\hline $\begin{array}{l}\text { Additionele } \\
\text { maatregelen }\end{array}$ & $\begin{array}{l}\text { Maatregelen waaruit deelnemende bedrijven } \\
\text { mogen kiezen }\end{array}$ & $30 \%$ brons \\
\hline $\begin{array}{l}\text { Optionele } \\
\text { maatregelen }\end{array}$ & $\begin{array}{l}\text { Mogelijke maatregelen die kunnen meetellen bij } \\
\text { de additionele maatregelen }\end{array}$ & $\begin{array}{l}\text { Geen verplichting, maar tellen wel mee voor } \\
\text { behalen criterium }\end{array}$ \\
\hline
\end{tabular}


Green Key is het certificaat voor duurzame bedrijfsvoering van de internationale organisatie Foundation for Environmental Education (FEE). In Nederland wordt het Green Key-keurmerk beheerd door Stichting Keurmerk Milieu, Veiligheid en Kwaliteit (KMVK), (zie www.greenkey.nl). KMVK is een stichting opgericht door de organisaties RECRON, HISWA Vereniging, ANWB en Koninklijke Horeca Nederland (KHN). Naast Green Key beheert KMVK ook het keurmerk Blauwe Vlag, speciaal voor jachthavens.

KMVK heeft twee taken voor het keurmerk Green Key. Enerzijds ontwikkelt zij het classificatiesysteem voor haar keurmerk met daarin het onderscheid naar verplichte en optionele maatregelen. Eén keer in de drie jaar wordt het classificatiesysteem herzien. ${ }^{2}$ Maatregelen die wettelijk verplicht zijn geworden, worden uit de lijsten geschrapt. Additionele maatregelen kunnen verplicht worden. Anderzijds voert KMVK ook de tweejaarlijkse inspecties bij de deelnemende bedrijven uit. Ook organiseert KMVK jaarlijks een symposium voor de deelnemende bedrijven en adviseert het de deelnemende bedrijven op het gebied van duurzaamheid, milieu en MVO.

\subsubsection{Maatregelen keurmerk Green Key}

Green Key kent 3 maatregelen ( 9.1 tot en met 9.3 uit het keurmerk) gericht op biodiversiteit, onder de noemer 'groen en ruimte bedrijf', op een totaal van 88 maatregelen. Het gaat om de maatregelen: opstellen en uitvoeren van een groenbeheerplan in samenwerking met een deskundige of gecertificeerde hovenier (9.1, optioneel), onderhoud groenvoorzieningen met beperking van mest, pesticiden (9.2, verplichte maatregel) en bedrijfsnatuurplan dat een relatie met de omgeving heeft (9.3, optioneel).

Meeste maatregelen kwalitatief; effect vaak onduidelijk De meeste maatregelen zijn kwalitatief (opstellen van groenbeheerplan of bedrijfsnatuurplan) en de omvang van het effect is vaak onduidelijk. Onduidelijk wil zeggen dat het effect op biodiversiteit in principe positief is, maar dat de maatregelen zo breed zijn omschreven dat het werkelijke effect afhangt van hoe het betreffende bungalowpark de maatregel uitvoert. Ze hebben vaak betrekking op het beschrijven van de situatie. De criteria gaan doorgaans over het bedrijf zelf. Twee ervan zijn optioneel (zie tabel 4.2). Het enige verplichte criterium is minder milieubelastend groenonderhoud.

Energiebesparing en waterbesparing

Daarnaast kent Green Key twintig criteria voor maatregelen rond energiebesparing en zeven rond waterbesparing. De drie maatregelen op het gebied van afvalscheiding, de zeven rond schoonmaak en de twaalf rond voedsel en drank, hebben we geschaard onder de GRI-noemer 'emissies' (zie tabel 4.3). Onder de noemer 'products and services' zijn drie maatregelen gevonden rond vervoer en elf maatregelen rond gebouwen en leveranciers. Een klein deel van deze criteria zijn verplicht.

\footnotetext{
2 De maatregelenlijsten moeten voldoen aan de internationale normen van Green Key die weer vastgesteld zijn door de Executive Board van FEE en de International Steering Committee Green Key.
} 


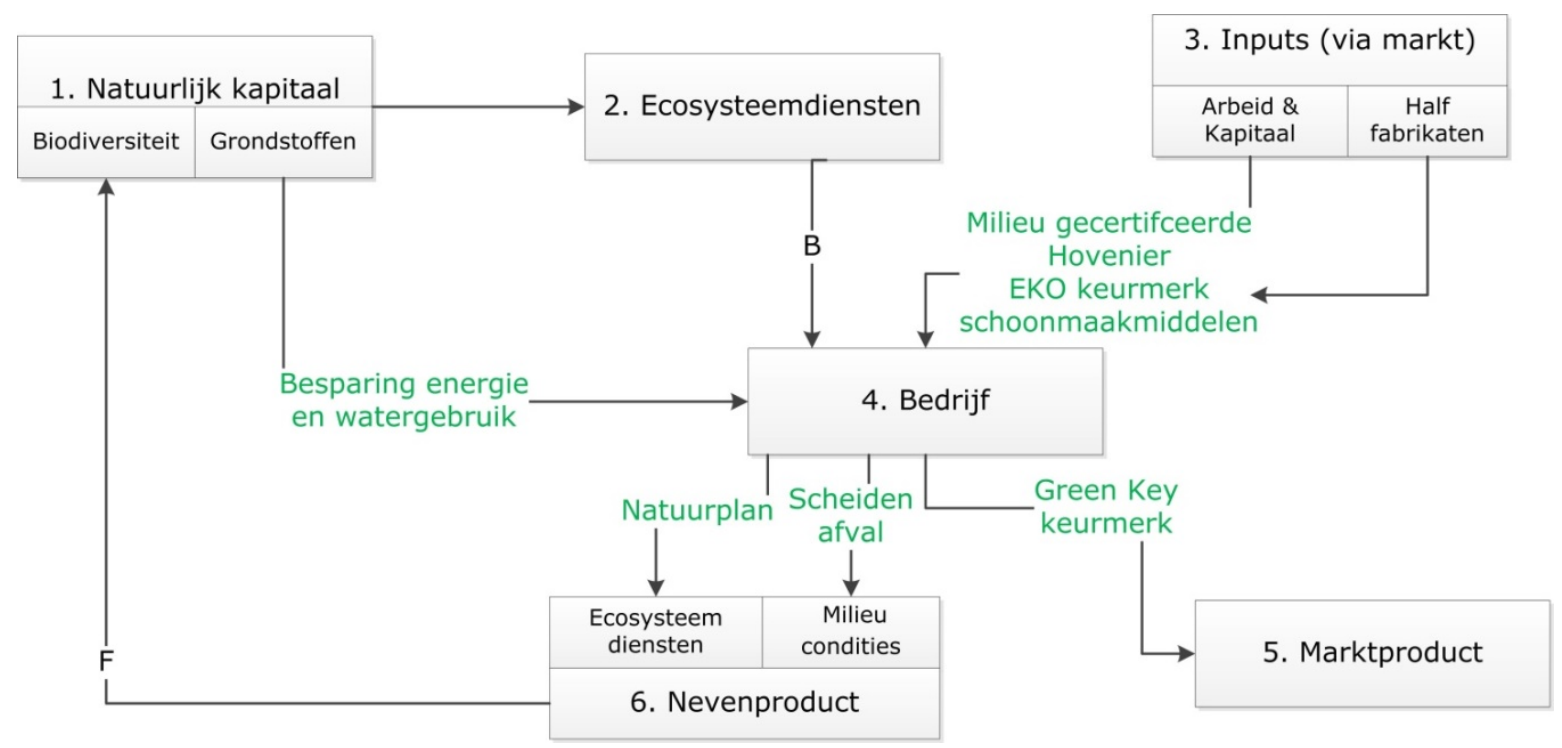

Figuur 4.2 Beschrijving van de Green Key maatregelen, gekoppeld aan het raamwerk

\subsubsection{Analyse maatregelen Green Key}

Het verplichte onderdeel 9.2, minder milieubelastend groenonderhoud is kwantitatief uitgewerkt en heeft een potentieel positief effect op de herstel van habitats of soorten via abiotiek (milieucondities) van leefgebied, maar hiermee is nog geen sprake van daadwerkelijk herstel van leefgebied of soorten binnen of buiten het bedrijf. Het effect is dus onduidelijk. Het optionele criterium 9.1 omvat het opstellen van een groenbeheerplan met een deskundige en/of het gebruik maken van een milieugecertificeerde hovenier. Bij minimale uitvoering leidt dit alleen tot minder milieubelastend onderhoud dat al gedekt wordt door het verplichte criterium. Het maken van een groenbeheerplan kan een positief effect hebben op de informatievoorziening rond biodiversiteit op het bedrijf of de omgeving en op herstel van biodiversiteit, maar dat hangt van de kwaliteit van het plan en van de uitvoering af. Ook is belangrijk welke deskundigheid hierbij betrokken wordt. De ecologische deskundigheid van een gecertificeerde hovenier of gemeenteambtenaar is niet gewaarborgd. Het tweede optionele criterium, het opstellen van een bedrijfsnatuurplan met een deskundige, heeft ook een relatie met de omgeving van het bedrijf en is ambitieuzer van opzet. Aannemende dat een ecologisch onderlegde deskundige betrokken wordt en de adviezen hiervan ook daadwerkelijk uitgevoerd worden, hebben we het effect als positief ingeschat. Maatregelen op het gebied van water, emissies en producten of diensten zouden kunnen bijdragen aan een betere abiotiek, dus aan een betere kwaliteit van leefgebieden, doordat deze maatregelen bijdragen aan een schonere bodem, lucht of (grond)wateren. Deze bijdragen aan lokale natuur zijn echter zeer onzeker omdat afvalwater en afval meestal worden afgevoerd van een bedrijf.

In het keurmerk is een aantal relaties gevonden tussen maatregelen om aan criteria te voldoen en indicatoren van ecosysteemdiensten op het bedrijf of in de omgeving. Dit zijn criteria op het gebied van biodiversiteit, namelijk minder milieubelastend groenonderhoud. Dit heeft een potentieel positief effect op het voorkomen van bestuivende en plaagbestrijdende insecten en draagt bij aan natuurlijke plaagonderdrukking en bestuiving. Er zijn veel maatregelen op het gebied van energie, water, emissies (afvalscheiding, schoonmaakmiddelen en voedsel) en op het gebied van producten/diensten (vervoer en gebouwen/leveranciers). Deze leiden wellicht wel tot een verminderde behoefte aan water/bodemzuivering, waterproductie en koolstofafvang, maar dragen zelf niet bij aan deze ecosysteemdiensten.

De effecten van het keurmerk Green Key op biodiversiteit en ecosysteemdiensten zijn samengevat in tabel 4.3. In deze tabel is het effect benoemd en het aantal criteria vermeld dat effect heeft op indicatoren van biodiversiteit. De criteria zijn beschreven in paragraaf 4.2.2, en ingedeeld aan de hand van de bijbehorende GRI-4-categorie. 
Tabel 4.3 Het effect en het aantal Green Key-criteria dat effect heeft op indicatoren van op biodiversiteit en ecosysteemdiensten. Criteria zijn beschreven in paragraaf 4.2.2 en ingedeeld in de bijbehorende GRI-4 categorie. Onderscheid is gemaakt of ze betrekking hebben op het bedrijf zelf of op de omgeving.

\begin{tabular}{|c|c|c|c|c|c|c|c|c|c|c|}
\hline Indicatoren & \multirow[t]{2}{*}{ GRI -4 criteria } & \multicolumn{2}{|c|}{ biodiversiteit } & \multicolumn{2}{|c|}{ biodiversiteit } & \multirow{2}{*}{$\begin{array}{l}\text { energie } \\
\text { bedrijf }\end{array}$} & \multirow{2}{*}{$\begin{array}{l}\text { water } \\
\text { bedrijf }\end{array}$} & \multirow{2}{*}{$\begin{array}{c}\text { emissies } \\
\text { bedrijf } \\
\text { Effect \& \#Criteria }\end{array}$} & \multirow{3}{*}{$\begin{array}{l}\text { productdienst } \\
\text { bedrijf } \\
\text { Effect \& \#Criteria }\end{array}$} & \multirow{3}{*}{$\begin{array}{l}\text { productdienst } \\
\text { omgeving } \\
\text { Effect \& } \\
\text { \#Criteria } \\
\end{array}$} \\
\hline & & \multicolumn{2}{|c|}{ bedrijf } & \multicolumn{2}{|c|}{ omgeving } & & & & & \\
\hline \multicolumn{2}{|l|}{ biodiversiteit } & Effect & $\begin{array}{c}\# \\
\text { Criteria }\end{array}$ & Effect & \# Criteria & & $\begin{array}{c}\text { Effect \& } \\
\text { \#Criteria }\end{array}$ & & & \\
\hline \multicolumn{2}{|l|}{ informatie bedrijf/terrein } & $+/-$ & 1 & $+1-$ & 2 & & & & & \\
\hline impact activiteiten & beperken negatieve impact & & & & & & $+/-1(a)$ & $+/-22(a)$ & $+/-11(\mathrm{a})$ & $+/-3(a)$ \\
\hline \multirow[t]{2}{*}{ herstel habitats/soorten } & beschrijven ontwikkeling & $+/-$ & 1 & $+/-$ & 1 & & & & & \\
\hline & uitvoering herstelactiviteiten & $+/-1$ & $1(a)$ & + & $1^{* *}$ & & & & & \\
\hline overige & inzet (externe) deskundige(n) & $+/-$ & 1 & + & 1 & & & & & \\
\hline \multicolumn{11}{|l|}{$\begin{array}{l}\text { ecosysteem } \\
\text { diensten }\end{array}$} \\
\hline \multirow[t]{3}{*}{ regulatie } & plaagonderdrukking & + & 1 & & & & & & & \\
\hline & bestuiving & +1 & 1 & & & & & & & \\
\hline & koolstofvastlegging & & & & & & & & & \\
\hline
\end{tabular}

Er zijn alleen indicatoren van biodiversiteit en ecosysteemdiensten vermeld die beïnvloed worden door criteria van het keurmerk (zie ook tabel 2.4)

Effect: $+=$ positief, - = negatief, $+/-=$ onduidelijk

cijfer $=$ aantal criteria die (potentieel) effect hebben op betreffende indicator

Grijs = criterium is kwantitatief

** = aannemende dat adviezen deskundige uitgevoerd worden

$\mathrm{a}=$ herstel abiotiek in plaats van habitat 


\subsubsection{Meetbaarheid effecten maatregelen}

Het keurmerk Green Key is gebaseerd op de inspanningen die deelnemende bedrijven doen ten aanzien van de maatregelen. Dit betekent dat er met name input (zie figuur 3.2) wordt geregistreerd door KVMK. De inspectie van het keurmerk bestaat dus uit het in kaart brengen welke maatregelen wel en niet genomen worden. Deze informatie wordt door KMVK verzameld maar niet gedeeld.

Er worden gegevens over het verbruik en de kosten van gas, water en elektriciteit bijgehouden door KVMK. Ook de omvang en de kosten van het afval wordt bijgehouden. De kostenbesparing van minder verbruik en minder afval zijn zichtbaar voor de ondernemer. Deze gegevens worden verzameld ten behoeve van de inspectie van deelnemende bedrijven, maar niet systematisch in een databestand gezet. Bedrijfseconomische informatie wordt verder ook niet bijgehouden. Als een ondernemer mvo wil zijn, zou hij ook eisen moeten stellen rond mvo van zijn toeleveranciers.

In oktober 2015 zijn er 638 bedrijven en organisaties die het keurmerk Green Key voeren. ${ }^{3}$ Dit is een output indicator zoals gedefinieerd in figuur 3.2. Meer dan $70 \%$ van de deelnemende bedrijven heeft een gouden Green Key. Twintig procent van de bedrijven heeft een zilveren Green Key.

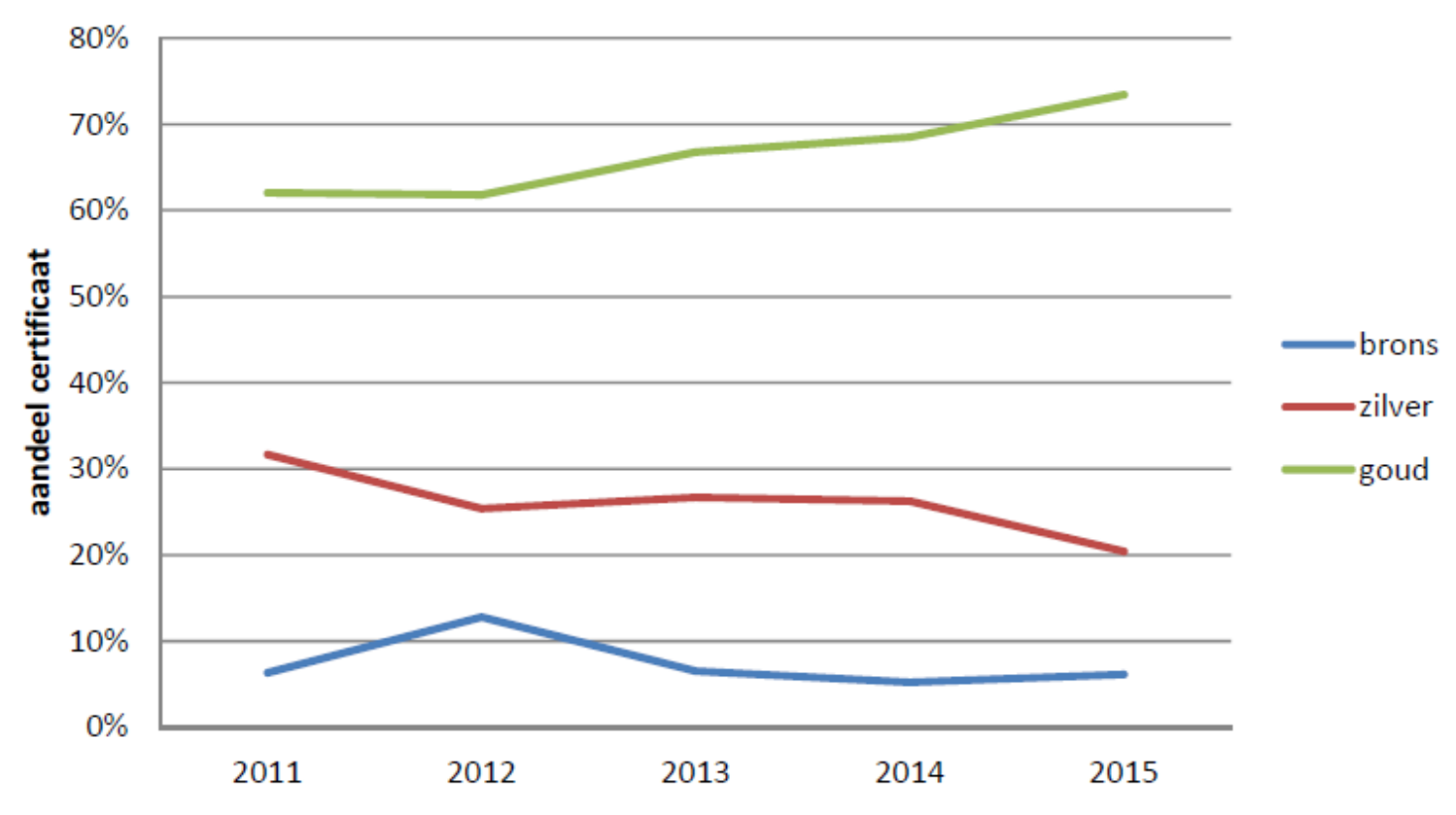

Figuur 4.3 Verdeling van gouden, zilveren en bronzen Green Key-bedrijven tussen 2011 en 2015 Bron: FEE Nederland (2015).

Verdere optimalisering milieu-inspanningen

Met de Green Key-benchmark probeert stichting KMVK bedrijven te stimuleren hun milieu-

inspanningen verder te optimaliseren, zie Nieuwsbrief KMVK voorjaar (2015). De benchmark toont aan dat hotels en bungalowparken met het Green Key-keurmerk in de periode 2011-2013 gemiddeld 9,8\% van hun $\mathrm{CO}_{2}$-uitstoot reduceerden en dat is hoger dan het landelijke gemiddelde (CLO, 2015). Bij campings ligt de $\mathrm{CO}_{2}$-reductie zelfs gemiddeld op $12,3 \%$. De reductie van $\mathrm{CO}_{2}$ is gerealiseerd door maatregelen te nemen zoals energiezuinige verlichting, slimme luchtbehandelingssystemen, herwinning van energie, groen gas en elektriciteit, isolatie, lichtsensoren, daglichtsystemen enzovoort. De gemiddelde reductie van $\mathrm{CO}_{2}$-uitstoot, energie- en waterverbruik en de hoeveelheid afval zijn ook output indicatoren zoals gedefinieerd in figuur 3.2. Dit zijn output indicatoren voor abiotische randvoorwaarden van biodiversiteit. Biodiversiteitsindicatoren voor output worden verder niet gemeten.

\footnotetext{
3 Eind 2014 waren 602 bedrijven met het keurmerk Green Key, zie FEE Nederland (2015). Fee Nederland Jaarverslag 2014.
} 
Persoonlijke benchmark

Alle deelnemers aan Green Key beschikken over een persoonlijke benchmark waarmee zij energie- en milieu-inspanningen van hun accommodatie kunnen afzetten tegen die van andere deelnemende bedrijven. KMVK merkt dat hierdoor een soort competitie ontstaat tussen deelnemende bedrijven, en vindt de benchmark een goed sturingsinstrument voor duurzaam én kostenbesparend ondernemen.

Geen systematische meting

Indicatoren voor outcome (figuur 3.2) die effecten van maatregelen op het bedrijf of de omgeving van het bedrijf meten, worden niet systematisch gemeten. Ook worden impact indicatoren die de bijdrage van maatregelen aan natuur en biodiversiteit in beeld kunnen brengen niet gemeten. $\mathrm{Er}$ is geen behoefte aan. KMVK is terughoudend in het meer meetbaar maken van de effecten van maatregelen op biodiversiteit. Dit betekent namelijk een hogere administratieve last voor de deelnemende bedrijven. Hiermee wordt het deelnemen aan het keurmerk Green Key minder aantrekkelijk.

Landal GreenParks: keurmerk geen doel maar middel Het Green Key-keurmerk is voor Landal GreenParks (Landal) geen doel maar een middel om de verschillende parken te verduurzamen. Inmiddels zijn er 40 parken met het keurmerk Green Key. In 2017 moeten alle Landalparken het keurmerk Green Key hebben. Doordat sommige parken autonoom geleid worden, kan niet worden afgedwongen dat dit ook daadwerkelijk wordt gerealiseerd. Landal gebruikt sowieso het groene imago om zich te onderscheiden van andere vakantieparken. Bij de locatie van de Landal-parken wordt rekening gehouden met de locatie. Parken worden gesitueerd naast of vlakbij natuurgebieden onder beheer van Natuurmonumenten of Staatsbosbeheer. Daarbij streeft Landal alleen naar vergroening van de parken en niet van hun omgeving. Zo worden de uitheemse soorten op de parken langzamerhand vervangen door inheemse soorten. Aangezien een aanzienlijk deel van de Landalparken al een keurmerk Green Key heeft, worden input- en een aantal outputindicatoren (zie figuur 3.2) benodigd voor het keurmerk Green Key gemeten. Landal geeft aan dat het meten van indicatoren alleen interessant voor het bedrijf is als er een relatie gelegd kan worden met de verbetering van de klanttevredenheid of de werknemerstevredenheid. Ook voor Landal staat een gezonde bedrijfsvoering op de eerste plaats. Landal is zich er wel van bewust dat het groen imago ook gestaafd moet zijn op bewijs.

De indicatoren die in het kader van de inspectie van Green Key worden gemeten worden centraal verzameld. Landal streeft naar strategische samenwerking met natuurbeheerorganisaties. Landal organiseert wandelingen en begeleide excursies in gebieden van Natuurmonumenten en Staasbosbeheer.

\subsubsection{Conclusie}

Het keurmerk Green Key helpt bedrijven (in beperkte mate) met het integreren van natuur en biodiversiteit in de bedrijfsvoering. Het keurmerk is voornamelijk gericht op het verbeteren van de abiotische omstandigheden (milieu). Maatregelen op het gebied van natuur en biodiversiteit zijn beperkt opgenomen in de lijst met maatregelen. Inputindicatoren worden gemeten omdat de criteria van het keurmerk daarop gebaseerd zijn. Zowel KMVK als Landal geeft aan dat het kader beperkt bruikbaar is voor individuele bedrijven, omdat het criterium van het keurmerk is verbonden met een inspanningsverplichting. Meer meten leidt tot meer administratieve lasten en dat is alleen interessant als het bijdraagt aan meer inzicht op een verbetering van de klanttevredenheid en/of de werknemerstevredenheid.

Aandeel bedrijven met keurmerk zeer klein Het aandeel bedrijven in de gastvrijheidssector met het keurmerk Green Key is minder dan $1 \%$. Aangezien vooral grote bedrijven het keurmerk hebben, is het aandeel in de omzet groter. Natuur en biodiversiteit zijn slechts in een beperkt aantal maatregelen vertegenwoordigd. De deelnemende bedrijven zien zelf op dit moment geen noodzaak om meer te gaan meten. 


\subsection{Bouw (BREEAM-NL)}

\subsubsection{Keurmerk BREEAM-NL}

BREEAM staat voor Building Research Establishment Environmental Assessment Method en is een beoordelingsmethode om de duurzaamheidprestatie van gebouwen te bepalen. De methode omvat vier verschillende keurmerken. Allereerst BREEAM-NL Nieuwbouw en Renovatie, dat sinds september 2009 operationeel is. Het wordt gebruikt om de duurzaamheidprestatie te bepalen van nieuwe gebouwen. Het tweede keurmerk is BREEAM-NL In-Use. Dit beoordeelt bestaande gebouwen op drie niveaus: Gebouw, Beheer en Gebruik. Dit is in de zomer van 2011 operationeel geworden. Het derde keurmerk BREEAM-NL Gebiedsontwikkeling beoordeelt de duurzaamheidprestatie van een gebiedsontwikkeling. Vanaf september 2011 is ook dit keurmerk operationeel. In 2013 lanceerde de DGBC het keurmerk BREEAM-NL Sloop en Demontage om de duurzaamheid van sloopprojecten te beoordelen. Gebouwen die niet in deze categorieën vallen, kunnen met een maatwerktraject worden beoordeeld: BREEAM-NL 'Bespoke' (zie BREEAM-NL, 2015). In deze rapportage ligt de focus op BREEAM-NL Nieuwbouw en Renovatie, het oudste en verreweg meest gebruikte keurmerk binnen BREEAM-NL.

Internationaal keurmerk BREEAM werd oorspronkelijk ontwikkeld en geïntroduceerd door het Building Research Establishment (BRE), een Engels onderzoeksinstituut. De Dutch Green Building Council (DGBC) heeft met hulp van marktpartijen deze richtlijn geschikt gemaakt voor de Nederlandse markt. Daarom is ook NL toegevoegd aan het keurmerk. Daarmee is de DGBC een 'National Scheme Operator'. Naast Nederland hebben ook Noorwegen, Spanje, Groot-Brittannië, Duitsland, Zweden en Oostenrijk het BREEAMkeurmerk geschikt gemaakt voor de eigen wet- en regelgeving (zie BREEAM-NL, 2015).

\section{Hoge kwaliteitsstandaard}

De BREEAM-NL-keurmerken zijn mede tot stand gekomen met medewerking van participanten van de DGBC. In speciale adviesgroepen worden de keurmerken doorontwikkeld. In stuurgroepen worden nieuwe keurmerken ontwikkeld. Het College van Deskundigen ziet toe op de kwaliteit van de keurmerken. De DGBC als ontwikkelaar en beheerder van de BREEAM-NL keurmerken werkt onder licentie van de UKAS-accreditatie verleend aan BRE Global. Hiermee is een hoge kwaliteitstandaard gewaarborgd (zie BREEAM-NL, 2015). De eisen van BREEAM-NL liggen hoger dan wettelijk vereist. Als de wet wordt aangescherpt, veranderen de eisen in BREEAM-NL mee.

Andere keurmerken voor gebouwen

BREEAM-NL is niet het enige duurzaamheidskeurmerk voor gebouwen dat in Nederland gebruikt wordt. Andere keurmerken zijn bijvoorbeeld het Energielabel, de EPC-norm, GreenCalc, GPR-Gebouw, Eco-Quantum en LEED. De DGBC streeft naar harmonisatie met de andere systemen. Het energielabel en de EPG zijn wettelijk verplicht en inmiddels volledig geïntegreerd in BREEAM-NL (zie BREEAM-NL, 2015).

\section{Assessmentproces}

Een volledige BREEAM-NL assessment vindt in hoofdlijnen plaats volgens onderstaand proces:

- Een project wordt in de DGBC-assessmenttool aangemaakt.

- Het project wordt formeel tegen een beoordelingsrichtlijn-versie (BRL) geregistreerd in de

- assessmenttool. Er wordt een registratietarief in rekening gebracht door DGBC.

- Het project krijgt een uniek geïdentificeerd registratienummer toegekend.

- Het project bereidt het assessmentrapport voor.

- Een geregistreerd assessor voert kwaliteitscontrole uit en stelt de score vast.

- DGBC voert steekproefsgewijze controles uit op het eindoordeel van de assessor.

- Na afdoende voltooiing wordt er een certificaat afgegeven.

Bij ieder deelonderwerp of credit zijn punten te verdienen door te voldoen aan een van de criteriaeisen. Dit dient de deelnemer te onderbouwen met bewijsmateriaal. Er kunnen punten worden behaald in negen verschillende duurzaamheidscategorieën. Deze categorieën hebben ieder een eigen weging: management $(12 \%)$, gezondheid $(15 \%)$, energie $(19 \%)$, transport $(8 \%)$, water $(6 \%)$, materialen 
$(12,5 \%)$, afval $(7,5 \%)$, landgebruik \& ecologie $(10 \%)$ en vervuiling $(10 \%)$. De gewogen categoriescores worden opgeteld om de totaalscore te berekenen op een schaal van $0 \%$ tot $100 \%$. Deze totaalscore geeft de duurzaamheid van het totale gebouw weer. Overigens is een totaalscore van $100 \%$ theoretisch niet haalbaar, omdat er ook credits zijn die elkaar tegenspreken. De totaalscore in procenten kan vervolgens worden vertaald naar een classificatie in woorden en in sterren (Wormgoor, 2013). Hierbij is 1 ster het laagste ambitieniveau (Pass) en 5 sterren het hoogste (Outstanding).

Tabel 4.4 BREAAM-score op basis van totaalscore

\begin{tabular}{lll} 
Aantal sterren & Oordeel & Benodigde BREAAM totaalscore \\
$*$ & Pass & $\geq 35 \%$ \\
\hline$* *$ & Good & $\geq 45 \%$ \\
\hline$* * *$ & Very Good & $\geq 55 \%$ \\
\hline$* * * *$ & Excellent & $\geq 70 \%$ \\
\hline$* * * * *$ & Outstanding & $\geq 85 \%$ \\
\hline
\end{tabular}

Bron: Wormgoor (2013).

\subsubsection{Maatregelen}

Maatregelen zijn in BREEAM-NL de acties die de deelnemer onderneemt om te voldoen aan de criteriaeisen van het keurmerk. Zoals gebruikelijk bij een keurmerk, is er niet vastgelegd welke maatregelen genomen moeten worden, maar aan welke criteria-eisen moet worden voldaan.

Zeven criteria 'Landgebruik en Ecologie'

Een deelnemer kan punten behalen op deelonderwerpen van de negen duurzaamheidscategorieën die hierboven genoemd zijn bij 4.3.1. De zeven criteria onder de categorie 'Landgebruik en Ecologie' zijn van alle criteria het meest gericht op de impact op natuur en biodiversiteit. Het gaat om de volgende deelonderwerpen:

- LE 1. Hergebruik van land

Het stimuleren van projectontwikkelaars, gemeenten, woningbouwcorporaties en andere bouwende partijen om bouwprojecten te realiseren op een locatie met een lage ecologische en landschappelijke waarde en het stimuleren van hergebruik van al ontwikkelde grond, om wildgroei van gebouwen in het landelijke gebied te voorkomen.

- LE 2. Verontreinigde bodem

Het realiseren van bouwprojecten op locaties met verontreinigde bodem in plaats van op locaties met schone bodem.

- LE 3. Aanwezige planten en dieren op de bouwlocatie Het stimuleren van het treffen van maatregelen om planten en dieren die aanwezig zijn op de bouwlocatie te beschermen en behouden gedurende de bouw.

- LE 4. Planten en dieren als medegebruiker van het plangebied Het stimuleren van het treffen van inrichtingsmaatregelen ten behoeve van het duurzame medegebruik van het te ontwikkelen gebouw en de open ruimte door inheemse plant- en diersoorten.

- LE 6. Duurzaam medegebruik van planten en dieren op de lange termijn Het stimuleren van natuurvriendelijk beheer, onderhoud en natuurvriendelijke monitoring van het gebouw en de open ruimte, om het duurzame medegebruik van de onder LE 3 en LE 4 beoogde planten en dieren te garanderen.

- LE 8. Partnerschappen met een lokale natuurorganisatie Langdurig gebruik maken van de kennis van het lokale ecosysteem en lokale plant- en diersoorten, die aanwezig is bij lokale natuurorganisaties.

- LE 9. Efficiënt grondgebruik Het bevorderen van efficiënt grondgebruik door het beperken van het bebouwd oppervlak binnen de ontwikkeling. 


\section{LE 1 en LE 4 opvallend}

Van de projecten waarbij een credit gehaald kon worden voor een van de criteria van 'Landgebruik en Ecologie', zette meer dan 90\% van de deelnemers in op LE 1 en LE 4 (zie tabel 4.5). Met zo'n 80\% zijn ook LE 3 en LE 6 behoorlijk in trek. LE 2, LE 8 en LE 9 zitten daarentegen (ruim) onder de 10\% van het totaal aantal projecten. Dat betekent dat de populairste maatregelen op het gebied van landgebruik en ecologie op het hergebruik van land en het beschermen van planten en dieren liggen. Daarbij ligt het ambitieniveau voor het beschermen van planten en dieren met 1 of 2 punten wel laag. Bij het hergebruik van land (LE 1) ligt het ambitieniveau juist opvallend hoog (vier op de vijf projecten die de credit hebben behaald, heeft een niveau van 4 of 5 punten).

Tabel 4.5 Inzet van projecten op de criteria onder 'Landgebruik en Ecologie'

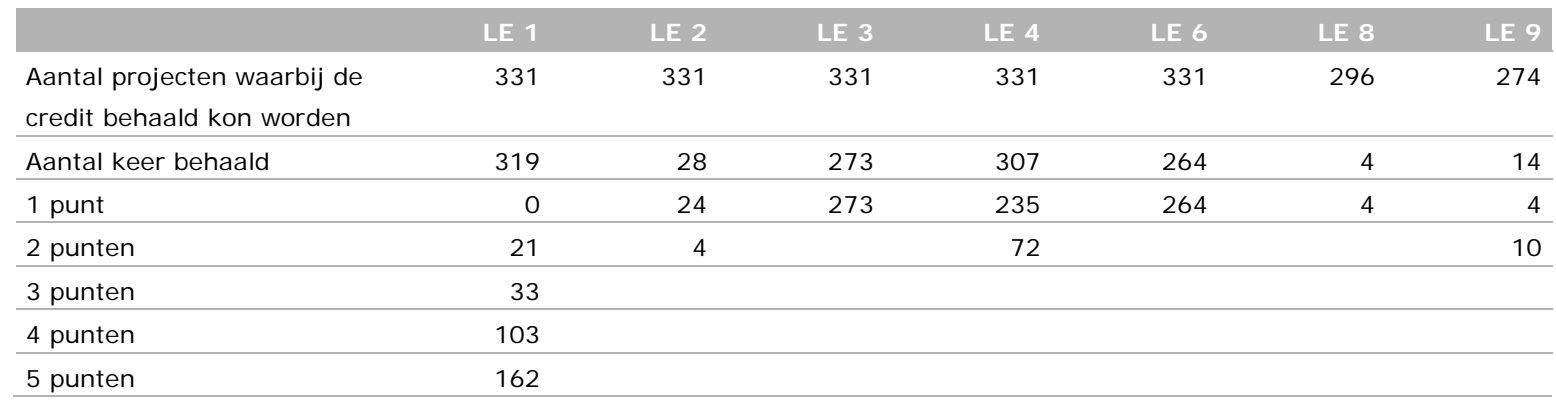

Bron: uitdraai van DGBC, 25 november 2015.

Andere categorieën

Verder kunnen maatregelen in andere duurzaamheidscategorieën, met name op het gebied van energie, transport, water, materialen, afval en vervuiling, in meer of mindere mate bijdragen aan betere milieucondities. Door bij te dragen aan een schonere bodem of lucht of schoner (grond)water, zorgen deze maatregelen mogelijk voor een betere kwaliteit van leefgebieden.

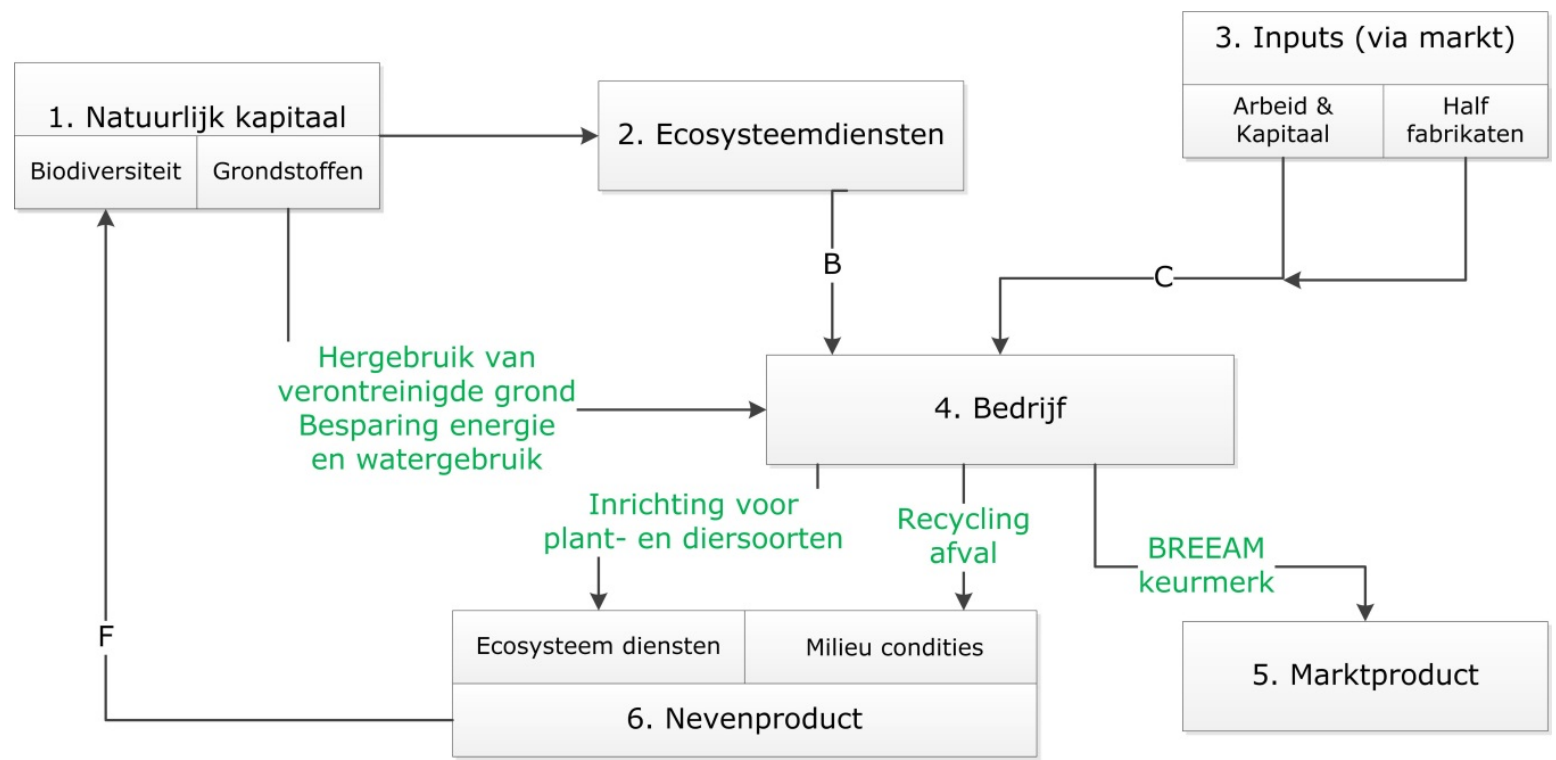

Figuur 4.4 Beschrijving van de BREEAM-NL maatregelen, gekoppeld aan het raamwerk

\subsubsection{Analyse maatregelen BREEAM}

Criteria zijn merendeels kwalitatief en deels kwantitatief. De meeste maatregelen om aan deze criteria te voldoen hebben een onduidelijk effect, dat wil zeggen dat er een potentieel positief effect is, maar dat de criteria zo kwalitatief en breed zijn omschreven dat het werkelijke effect afhangt van hoe het 
betreffende bedrijf de criteria hanteert op een bepaalde bouwplaats. Criteria LE1, LE2 rond locatiekeuze en LE3 rond bescherming flora/fauna tijdens de bouw hebben bijvoorbeeld een onduidelijk effect op de informatievoorziening rond biodiversiteit op het bedrijf en/of omgeving. Het beperken van het gebruiksoppervlak (LE9) is wel kwantitatief, en hebben wij als positief effect op de indicator 'informatie bedrijf/terrein' geschat, omdat dit meer ruimte biedt voor habitat flora en fauna. Ook de effecten van LE3 en van LE4 en LE 6 rond medegebruik van planten en dieren zijn niet direct duidelijk op positieve of negatieve impact op biodiversiteit. Wel is het zo dat in LE4 het beschermen van 3 soorten uit de Flora- en faunawet een extra bonuspunt oplevert. Dit heeft een duidelijker en ook kwantitatief effect. Ook gelden maatregelen in LE6 voor minimaal 6 jaar, wat de kans op een positief effect op biodiversiteit vergroot. Dat geeft wel weer aan dat andere maatregelen wel van erg korte duur kunnen zijn. De genoemde maatregelen gaan vooral over het maken van plannen om biodiversiteit te stimuleren. In LE3 zijn directe maatregelen voorzien in samenwerking met een ecoloog die negatieve impact op flora en fauna beperkt. Dit hebben we als positief effect aangemerkt, al is de maatregel niet kwantitatief en is niet duidelijk tijdens de monitoring wordt getoetst of plannen daadwerkelijk uitgevoerd worden of succesvol zijn. De op te stellen plannen, om biodiversiteit te stimuleren, leveren in ieder geval een belangrijke basis voor het monitoren van de effecten van (toekomstige) maatregelen, dat is voorzien in maatregel LE6 en LE9. Criteria LE3, LE4 en LE6 kunnen betrekking hebben op het bedrijf, maar ook op de omgeving ven een bedrijf of bouwlocatie.

Maatregelen op het gebied van water, materialen, emissies en producten of diensten zouden kunnen bijdragen aan een betere abiotiek (milieucondities), dus aan een betere kwaliteit van leefgebieden, door bij te dragen aan een schonere bodem of lucht, of schoner (grond)water (zie ook paragraaf 4.2.3 over Green Key maatregelen).

Geen relatie maatregelen en indicatoren In het keurmerk is een enkele relatie gevonden tussen maatregelen en indicatoren van ecosysteemdiensten op het bedrijf of in de omgeving. Het beperken van bebouwd oppervlak heeft namelijk een positief effect op waterregulatie omdat er meer onbedekt oppervlak is waar water in de bodem kan infiltreren. Het zoeken naar locaties met bodemverontreiniging (zie biodiversiteit) kan de bodemvervuiling beperken, zeker als er sprake is van bodemsanering, maar heeft geen positief effect op het reinigend vermogen van de bodem. Criteria op het gebied van energie, water, materialen, emissies en transport kunnen wel de behoefte aan koolstofvastlegging, waterproductie en/of zuivering, houtproductie, bodenzuivering en waterregulatie verminderen, maar vergroot de levering van deze ecosysteemdiensten niet.

De effecten van BREEAM op biodiversiteit en ecosysteemdiensten zijn samengevat in tabel 4.6. In deze tabel is het aantal criteria vermeld dat effect heeft op indicatoren van biodiversiteit. De criteria zijn beschreven in paragraaf 4.3.2, en ingedeeld aan de hand van de bijbehorende GRI-4-categorie. 


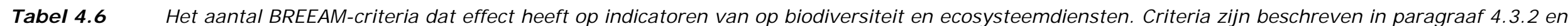
ingedeeld in de bijbehorende GRI-4 categorie, Onderscheid is gemaakt of criteria betrekking hebben op het bedrijf zelf of op de omgeving.

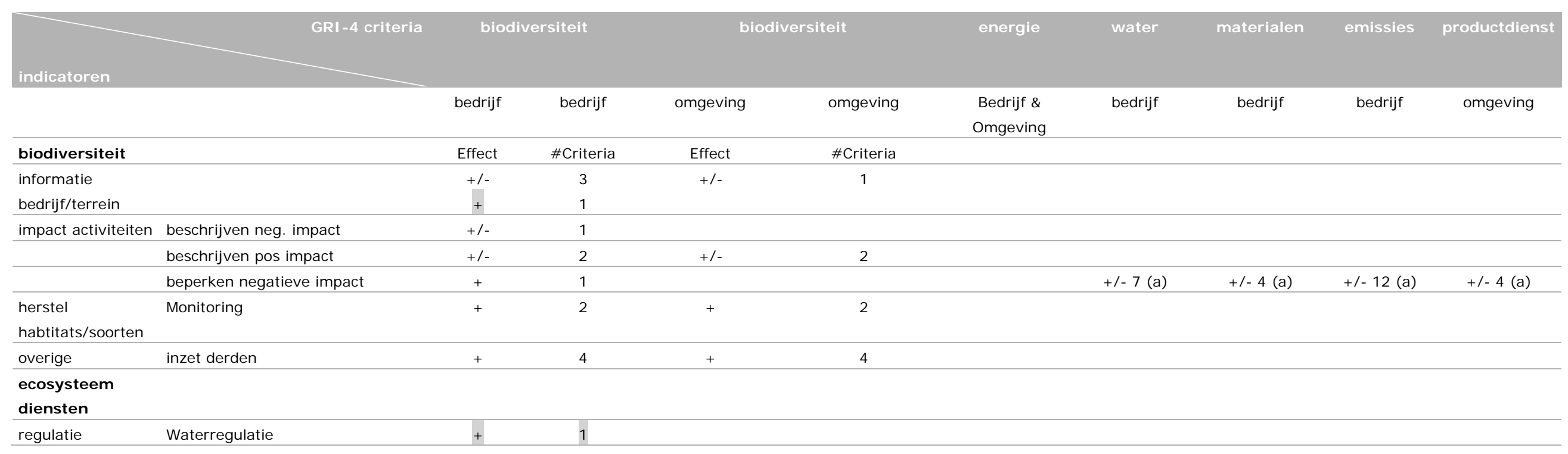

Er zijn alleen indicatoren van biodiversiteit en ecosysteemdiensten vermeld die beïnvloed worden door criteria van het keurmerk (zie ook tabel 2.4)

Effect: $+=$ positief, - = negatief, $+/-=$ onduidelijk

cijfer $=$ aantal criteria die (potentieel) effect hebben op betreffende indicator

Grijs $=$ criterium is kwantitatief

$a=$ herstel abiotiek in plaats van habitat 


\subsubsection{Meetbaarheid van effecten maatregelen}

Doel: bebouwde omgeving verduurzamen

Het doel van het keurmerk BREEAM-NL is om de bebouwde omgeving te verduurzamen. Dat is een veel breder doel dan het versterken van de natuur en biodiversiteit. Voor het keurmerk is belangrijk dat de assessor kan beoordelen of een bedrijf goed is omgegaan met de aanbevelingen van een ecoloog. Hij hoeft zelf niet ecologisch onderlegd te zijn. De assessor kan bij oplevering van een gebouw alleen meten of aan de criteria wordt voldaan; er wordt niet gecontroleerd of plannen daadwerkelijk zijn uitgevoerd en wat het effect daarvan is. Dat betekent dat de assessor niet zal meten in hoeverre de maatregelen voldoen aan de criteria-eisen en niet in welke mate de genomen maatregelen een effect hebben op ecologie.

Economische indicatoren worden niet direct gemeten. Wel heeft DGBC de ambitie om credits voor criteria in evenwicht te brengen met de nodige investeringen die een bedrijf hiervoor moet doen. Criteria moeten economisch haalbaar zijn, betaalbaar blijven en tegelijkertijd voldoende opleveren voor duurzaamheid. Informatie hierover krijgt de DGBC onder meer via de Adviesgroepen en het College van Deskundigen.

\section{Statistieken}

De DGBC houdt statistieken bij over het keurmerk BREEAM-NL Nieuwbouw en Renovatie in Nederland. Het aantal projecten dat bij DGBC staat geregistreerd wordt bijgehouden. Dit zijn alle projecten die sinds september 2009 hebben aangegeven met BREEAM-NL te willen certificeren, inclusief inmiddels gecertificeerde of geannuleerde projecten. In augustus 2015 zat het aantal registraties dicht tegen de 600 aan (zie figuur 4.5). Het gaat hierbij om zowel certificaten voor de ontwerpfase als voor de opleveringsfase. Dat betekent dat van één project zowel een ontwerpcertificaat als een oplevercertificaat in de figuur kan staan.

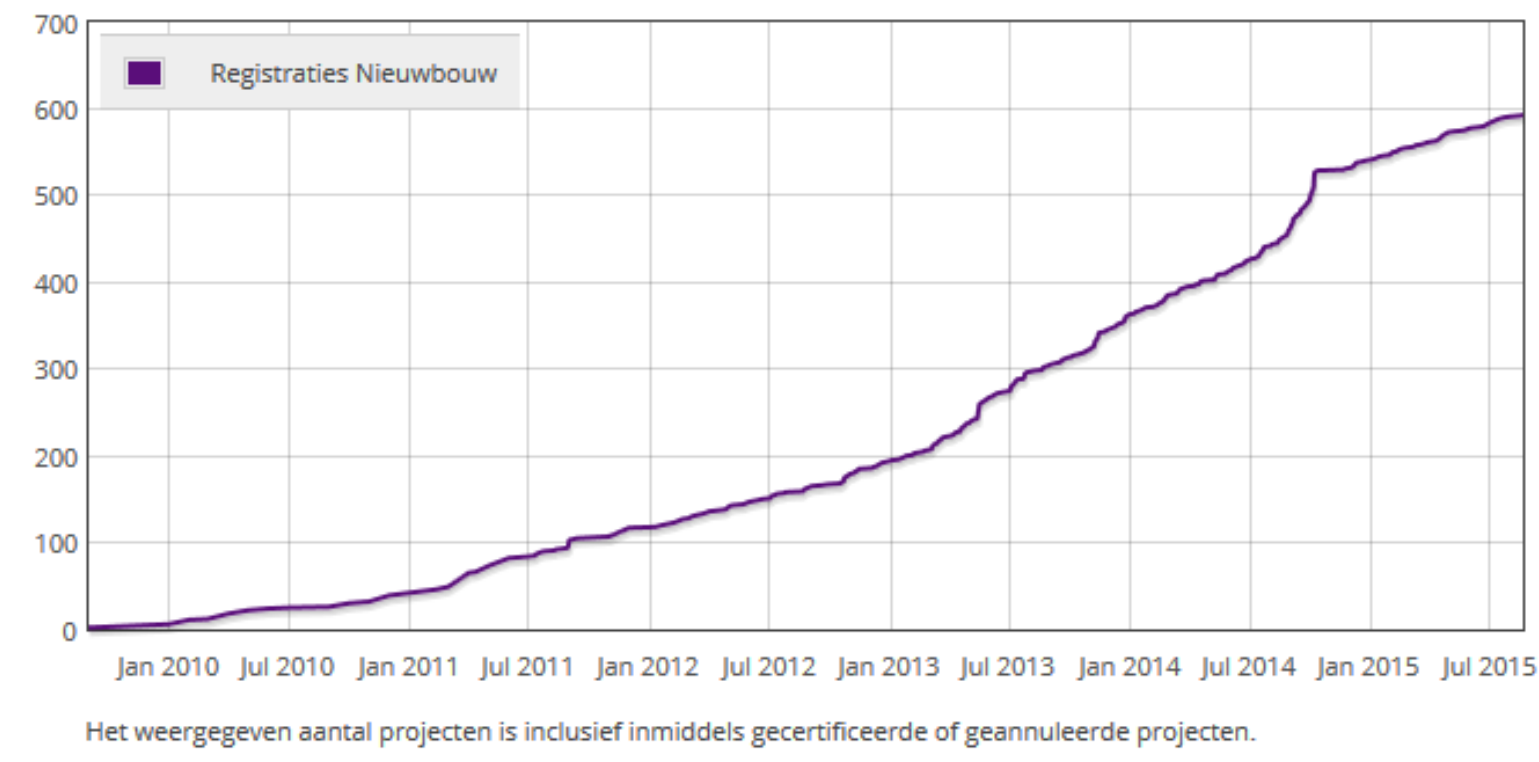

Figuur 4.5 Aantal registraties BREEAM-NL Nieuwbouw (cumulatief) Bron: BREEAM (2015).

Figuur 4.6 geeft het aantal $\mathrm{m}^{2}$ brutovloeroppervlakte (BVO) van projecten die bij de DGBC staan geregistreerd. De projecten kunnen inmiddels een BREEAM-NL-certificaat hebben of bezig zijn met een certificeringstraject. Het gaat daarbij om unieke registraties. Geannuleerde projecten, dubieuze registraties en mogelijke dubbelingen vanwege ontwerp- en opleverregistratie zijn eruit gefilterd. 


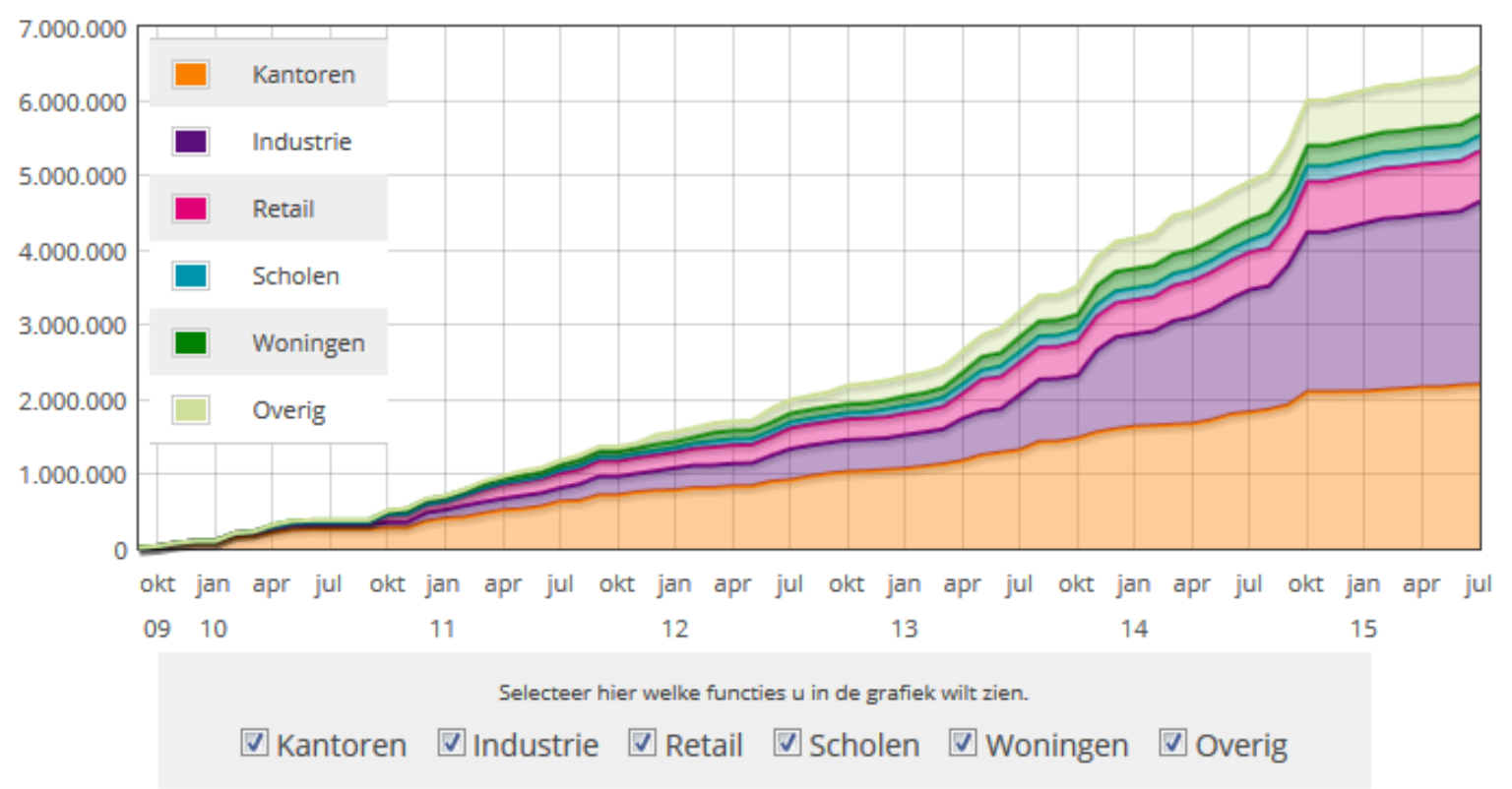

Het weergegeven aantal $\mathrm{m}^{2}$ betreft unieke registraties. Geannuleerde projecten, dubieuze registraties en mogelijke dubbelingen vanwege ontwerpregistratie en opleverregistratie zijn hier uitgefilterd.

Figuur 4.6 Unieke registraties BREEAM-NL Nieuwbouw in $\mathrm{m}^{2}$ Bron: BREEAM (2015).

Figuur 4.7 laat tot slot het aantal $\mathrm{m}^{2}$ BVO zien waarvoor een bouwvergunning is verleend (cijfers CBS), uitgezet tegen het aantal $\mathrm{m}^{2}$ BVO dat bij de DGBC is geregistreerd voor certificering. Van de cijfers van het CBS zijn enkel de Combinatie bedrijfshallen, Kantoren en Winkels meegenomen in het overzicht en uitgezet tegen de registraties bij de DGBC van hetzelfde type. Wat opvalt is dat het aantal registraties bij de DGBC de laatste jaren enorm is toegenomen. In recente jaren lag het aantal registraties zelfs hoger dan het aantal projecten dat een bouwvergunning heeft gekregen. Dat is echter eenvoudig te verklaren: het moment van bouwvergunningaanvraag en registratie voor BREEAM-NL-certificering is niet hetzelfde. In de regel zal later besloten worden tot BREEAM-NLcertificering over te gaan. Hierdoor zijn er projecten die in 2008 of 2009 een bouwvergunning hebben gekregen en in 2013 pas registreren voor een BREEAM-NL-certificering (zie BREEAM, 2015).

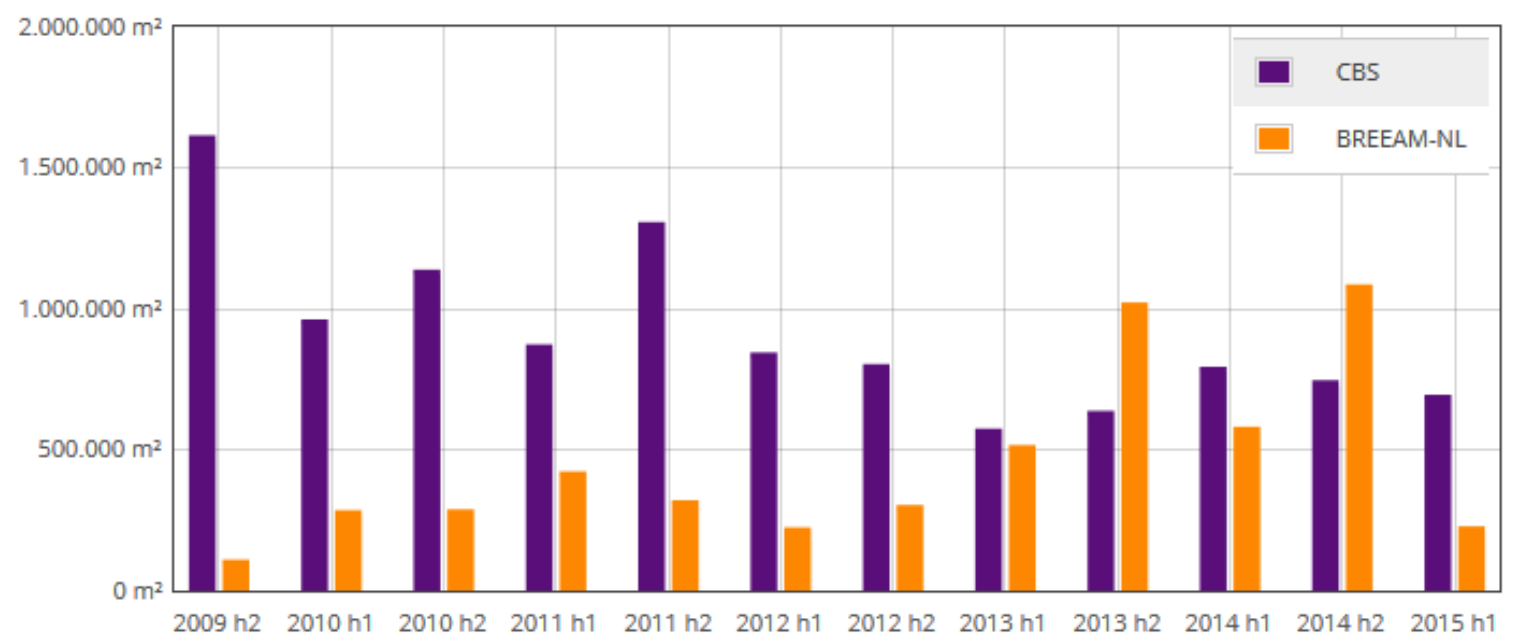

Figuur 4.7 Aantal $\mathrm{m}^{2}$ bouwvergunning vergeven (CBS) uitgezet tegen registratie BREEAM-NL Nieuwbouw Bron: BREEAM (2015). 


\subsubsection{Conclusie}

Enkele criteria binnen het keurmerk BREEAM-NL Nieuwbouw en Renovatie s zijn gericht op landgebruik en ecologie en dragen zodoende mogelijk bij aan het integreren van natuur en biodiversiteit in de bedrijfsvoering. Het keurmerk is echter voornamelijk gericht op het verbeteren van de milieucondities. Het effect van maatregelen op natuur en biodiversiteit wordt niet gemeten. $\mathrm{Er}$ wordt wel gemeten in welke mate de maatregelen voldoen aan de criteria-eisen, maar dat gaat om een inspanningsverplichting, niet om een resultaatverplichting ten aanzien van natuur en biodiversiteit.

\subsection{Synthese}

- De criteria van keurmerken met natuur- en biodiversiteitselementen zijn bewust breed zodat bedrijven zelf kunnen bepalen welke maatregelen passend zijn bij hun bedrijf om te voldoen aan de criteria van het keurmerk. Tegelijk maakt dit het lastig om criteria te beoordelen zonder inzicht te hebben in de maatregelen die bedrijven werkelijk genomen hebben, hoe lang ze deze maatregelen volhouden en of ze maatregelen evalueren en/of bijstellen.

- Een deel van de bedrijven in een sector is aangesloten bij een keurmerk. Daaruit concluderen we dat het niet voor alle bedrijven aantrekkelijk is om deel te nemen, waarschijnlijk omdat het economisch rendement van de benodigde maatregelen voor hen niet positief is.

- Maatregelen op het gebied van natuur, landschap en biodiversiteit dragen het vaakst duidelijk bij aan herstel van soorten of leefgebied. De positieve impact van maatregelen op het gebied van energie, water, materialen, emissies en producten/diensten dragen wellicht bij aan herstel van kwaliteit van leefgebied, maar dit effect is erg onzeker.

- Afzonderlijke maatregelen zoals het creëren van nestgelegenheid leveren meerwaarde op als ook voldaan wordt aan het creëren van voedselaanbod en/of winterhabitat, bijvoorbeeld door de aanleg van kleine landschapselementen binnen of buiten het bedrijf. Een betere samenhang van maatregelen onderling en overleg met andere bedrijven en natuur/landschapsorganisaties buiten het bedrijf zou de effectiviteit van maatregelen sterk verbeteren.

- Keurmerken verwijzen vaak naar andere keurmerken in hun criteria. In deze studie zijn deze keurmerken niet bij de beoordeling betrokken, maar waarschijnlijk gaat het hier voornamelijk om milieu keurmerken die niet (direct) gericht zijn op het vergroten van de biodiversiteit.

- Criteria voor biodiversiteit in het keurmerk van Green Key en BREEAM leiden relatief tot weinig extra punten, terwijl een ambitieuze uitvoering ervan namelijk een bedrijfsnatuurplan maken, uitvoeren en monitoren met een deskundige/ecoloog een behoorlijke inspanning is. Voor alle keurmerken zou het goed zijn als een ambitieuzer natuurplan ook tot extra bonuspunten zou leiden.

- Begrippen als duurzaamheid en biodiversiteit worden veel gebruikt, maar zijn zelden strak gedefinieerd. Volgens SMK is er behoefte aan een gedeeld begrippenkader, een geharmoniseerde maatlat voor natuurlijk kapitaal en biodiversiteit. Op dit moment maakt elke organisatie nog zijn eigen schema, waardoor er geen breed gedragen, praktisch concept van de werkelijkheid bestaat. Daarbij is de kans groot dat veel langs elkaar heen wordt gepraat. 
Groene Cirkels is een samenwerking tussen Heineken Nederland BV, Alterra Wageningen UR en de Provincie Zuid-Holland. Zij willen met duurzame ontwikkeling een voorbeeld van wereldklasse realiseren voor de maatschappij van de toekomst. Eind 2015 werd besloten de samenwerking te verlengen met als ambitie: - een $\mathrm{CO}_{2}$-neutrale brouwerij in een $\mathrm{CO}_{2}$-neutrale keten, - een duurzame economie in een aangename leefomgeving, waarin de natuur aan deze ambitie bijdraagt, en - kennis ontwikkeling voor een duurzame maatschappij.

De aanpak van Groene Cirkels is gebaseerd op: Het realiseren van een brede samenwerking op basis van een gedeeld beeld van onze toekomst. Samen met burgers en bedrijven wil het partnership komen tot een duurzaam en toekomstbestendig Zuid-Holland. De kennis en ervaring die hieruit voorkomt, wil het partnership delen met andere partijen om een transitie naar een toekomstbestendige economie te versnellen. De natuur is onze partner. De partners willen de kracht van de natuur benutten; de natuur en natuurlijke processen zijn dan ook de inspiratie. Thema's. Groene Cirkels zoekt naar verbinding met andere partijen en organiseert zogenoemde Groene Cirkel-netwerken op 5 thema's:

a. Stimuleren van duurzame energie en reductie van broeikasemissies

b. Verzekeren van voldoende en goed water

c. Sluiten van grondstof kringlopen

d. Verduurzamen mobiliteit en logistiek en

e. Verbeteren van de leefomgeving en versterken van biodiversiteit.

Het project resultaatmeting heeft als doel op systematische wijze gegevens te verzamelen om inzicht te krijgen in hoe de netwerken zich ontwikkelen en de voortgang en impact te monitoren. Het verzamelen van de gegevens vraagt specificatie van maatstaven die een goede indicator zijn voor het te monitoren proces of resultaat. Dit blijkt geen eenvoudige zaak:

a. omdat er op meerdere schaalniveaus wordt gewerkt;

b. om passende indicatoren te benoemen; en

c. omdat de benodigde gegevens (nog) niet (altijd) beschikbaar zijn.

De eerste resultaatmeting is eind 2015 uitgevoerd, zie hieronder de concept visualisatie van het Groene Cirkel-netwerk Leefomgeving. Daarnaast wordt op projectniveau gemonitord, bijvoorbeeld bestuivende insecten in de regio Wijk\&Wouden (Bijen en zweefvliegen in het Land van Wijk en Wouden: nulmeting 2015, Menno Reemer, 2015).

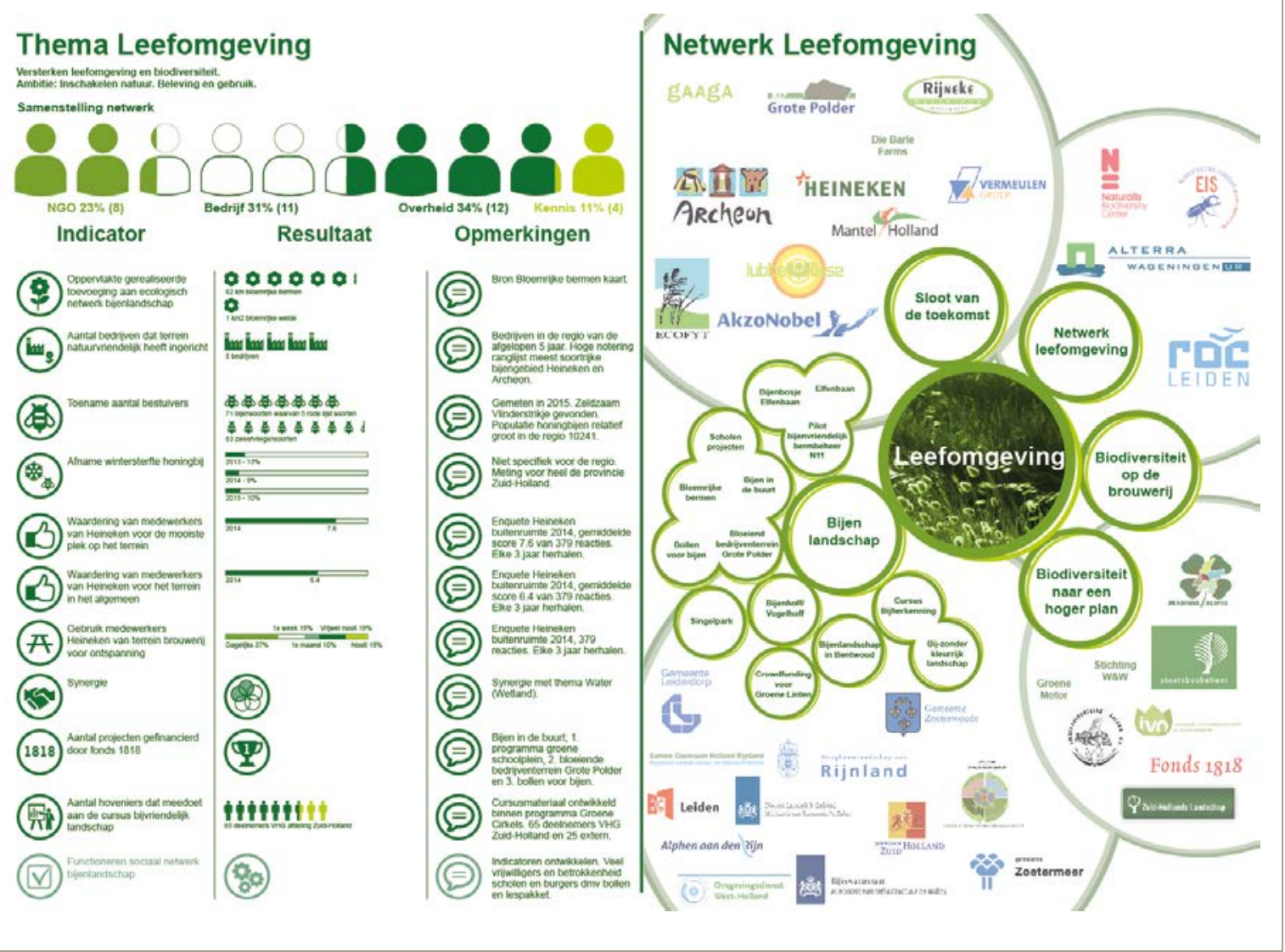




\section{Conclusies en aanbevelingen}

\section{$5.1 \quad$ Conclusies}

De overheid zet in op natuurinclusieve economie (zie Rijksnatuurvisie; EZ, 2014). Om het effect van dit beleid op natuur te bepalen, is inzicht nodig in hoe natuurinclusieve economie doorwerkt op natuur. Met dit inzicht worden indicatoren geselecteerd, die met meetgegevens worden gekwantificeerd.

Natuurinclusieve economie kan op bedrijfsniveau worden gemeten en geaggregeerd naar hoger, voor natuur relevant, schaalniveau. Om de effecten op natuur in Nederland te kunnen meten zijn zowel het bedrijf als het omringende landschap (waarop de aantalsontwikkelingen van soorten kunnen worden gemonitord) relevante schaalniveaus.

Relevante begrippen natuurinclusieve economie

- Veel begrippen die worden gebruikt bij natuurinclusieve economie kennen verschillende definities; onder andere: natuur, biodiversiteit, ecosysteemdiensten. Helderheid over de gebruikte definitie is noodzakelijk als partijen samenwerken.

- De in (wetenschappelijke) literatuur gebruikte terminologie, zoals ecosysteemdiensten en natuurlijk kapitaal, is voor managers uit het mkb te abstract. Een begrip als natuur of biodiversiteit wordt wel herkend.

- Een keurmerk (gekoppeld aan natuurinclusieve economie) is een extra attribuut van een eindproduct waardoor het voor de consument onderscheidend is in het winkelschap, en de consument deze bijdrage aan natuurinclusieve economie expliciet (met geld) kan waarderen.

Methode om meetbaar te maken

- Om effecten van voorgenomen beleid meetbaar te maken, is een door de stakeholders gedragen raamwerk nodig (de beleidstheorie). Een eenvoudige versie van het raamwerk is gemakkelijk te communiceren, een meer gedetailleerde versie geeft de indicatoren weer die worden gemeten.

- Het in dit rapport beschreven raamwerk is doorgesproken met keurmerkhouders en bedrijven. Voor toepassing in de praktijk, moet het zoveel mogelijk sectorspecifiek worden ingevuld. Dan is het goed herkenbaar voor de betrokken bedrijven.

- Er wordt al door overheid, ngo's en het bedrijfsleven gemeten en gerapporteerd over deelrelaties tussen natuur en economie. Zo rapporteren met name grote bedrijven over hun duurzaamheidsprestaties en wordt het voorkomen van veel plant- en diersoorten geteld. De metingen van bedrijven en van ecologen zijn niet aan elkaar te koppelen, waardoor het nu niet mogelijk is om het effect van natuurinclusieve economie op natuur te bepalen.

- Duurzaamheidsrapportages van bedrijven kennen hun eigen schaalniveau. Grote ondernemingen met een GRI 4 duurzaamheidsrapportage rapporteren op de schaal van hun hele onderneming (wereldschaal) en niet separaat voor de vestigingen. Hierdoor is de directe relatie tussen hun natuurinclusief ondernemen en natuur niet te leggen.

- Het effect van activiteiten op natuur en milieu in duurzaamheidsrapportages wordt in veel gevallen bepaald aan de hand van indicatoren die het bedrijf al voorhanden heeft. $\mathrm{CO}_{2}$-emissie en watergebruik zijn veel gemakkelijker te meten dan de directe prestatie van een bedrijf op gebied van natuur, omdat natuurkwaliteit en de bijdrage van een bedrijf eraan locatiespecifiek is.

Gebruik door EZ in het beleid

- Bedrijven die deelnemen aan keurmerken, die 'natuurinclusieve economie' criteria hanteren, kunnen als voorbeeld dienen voor andere bedrijven in de sector. Een dergelijk keurmerk legt ook de natuurinclusieve inspanning van het bedrijf vast (als het criterium kwantitatief is ingevuld) en houdt het aantal bedrijven bij dat meedoet. De criteria van deze keurmerken en de bijbehorende maatregelen van bedrijven kunnen aanknopingspunten bieden voor EZ-beleid.

- Bedrijven nemen vrijwillig deel aan een keurmerk, de voordelen wegen voor hen op tegen de nadelen. Het zijn waarschijnlijk de voorlopers die zich aansluiten bij het keurmerk (er is sprake van 
zelfselectie). We veronderstellen daarom dat de bij een keurmerk aangesloten bedrijven, niet overeenkomen met het gemiddelde bedrijf. De natuurresultaten van keurmerkbedrijven kunnen daarom niet zo maar worden opgeschaald. Maar het is wel mogelijk om de natuurpotentie te berekenen bij groeiende deelname (zie aanbevelingen).

- Keurmerkhouders registreren de maatregelen die bedrijven nemen. De effecten van deze maatregelen worden niet gemeten. Effectbepaling op natuur vinden bedrijven te veel werk/rompslomp. Er bestaat daardoor geen zicht op de effectiviteit van de maatregelen en het is lastig om een verband te leggen tussen een keurmerk en de bijdrage aan natuur. Door aanpassingen in het keurmerk zou dit in toenemende mate wel mogelijk zijn (zie aanbevelingen).

\subsection{Aanbevelingen}

Aanbevelingen voor het ministerie van EZ

- Er wordt al informatie vastgelegd over de relatie tussen natuur en economie, een nieuw meet- en rapportagesysteem is niet aan de orde. Aansluiten op bestaande meetsystemen heeft ook als voordeel dat ontwikkelingen in de tijd (eerder) gemeten kan worden.

- Samenwerking tussen EZ, bedrijven, onderzoeksinstellingen en natuurorganisaties is belangrijk voor (het meetbaar maken van) natuurinclusieve economie. Deze partijen kunnen het gepresenteerde raamwerk op maat maken en consequent gebruiken; hierdoor wordt het begrip natuurinclusieve economie voor iedereen helder. Via 'business model workshops' op basis van dit raamwerk kunnen deze partijen een gezamenlijk natuurinclusief plan ontwikkelen.

- Als het natuurinclusieve raamwerk helder is voor de stakeholders, wordt het effect van bedrijfskeuzes op biodiversiteit en ecosysteemdiensten duidelijker en kunnen bedrijven beter onderbouwde keuzes maken. Hiervoor hoeven niet per se de relaties gekwantificeerd te zijn. Relaties (pijlen) in het raamwerk waarvan nu onvoldoende bekend is, kunnen met onderzoek worden ingevuld. Door het gepresenteerde raamwerk per sector te concretiseren, kan informatie eenvoudiger worden gedeeld tussen verschillende partijen. EZ kan hierbij faciliteren.

- Maak onderscheid in analyses en overheidsbeleid naar type bedrijf (zoals in dit rapport), omdat de impact op natuur erg verschilt tussen sectoren. Om natuurinclusieve economie meetbaar te maken, is het zinvol om per sector afspraken te maken over het raamwerk, om het zoveel mogelijk te laten aansluiten bij de belevingswereld van de sector.

- Om natuureffecten op landschapsniveau te bereiken, is regionale samenwerking van partijen belangrijk. We stellen voor om samen met een keurmerk een methode te ontwikkelen en te toetsen om het (potentiele) regionale effect van het keurmerk op de natuur te bepalen.

- We adviseren om samen met een keurmerk en onderzoeksinstituut vast te stellen wat de potentiële natuurwinst is als de gehele sector volgens de criteria van het keurmerk zou werken.

- In dit project hebben we gefocust op de directe effecten van natuurinclusieve economie op natuur. In een vervolgstudie kunnen ook de keten (zie van Oorschot et al., 2013) en de indirecte effecten worden meegenomen.

- Keurmerken richten zich op de voorlopers. Voor het bereiken van een natuurinclusieve economie moeten ook de andere bedrijven worden gestimuleerd om aan criteria te voldoen. Het advies aan EZ is om daar ook beleid op te richten. Dit zou kunnen betekenen dat naast stimulerende instrumenten voor de koplopers ook instrumenten voor de volgers nodig kan zijn.

Aanbevelingen voor keurmerken

- Meet de natuur- en biodiversiteitsbijdrage van een bedrijf op hetzelfde schaalniveau als de natuurinclusieve activiteiten. Als een akkerrand wordt aangelegd, meet dan het effect op het voorkomen van lokale soorten als insecten en niet op soorten met een grotere oppervlakte behoefte.

- Het meten van de effecten op de biodiversiteit (het gaat hier om tellingen van soorten), kan in samenwerking met natuurverenigingen worden uitgevoerd. Aan deze verenigingen zijn vrijwilligers verbonden die tellingen (kunnen) uitvoeren.

- Beloon (extra) in de keurmerken maatregelen die in samenwerking met andere bedrijven (of natuurgebieden) in de omgeving worden genomen, omdat deze meer natuurwaarde opleveren. 


\section{Literatuur en websites}

ACCA, Flora \& Fauna International, en KPMG. 2014. Business and investors: providers and users of natural capital disclosure.

https: //www. kpmg.com/UK/en/I ssuesAndl nsights/ArticlesPublications/Documents/PDF/Audit/ natur al-capital-reporting. pdf

Alkemade, R., van Oorschot, M., Miles, L., Nellemann, C., Bakkenes, M., en Ten Brink, B. 2009. GLOBIO3: a framework to investigate options for reducing global terrestrial biodiversity loss. Ecosystems, 12(3), 374-390.

ANK. 2016. http://www. atlasnatuurlijkkapitaal.nl/home

Bishop, J., S. Kapila, F. Hicks, P. Mitchell en F. Vorhies. 2009. New Business Models for Biodiversity Conservation, J ournal of Sustainable Forestry 28: 285-303.

de Blaeij, A. T., N. Polman, en S. Reinhard. 2011. Economic governance to expand commercial wetlands: within- and cross-scale challenges. Ecology and Society 16(1): 33. [online] URL: http://www. ecologyandsociety.org/vol16/iss1/art33/

Bouma, J. en C. Leenders. 2013. Bedrijven \& Biodiversiteit - Verkenning van een beleidsinstrumentarium. Tijdschrift Milieu - Dossier - december 2013 pp36-39

BREEAM. 2015. https://www. breeam.nl, geraadpleegd op 19 december 2015

Brink, B.J.E. ten. 2000. Biodiversity indicators for the OECD Environmental Outlook and Strategy. RIVM.

CLO. 2015. Compendium voor de Leefomgeving.

http:// www. compendiumvoordeleefomgeving. nl/indicatoren/nl0165-Broeikasgasemissies-inNederland. html? i=5-20

COM. 2006. Handbook on Common Monitoring and Evaluation Framework. Guidance Document. Rural development 2007-2013. Directorate General for Agri-culture and Rural Development, September, http://ec. europa. eu/agriculture/rurdev/eval/guidance/document en. pdf.

Daily, G. C., S., Polasky, J. Goldstein, P.M. Kareiva, H.A. Mooney, L. Pejchar, T. H. Ricketts, J. Salzman en R. Shallenberger. 2009. Frontiers in Ecology and the Environment, Vol. 7, No. 1, pp. $21-28$

EZ. 2014. Rijksnatuurvisie 2014 Natuurlijk verder. Den Haag. Ministerie van Economische Zaken. FEE. 2015. FEE J aarverslag 2014. Utrecht. Foundation for Environmental Education (FEE) Nederland.

Fontein, R.J., R. Michels, V. Linderhof, M. Goossen en R. de Graaff. 2015. De potentie van natuurcombinaties; Inzicht en reflecties op de meerwaarde van een nieuw concept. Alterra-rapport 2648, Wageningen, Alterra Wageningen UR, 56 blz.

Gaaff, A. en S. Reinhard. 2012. Incorporating the value of ecological networks into cost-benefit analysis to improve spatially explicit land-use planning. Ecological economics 73: 66-74.

GRI. 2016. www. globalreporting.org/standards/Pages/default. aspx

Groot, R. S. de, R. Alkemade, L. Braat, L. Hein, en L. Willemen. 2010. Challenges in integrating the concept of ecosystem services and values in landscape planning, management and decision making. Ecological complexity 7. 260-272.

Haines-Yong, R. en M. Potschin. 2013. CICES V4.3 - Revised report prepared following consultation on CICES Version 4, August-December 2012. EEA Framework Contract No EEA/IEA/09/003

Hanson, C., J. Ranganathan, C. I celand, en J. Finisdore. 2008. The Corporate Ecosystem Services Review: Guidelines for Identifying Business Risks \& Opportunities Arising from Ecosystem Change, World Resources Institute: Washington DC

Houdet, J., M. Trommetter, en J. Weber. 2012. Understanding changes in business strategies regarding biodiversity and ecosystem services. Ecological Economics 73: 37-46

Knegt, B. de (ed.). 2014. Graadmeter Diensten van Natuur; Vraag, aanbod, gebruik en trend van goederen en diensten uit ecosystemen in Nederland. Wettelijke Onderzoekstaken Natuur \& Milieu, WOt-technical report 13.

KPMG. 2012. TEEB voor het Nederlandse bedrijfsleven The Economics of Ecosystems \& Biodiversity. kpmg.nl 
Maes J., A. Teller, M. Erhard, C. Liquete, L. Braat, P. Berry, B. Egoh, P. Puydarrieux, C. Fiorina, F. Santos, M.L. Paracchini, H. Keune, H. Wittmer, J. Hauck, I. Fiala, P.H. Verburg, S. Condé, J.P. Schägner, J. San Miguel, C. Estreguil, O. Ostermann, J.I. Barredo, M.H. Pereira, A. Stott, V. Laporte, A. Meiner, B. Olah, E. Royo Gelabert, R. Spyropoulou, J.E. Petersen, C. Maguire, N. Zal, E. Achilleos, A. Rubin, L. Ledoux, C. Brown, C. Raes, S. Jacobs, M. Vandewalle, D. Connor, en G. Bidoglio. 2013. Mapping and Assessment of Ecosystems and their Services. An analytical framework for ecosystem assessments under action 5 of the EU biodiversity strategy to 2020 . Publications office of the European Union, Luxembourg.

NCC (Natural Capital Coalition). 2015. Natural Capital Protocol. Draft for consultation. November 2015.

Oorschot, M. van, M. Kok, J. Brons, S. van der Esch, J. Janse, T. Rood, E. Vixseboxse, H. Wilting en W. Vermeulen. 2013. Verduurzaming van internationale handelsketens. Den Haag. PBL Planbureau voor de Leefomgeving PBL-publicatienummer: 630

OpenNess (Operationalisation of Natural Capital and Ecosystem Services). 2014. Benefiting from ecosystem services: towards a shared understanding. OpenNESS brief, no. 01, January 2014. http://www.openness-project. eu/sites/default/files/OpenNESS_brief_01.pdf (bezocht op 2 februari 2016)

PBL. 2016 http://themasites. pbl.nl/natuurlijk-kapitaal-nederland/

Ravon. 2016. (Reptielen Amfibieën Vissen Onderzoek Nederland) http://www.ravon. nl/RAVONActief/Veldonderzoek(NEM)/tabid/1175/Default.aspx (bezocht op 12 januari 2016)

Sijtsma, F.J., A. van Hinsberg, S. Kruitwagen, en F.J. Dietz. 2009. Natuureffecten in de MKBA's van projecten voor integrale gebiedsontwikkeling. Bilthoven. PBL-publicatienummer 500141004

Spurgeon, J. 2014. Business @ Biodiversity Workstream 1: Natural Capital Accounting for Business: Guide to selecting an approach.

TEEB. 2010. TEEB - The Economics of Ecosystems and Biodiversity for Local and Regional Policy Makers.

Troy, A., en M. A. Wilson. 2006. Mapping ecosystem services: practical challenges and opportunities in linking GIS and value transfer. Ecological economics 60.2 (): 435-449.

Verdouw, C.N., N. Bondt, H. Schmeitz, en H. Zwinkels.2014. Towards a Smarter Greenport: PublicPrivate Partnership to Boost Digital Standardisation and Innovation in the Dutch Horticulture. International Journal on Food System Dynamics 5 (1). - p. 44 - 52

Vos, C.C., C.J Grashof-Bokdam, and P.F.M. Opdam. 2014 Biodiversity and ecosystem services: does species diversity enhance effectiveness and reliability? WOt-technical report 25.

van Vuuren, D.P., M. Kok, S. Esch, M. Jeuken, P. Lucas, A.G. Prins, ... en Hilderink, H. 2012. Roads from Rio+ 20. Pathways towards global sustainable development targets for 2050 .

WBCSD (World Business Council for Sustainable Development). 2011. Guide to Corporate Ecosystem Valuation A framework for improving corporate decision-making.

Wormgoor, W.D. 2013. BREEAM-NL in een notendop, Bouwwereld, \#6 2013, 34-35, zie: http: // www. peutz.nl/sites/default/files/publicaties/BWE_07-2013_LR-PDF\%2034-35_0.pdf 


\section{Bijlage 1 Ecosysteemdiensten Atlas Natuurlijk Kapitaal}

Tabel A1 De uitgewerkte thema's en indicatoren uit de Atlas Natuurlijk Kapitaal Bron: Atlas natuurlijk Kapitaal (2016).

\begin{tabular}{|c|c|c|}
\hline Thema & Onderwerp & Graadmeter \\
\hline Bestuiving & Bestuiving & Potentieel aanbod natuurlijke bestuiving \\
\hline \multirow[t]{2}{*}{ Biomassa voor energie } & & Potentieel biogas uit vloeibare mest in GJ/(ha/jaar) \\
\hline & & Potentieel biogas uit GFT in GJ/(ha/jaar) \\
\hline \multirow[t]{2}{*}{ Bodem } & \multirow[t]{2}{*}{ Bodemverontreiniging } & Vorderingen Bodemonderzoek en sanering \\
\hline & & $\begin{array}{l}\text { Locaties met mogelijke Bodemverontreiniging (HBB } \\
\text { locaties) }\end{array}$ \\
\hline \multirow[t]{2}{*}{ Bodemerosie } & \multirow[t]{2}{*}{ Bodemerosie } & Gevoeligheid en bescherming tegen winderosie \\
\hline & & Gevoeligheid en bescherming tegen watererosie \\
\hline \multirow[t]{4}{*}{ Bodemvruchtbaarheid } & \multirow[t]{4}{*}{ Bodemvruchtbaarheid } & Bodemvruchtbaarheid voor landbouw \\
\hline & & $\begin{array}{l}\text { Koolstofcyclus en -dynamiek in de bovenste } \\
\text { bodemlaag (relatief) }\end{array}$ \\
\hline & & $\begin{array}{l}\text { Robuustheid en herstelvermogen van de bodem } \\
\text { (relatief) }\end{array}$ \\
\hline & & $\begin{array}{l}\text { Bijdragen van de bodem aan klimaatregulatie } \\
\text { (relatief) }\end{array}$ \\
\hline \multirow[t]{6}{*}{ Cultureel Erfgoed } & \multirow[t]{4}{*}{ Monumenten } & Buitenplaatsen \\
\hline & & Archeologische Monumenten Kaart (AMK) \\
\hline & & Indicatieve Kaart Archeologische Waarden \\
\hline & & Rijksmonumenten \\
\hline & Erfgoed & Stads- en Dorpsgezichten \\
\hline & & Werelderfgoed \\
\hline \multirow[t]{8}{*}{ Drinkwater } & \multirow[t]{8}{*}{ Drinkwater } & $\begin{array}{l}\text { Verandering nitraatconcentratie in het grondwater bij } \\
\text { natuurgebieden }\end{array}$ \\
\hline & & Verzilting grondwater \\
\hline & & $\begin{array}{l}\text { Locaties drinkwateronttrekkingen uit } \\
\text { oppervlaktewater }\end{array}$ \\
\hline & & Drinkwaterwinningen uit grondwater \\
\hline & & Kwaliteit van drinkwater in Nederland (2012) \\
\hline & & Verzilting oppervlaktewater \\
\hline & & Grondwaterbeschermingsgebieden \\
\hline & & $\begin{array}{l}\text { Verandering nitraatconcentratie in het grondwater (5- } \\
15 \mathrm{~m} \text { diep) }\end{array}$ \\
\hline \multirow[t]{3}{*}{ Geluid } & wegverkeer & Alle wegen 2011 (Lden) \\
\hline & Geluid vliegverkeer & Schiphol Geluid 2011 \\
\hline & Spoorwegen & Geluid treinverkeer over een etmaal \\
\hline \multirow[t]{7}{*}{ Groen } & \multirow[t]{5}{*}{ Beschikbaarheid } & Natura 2000-gebieden (peildatum 17 februari 2015) \\
\hline & & Natuurnetwerk Nederland (EHS) \\
\hline & & Nationale Parken \\
\hline & & Groen Beschikbaarheid Openbaar Groen bij Woningen \\
\hline & & PBL \\
\hline & \multirow[t]{2}{*}{ Gebruik } & Fietsknooppunten netwerk \\
\hline & & Groen Gebruik Speelruimte 2008 RIVM \\
\hline \multirow[t]{5}{*}{ Groene recreatie } & \multirow[t]{5}{*}{ Groene recreatie } & Belevingswaarde van het landschap \\
\hline & & Recreatieaanbod voor fietsen in een groene omgeving \\
\hline & & $\begin{array}{l}\text { Recreatieaanbod voor wandelen in een natuurlijke } \\
\text { setting }\end{array}$ \\
\hline & & Beschermde natuurmonumenten buiten Natura2000 \\
\hline & & Zwemwater locaties en kwaliteit \\
\hline \multirow[t]{2}{*}{ Hernieuwbare energiebronnen } & \multirow[t]{2}{*}{ Hernieuwbare energiebronnen } & Aardwarmtepotentiekaarten van Nederland (uit DINO) \\
\hline & & Windkaart (m/s) \\
\hline
\end{tabular}


Thema Onderwerp

Hout Vezels Genetische bronnen Hout
Graadmeter

Staande houtvoorraad van het Nederlandse bos

Gemiddelde staande houtvoorraad van het

Nederlandse bos

Potentiële houtoogst van stamhout van het

Nederlandse bos

Potentiële oogst van tak- en tophout van het

Nederlandse bos

Potentiële houtoogst van stamhout buiten het bos

Potentiële oogst van tak- en tophout buiten het bos

Vezels

Biomassa - bermmaaisel

Biomassa natuurgebied - grasmaaisel

Biomassa natuurgebied - riet en heide

Biomassa landbouwgebied - stro

Biomassa landbouwgebied - stengel en bladresten

Biomassa - vaste mest

Biomassa - dunne mest

Genetische bronnen

Wingebieden schelpen

Koolstofvastlegging

koolstofvastlegging
Bodemkoolstofvoorraad

Bodemkoolstofvoorraad in natuurgebieden (ton $\mathrm{C} / \mathrm{ha}$ )

Bodemkoolstof balans in landbouwgronden

Bovengrondse koolstofvoorraad in natuurgebieden

Koolstofvastlegging in de bodem: totaal van alle

maatregelen

Koolstofvastlegging in de bodem bij

akkerrandenbeheer

Koolstofvastlegging in de bodem zonder

grondbewerking

Koolstofvastlegging in de bodem bij achterlaten

gewasresten

Koolstofvastlegging in de bodem bij niet scheuren

grasland

Koolstofvastlegging in de bodem bij niet kerende

grondbewerking

Koolstofvastlegging in de bodem bij groenbemesting

Koolstofvastlegging in de bodem bij verbeteren

gewasrotatie

Bescherming tegen overstroming

Soortendiversiteit in Nederland

Soortendiversiteit van Rode-Lijstsoorten

Genetische structuur van de Hamsterpopulatie

(Cricetus cricetus)

Genetische structuur van de Boommarter populatie

(Martes martes)

Genetische structuur Nederlandse Otterpopulatie

(Lutra lutra)

Klein zeegras (Zostera noltii) 2011

Groot zeegras (Zostera marina) in 2011

Snavelruppia (Ruppia maritima) 2011

Wetlandgebieden 2005 (RAMSAR)

Beschermde natuurgebieden - habitatbescherming

Bronpopulaties voor zaadproductie van bomen \&

struiken

Ecologisch kapitaal bodem, door diffuse

bodemverontreiniging aangetast

Natuurwaarde van natte en vochtige ecosystemen

Conservation Units voor bomen 


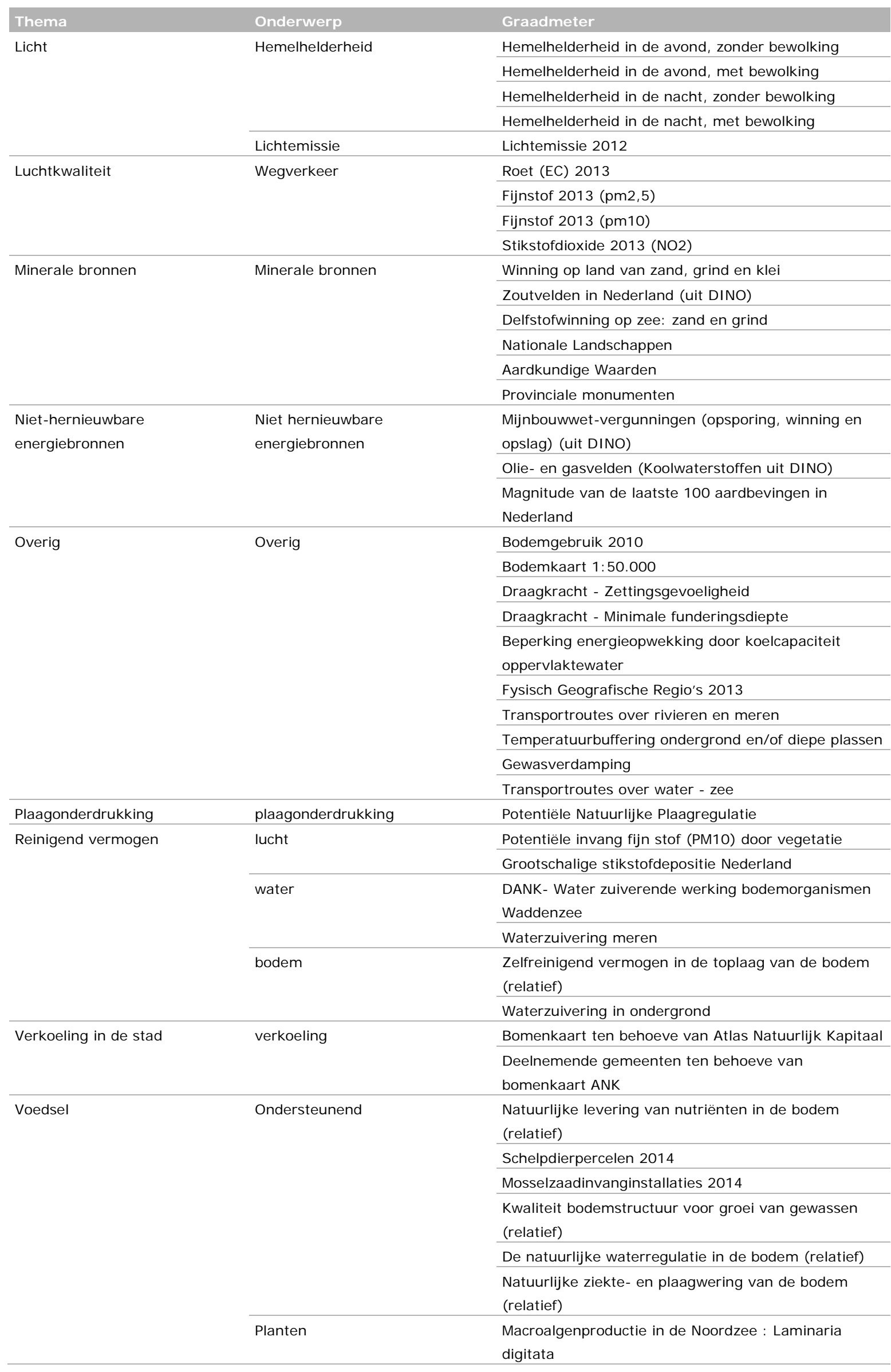




\begin{tabular}{|c|c|c|}
\hline Thema & Onderwerp & Graadmeter \\
\hline Water & Waterrecreatie & Zwemwaterlocaties \\
\hline \multirow[t]{12}{*}{ Water overig } & \multirow[t]{12}{*}{ Water overig } & $\begin{array}{l}\text { Locaties industriewateronttrekkingen uit } \\
\text { oppervlaktewater }\end{array}$ \\
\hline & & $\begin{array}{l}\text { Beregeningsonttrekkingen: locaties onttrekkingen uit } \\
\text { grondwater en oppervlaktewater }\end{array}$ \\
\hline & & Verdeelpunten hoofdwatersysteem (kranen) \\
\hline & & $\begin{array}{l}\text { Beregening: vermeden reductie van } \\
\text { gewasverdamping }\end{array}$ \\
\hline & & Tekort zoetwater voor peilbeheer in gemiddeld jaar \\
\hline & & Beregeningsonttrekkingen: effect op grondwaterkwel \\
\hline & & $\begin{array}{l}\text { Tekort zoet oppervlaktewater voor de landbouw - } \\
\text { extreem droog jaar }\end{array}$ \\
\hline & & Tekort zoetwater voor doorspoeling in gemiddeld jaar \\
\hline & & $\begin{array}{l}\text { Tekort zoet oppervlaktewater voor de landbouw - } \\
\text { droog jaar }\end{array}$ \\
\hline & & Gemiddelde afvoer van de Rijn en Maas \\
\hline & & $\begin{array}{l}\text { Tekort zoet oppervlaktewater voor de landbouw - } \\
\text { gemiddeld jaar }\end{array}$ \\
\hline & & Tekort zoetwater voor beregening in gemiddeld jaar \\
\hline \multirow[t]{7}{*}{ Waterberging } & \multirow[t]{7}{*}{ waterberging } & Vocht leverend vermogen door de bodem \\
\hline & & $\begin{array}{l}\text { Waterbergend vermogen van de grote } \\
\text { oppervlaktewateren }\end{array}$ \\
\hline & & Waterbergend vermogen van regionale wateren \\
\hline & & Waterbergend vermogen van Rijntakken \\
\hline & & Waterbergend vermogen Maas \\
\hline & & Waterbergend vermogen van de ondergrond \\
\hline & & Waterregulering ondergrond \\
\hline \multirow[t]{2}{*}{ Wetenschap en educatie } & \multirow[t]{2}{*}{ Wetenschap en educatie } & $\begin{array}{l}\text { Ecologisch kapitaal van de onafgedekte, intacte } \\
\text { bodem }\end{array}$ \\
\hline & & Habitatfunctie en biodiversiteit \\
\hline
\end{tabular}




\section{Bijlage 2 Graadmeters ecosysteemdiensten uit de Knegt et al. (2014)}

Tabel A.2 Overzicht van graadmeters om beschikbaarheid van ecosysteemdiensten te meten. Uit: de Knegt et al. (2014)

\begin{tabular}{|c|c|c|}
\hline Ecosysteemdienst & Levering dienst & Graadmeter(s) \\
\hline Voedsel & $\begin{array}{l}\text { Levering uit ecosystemen in NL tov de huidige vraag }=70 \% \text {, levering uit } \\
\text { ecosystemen buitenland tov de huidige vraag }=30 \% . \text { Relatieve bijdrage } \\
\text { van ecosystemen: natuurgebied } 1 \% \text {, agrarisch gebied } 98 \% \text {, urbaan } \\
\text { gebied } 1 \%\end{array}$ & $\begin{array}{l}\text { Areaal gewassen } \\
\text { Voedsel productie } \\
\text { index } \\
\text { Foodprint per capita }\end{array}$ \\
\hline Drinkwater & $\begin{array}{l}\text { Levering uit ecosystemen in NL tov de huidige vraag }=49 \% \text {, levering uit } \\
\text { ecosystemen buitenland tov de huidige vraag }=0 \% \text {. Relatieve bijdrage } \\
\text { van ecosystemen: natuurgebied } 100 \% \text {, agrarisch gebied } 0 \% \text {, urbaan } \\
\text { gebied } 0 \%\end{array}$ & $\begin{array}{l}\text { Productie drinkwater } \\
\text { naar bron } \\
\text { (Drinkwaterbalans) } \\
\text { Waterwinning en } \\
\text { watergebruik } \\
\text { Ruimtegebruik } \\
\text { openbare } \\
\text { watervoorziening }\end{array}$ \\
\hline Hout & $\begin{array}{l}\text { Levering uit ecosystemen in NL tov de huidige vraag }=8 \% \text {, levering uit } \\
\text { ecosystemen buitenland tov de huidige vraag }=92 \% \text {. Relatieve bijdrage } \\
\text { van ecosystemen: natuurgebied } 100 \% \text {, agrarisch gebied } 0 \% \text {, urbaan } \\
\text { gebied } 0 \%\end{array}$ & $\begin{array}{l}\text { Houtproductie } \\
\text { Nederlands bos } \\
\text { Boomsoortverdeling, } \\
\text { naar aandeel en } \\
\text { oppervlak } \\
\text { Staande voorraad, } \\
\text { bijgroei en kap }\end{array}$ \\
\hline Niet-drinkwater & $\begin{array}{l}\text { Levering uit ecosystemen in NL tov de huidige vraag }=59 \% \text {, levering uit } \\
\text { ecosystemen buitenland tov de huidige vraag }=0 \% \text {. Relatieve bijdrage van } \\
\text { ecosystemen: natuurgebied } 86 \% \text {, agrarisch gebied } 14 \% \text {, urbaan gebied } \\
0 \%\end{array}$ & $\begin{array}{l}\text { Waterbalans } \\
\text { Waterwinning en } \\
\text { watergebruik } \\
\text { Ruimtegebruik } \\
\text { openbare } \\
\text { watervoorziening }\end{array}$ \\
\hline Energie & $\begin{array}{l}\text { Levering uit ecosystemen in NL tov de huidige vraag = circa } 1 \% \text {, levering } \\
\text { uit ecosystemen buitenland tov de huidige vraag = circa } 2 \% . \text { Relatieve } \\
\text { bijdrage van ecosystemen: natuurgebied } 8 \% \text {, agrarisch gebied } 92 \% \text {, } \\
\text { urbaan gebied - } \% \text { (onbekend) }\end{array}$ & $\begin{array}{l}\text { Herkomst biomassa } \\
\text { energiedoeleinden } \\
\text { Eindverbruik biomassa }\end{array}$ \\
\hline Luchtzuivering & $\begin{array}{l}\text { de graadmeter is niet uitgeweekt omdat het veel grote onzekerheden } \\
\text { bevat die niet gekwantificeerd zijn. }\end{array}$ & - \\
\hline Erosiebestrijding & $\begin{array}{l}\text { Levering uit ecosystemen in NL ten opzichte van de huidige vraag }=6 \% \text {, } \\
\text { levering uit ecosystemen buitenland ten opzichte van de huidige vraag= } \\
0 \% \text {. Relatieve bijdrage van ecosystemen: natuurgebied } 100 \% \text {, agrarisch } \\
\text { gebied } 0 \% \text {, urbaan gebied } 0 \%\end{array}$ & $\begin{array}{l}\text { Bodemgebruik en } \\
\text { gebieden met } \\
\text { hellingen, gevoeligheid } \\
\text { verstuiving }\end{array}$ \\
\hline Waterberging & $\begin{array}{l}\text { Levering uit ecosystemen in NL ten opzichte van de huidige vraag }=33 \% \text {, } \\
\text { levering uit ecosystemen buitenland ten opzichte van de huidige vraag= } \\
0 \% \text {. Relatieve bijdrage van ecosystemen: natuurgebied } 25 \% \text {, agrarisch } \\
\text { gebied } 75 \% \text {, urbaan gebied } 0 \%\end{array}$ & $\begin{array}{l}\mathrm{M}^{3} \text { water dat } \\
\text { vastgehouden kan } \\
\text { worden, uitgesplitst } \\
\text { per grondsoort }\end{array}$ \\
\hline Kustbescherming & $\begin{array}{l}\text { Levering uit ecosystemen in NL ten opzichte van de huidige vraag }=21 \% \text {, } \\
\text { levering uit ecosystemen buitenland ten opzichte van de huidige vraag= } \\
0 \% \text {. Relatieve bijdrage van ecosystemen: natuurgebied } 100 \% \text {, agrarisch } \\
\text { gebied } 0 \% \text {, urbaan gebied } 0 \%\end{array}$ & $\begin{array}{l}\text { Areaal kwelderzones } \\
\text { Waddenzee, schorren } \\
\text { Zuidwestelijke delta, } \\
\text { slikken en platen } \\
\text { Oosterschelde }\end{array}$ \\
\hline Bestuiving & $\begin{array}{l}\text { Levering dienst uit ecosystemen in NL ten opzichte van de huidige vraag= } \\
8 \% \text {, levering dienst uit ecosystemen buitenland ten opzichte van de } \\
\text { huidige vraag= } 0 \% . \text { Relatieve bijdrage van ecosystemen: natuurgebied } \\
76 \% \text {, agrarisch gebied - } \% \text { (niet meegenomen in totaal), urbaan gebied } \\
24 \%\end{array}$ & $\begin{array}{l}\text { Areaal } \\
\text { bestuivingsafhankelijke } \\
\text { gewassen }\end{array}$ \\
\hline
\end{tabular}


Plaagonderdrukking Levering uit ecosystemen in NL ten opzichte van de huidige vraag $=15 \%$, levering uit ecosystemen buitenland ten opzichte van de huidige vraag=

Areaal plaaggevoelige $0 \%$. Relatieve bijdrage van ecosystemen: natuurgebied $72 \%$, agrarisch gewassen

gebied - \% (niet meegenomen in totaal), urbaan gebied $28 \%$

Areaal

landschapselementen

Bodemvruchtbaarheid Levering uit ecosystemen in NL ten opzichte van de huidige vraag $=57 \%$, Agrarisch grondgebruik levering uit ecosystemen buitenland ten opzichte van de huidige vraag = naar landbouwvorm en niet te kwantificeren. Relatieve bijdrage van ecosystemen: natuurgebied opbrengstdepressie $0 \%$, agrarisch gebied $100 \%$, urbaan gebied $0 \%$

Waterzuivering Levering uit ecosystemen in NL ten opzichte van de huidige vraag = 13\%, Nog geen graadmeter levering uit ecosystemen buitenland ten opzichte van de huidige vraag $=$ niet te kwantificeren. Relatieve bijdrage van ecosystemen: natuurgebied $35 \%$, agrarisch gebied $51 \%$, urbaan gebied

$14 \%$

Koolstofvastlegging Levering uit ecosystemen in NL ten opzichte van de huidige vraag $=0 \%(-$
$1,2 \%$ extra emissie ten opzichte van de totale uitstoot), levering uit Koolstofvastlegging en emissies uit ecosystemen buitenland ten opzichte van de huidige vraag $=0 \%$. Relatieve natuurtypen bijdrage van ecosystemen: natuurgebied $100 \%$, agrarisch gebied $0 \%$, Areaal bos urbaan gebied $0 \%$

Verkoeling in de stad Levering uit ecosystemen in NL ten opzichte van de huidige vraag $=14 \%$, Omvang groen in stad levering uit ecosystemen buitenland ten opzichte van de huidige vraag $=\quad$ (nog geen $0 \%$. Relatieve bijdrage van ecosystemen: natuurgebied $0 \%$, agrarisch graadmeter) gebied $0 \%$, urbaan gebied $100 \%$

Groene recreatie in leefomgeving Levering uit ecosystemen in NL ten opzichte van de huidige vraag $=68 \%$, levering uit ecosystemen buitenland ten opzichte van de huidige vraag $=$ $0 \%$. Relatieve bijdrage van ecosystemen: natuurgebied $51 \%$, agrarisch gebied $18 \%$, urbaan gebied $31 \%$ (recreatieve capaciteit)

\section{Gebieden met} recreatietekorten Belevingswaarde (aantrekkelijkheid landschap) Groene activiteiten Afstanden tot recreatiegebieden

Symboolwaarde natuur Levering uit ecosystemen in NL ten opzichte van de huidige vraag $=15 \%$, levering uit ecosystemen buitenland ten opzichte van de huidige vraag= $0 \%$. Relatieve bijdrage van ecosystemen: natuurgebied $75 \%$, agrarisch gebied $20 \%$, urbaan gebied $5 \%$

Natuurlijk erfgoed
Levering uit ecosystemen in NL ten opzichte van de huidige vraag $=61 \%$, levering uit ecosystemen buitenland ten opzichte van de huidige vraag= $0 \%$. Relatieve bijdrage van ecosystemen: natuurgebied $62 \%$, agrarisch gebied $26 \%$, urbaan gebied $12 \%$ 
Wageningen Economic Research Postbus 29703

2502 LS Den Haag

T 0703358330

Ecommunications.ssg@wur.nl

www. wur.nl/economic-research

Wageningen Economic Research RAPPORT

2016-077
De missie van Wageningen University \& Research is 'To explore the potential of nature to improve the quality of life'. Binnen Wageningen University \& Research bundelen Wageningen University en gespecialiseerde onderzoeksinstituten van Stichting Wageningen Research hun krachten om bij te dragen aan de oplossing van belangrijke vragen in het domein van gezonde voeding en leefomgeving. Met ongeveer 30 vestigingen, 5.000 medewerkers en 10.000 studenten behoort Wageningen University \& Research wereldwijd tot de aansprekende kennisinstellingen binnen haar domein. De integrale benadering van de vraagstukken en de samenwerking tussen verschillende disciplines vormen het hart van de unieke Wageningen aanpak. 



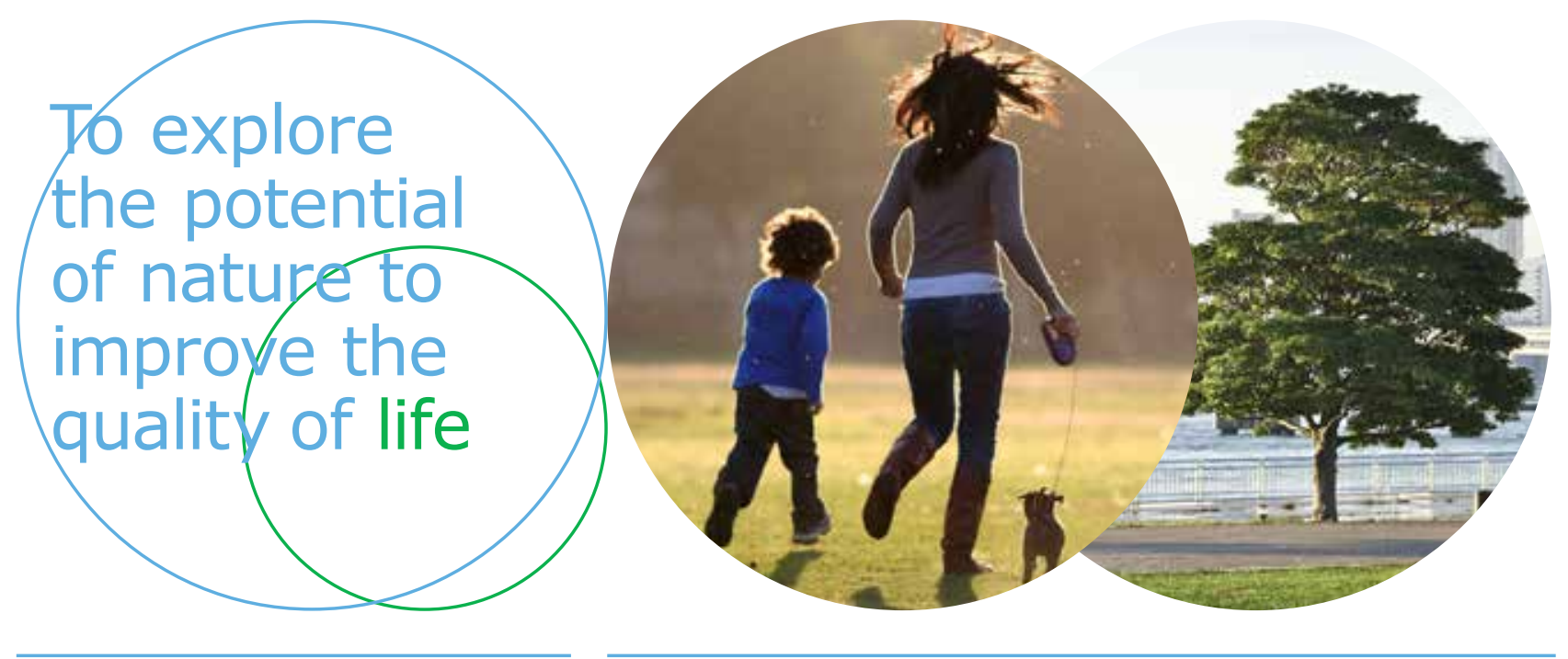

Wageningen Economic Research Postbus 29703

2502 LS Den Haag

E communications.ssg@wur.nl

$\mathrm{T}+31(0) 703358330$

www.wur.nl/economic-research

Rapport 2016-077

ISBN 978-94-6343-033-3
De missie van Wageningen University \& Research is 'To explore the potential of nature to improve the quality of life'. Binnen Wageningen University \& Research bundelen Wageningen University en gespecialiseerde onderzoeksinstituten van Stichting Wageningen Research hun krachten om bij te dragen aan de oplossing van belangrijke vragen in het domein van gezonde voeding en leefomgeving. Met ongeveer 30 vestigingen, 5.000 medewerkers en 10.000 studenten behoort Wageningen University \& Research wereldwijd tot de aansprekende kennisinstellingen binnen haar domein. De integrale benadering van de vraagstukken en de samenwerking tussen verschillende disciplines vormen het hart van de unieke Wageningen aanpak. 